\title{
Geology of Uranium
}

Deposits in the

\section{Front Range, Colorado}

GEOLOGICAL SURVEY BULLETIN 1159

Prepared partly on behalf of the U.S. Atomic Energy Commission

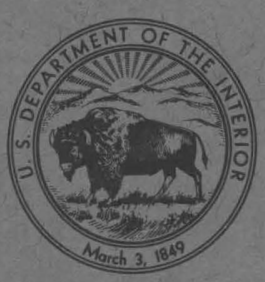




\section{$x^{2}+x^{2}=-x=$}

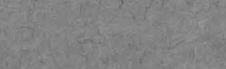

W.

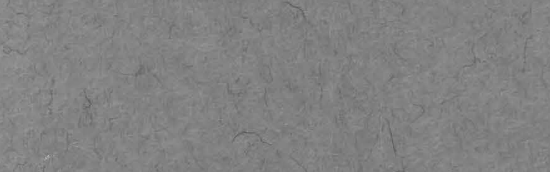

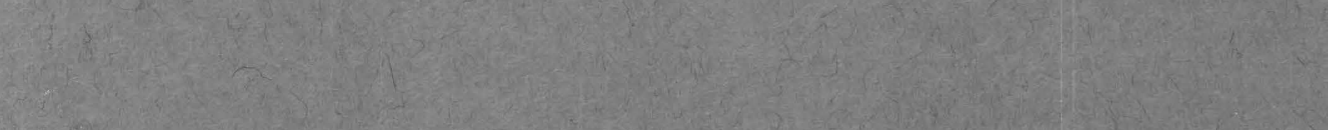

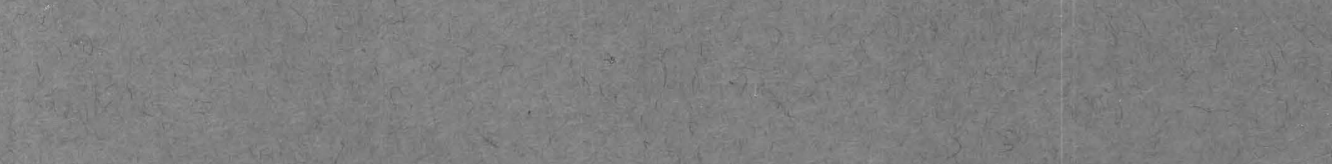

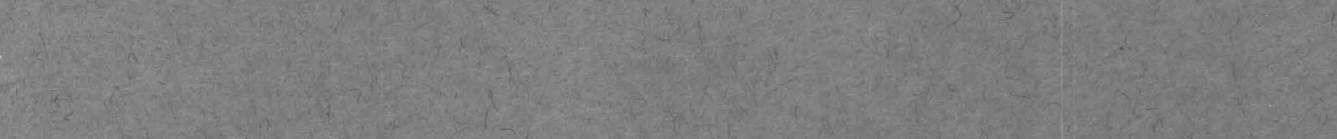

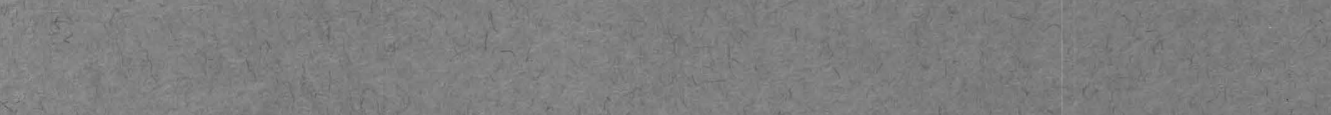
Q

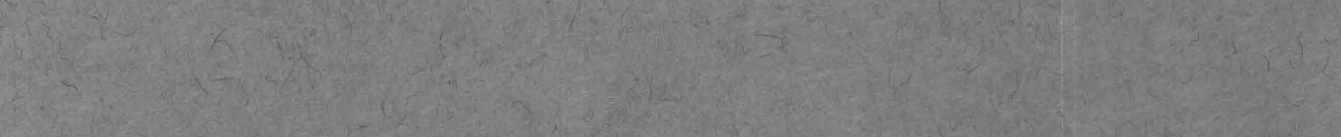

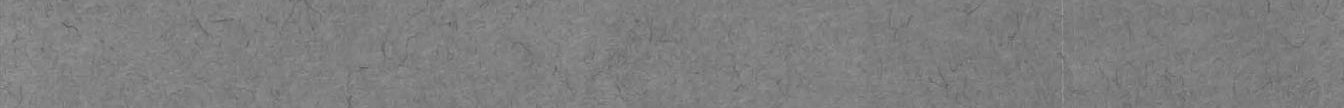

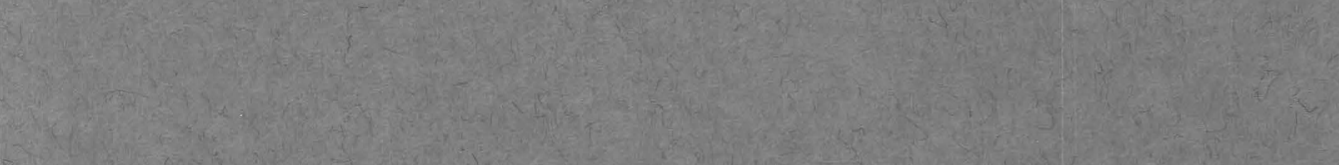

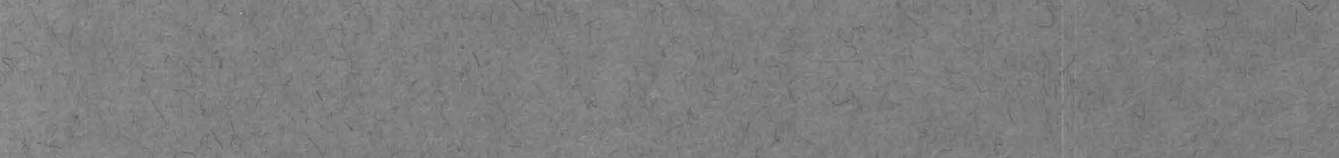
A

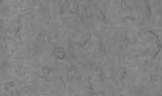

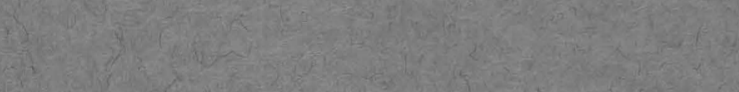
(2) (1.5. (3)

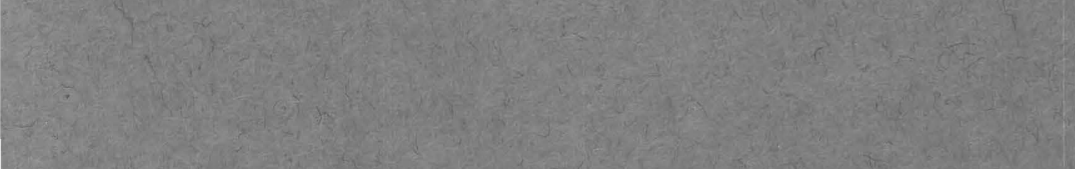

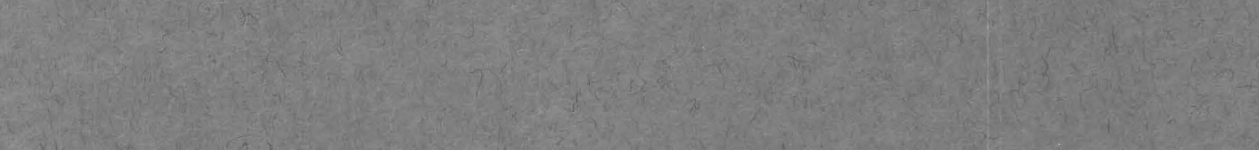

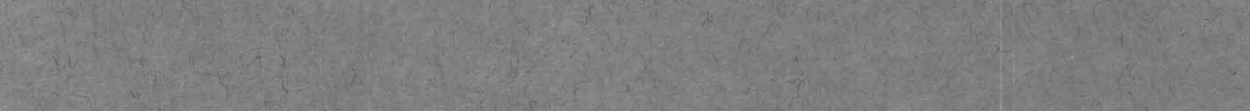

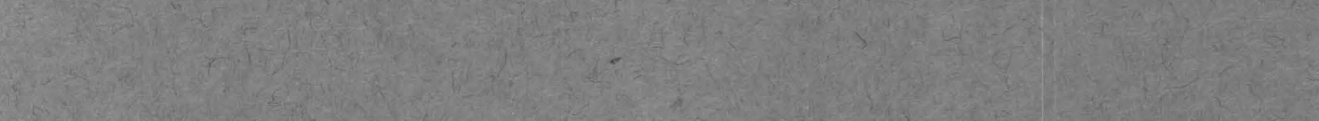
(5)

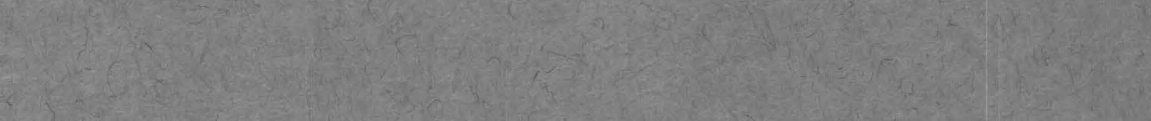




\section{Geology of Uranium}

Deposits in the

\section{Front Range, Colorado}

By P. K. SIMS and D. M. SHERIDAN

With sections

By R. U. KING, F. B. MOORE, D. H. RICHTER and J. D. SCHLOTTMANN

G E O L O G I A L S U R V E Y B U L L E T I N 1159

Prepared partly on behalf of the U.S. Atomic Energy Commission

A summary of the geology of uranium veins in a major productive area

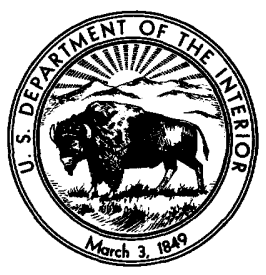


UNITED STATES DEPARTMENT OF THE INTERIOR

STEWART L. UDALL, Secretary

\section{GEOLOGICAL SURVEY}

Thomas B. Nolan, Director

The U.S. Geological Survey Library catalog card for this publication appears after page 116. 


\section{CONTENTS}

Abstract.
Fieldwoduction and acknowledgments
History and production
General geology
Precambrian rocks
Sedimentary rocks of Paleozoic, Mesozoic, and Cenozoic age
Laramide intrusive igneous rocks
Structure of Precambrian rocks.
Faults.

Northwestward-trending faults....................... 12

North-northeastward-trending faults.

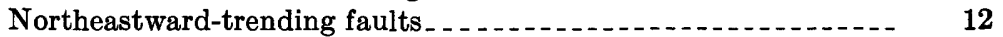

Ore deposits

Uranium deposits

Distribution . .

Mineralogy _._. 17

Minor elements in pitchblende. 18

Minor elements in coffinite. 21

Classification of deposits

Class 1 deposits - uranium-bearing fluorite veins and breccias_._ 22

Class 2 deposits_-uranium-bearing base-metal sulfide veins _... 23

Class 3 deposits_-veins in which uranium minerals are dominant_ $\quad 24$

Paragenesis............. 24

Wallrocks and their alteration._. 36

Localization of deposits... 37

Supergene alteration 39

Oxidation zones of uranium-bearing sulfide veins .

Oxidation zones of veins containing sparse sulfides_.

Age

Regional zoning relative to the mineral belt

Genesis_._.

Future of region

Description of principal miness 47

Boulder County

Jamestown district._._. 54

General features................ 54

Blue Jay mine, by R. U. King

Fair Day mine....... 57

Nations Treasure mine, by R. U. King ............ 61

Victory group........ 62

Gold Hill district..... 63

General features. 63

Black Cloud mine 
Description of principal mines-Continued

Boulder County-Continued

Shirley mine.......... 67

Sisk mine, by F. B. Moore

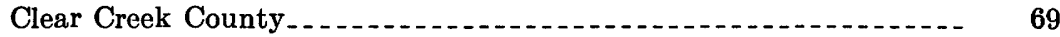

Idaho Springs and adjacent districts . .

Ganeral features........ 69

Almaden mine ...... 71

Other areas. 71

Gold Anchor mine.

Gilpin County

Central City District.... 73

General geology

Carroll mine .

Kirk mine . .

Nortb Gilpin County district._._. 77

Other areas. 78

Jefferson County

Ralston Buttes district.

General geology

Economic geology

Schwartzwalder mine

Other mines.

Idledale district.

General features. 94

Foothills mine, by J. D. Schlottmann $\ldots \ldots$

Grapevine mine, by R. U. King

Other areas............ 99

Black Knight and Billikin lodes, by F. B. Moore

Four Corners uranium mine, by D. H. Richter. . . . . 102

Mann No. 1 mine, by D. H. Richter.

Old Leyden coal mine.

Literature cited . .

Index............. 113

\section{ILLUSTRATIONS}

[Plates are in pocket]

Plate 1. Generalized geologic map of the central part of the Front Range and adjacent areas of Colorado.

2. Geologic map of upper workings, Fair Day mine.

3. Geologic map of the Shirley mine.

4. Geologic maps and sections of the Gold Anchor mine.

5. Geologic sketch map and sections of the Four Corners-Mann No. 1 mine area. 
Figure 1. Map of the Front Range.

2. Map of the central part of Front Range. 16

3-11. Photomicrograph of a polished section of -

3. Colloform pitchblende from the J. P. Whitney mine, Central City district....................

4. Pitchblende ore from the Jo Reynolds mine, Lawson area; Clear Creek County...........-

5. Pitchblende ore from the Mena mine, Ralston Buttes district, Jefferson County.............

6, 7. Ore from the Fair Day mine, Jamestown district_ 28,29 8-10. Coffinite-pitchblende ore from the Fair Day mine, Jamestown district. ............... 30, 31, 32

11. Ore from the Fair Day mine, Jamestown district_ 33

12. Camera lucida drawing of pitchblende-bearing ore from the Mena mine, Ralston Buttes district, Jefferson County --

13. Paragenetic sequence of minerals in the Únion Pacific

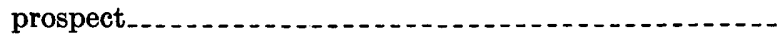

14. Geologic sketch map of the Jamestown district.........

15. Geologic map of the Nations Treasure mine...........

16. Geologic map of part of the third level, Black Cloud mine

17. Geologic map of the underground workings, Sisk property-

18. Map of the Idaho Springs and adjacent districts........

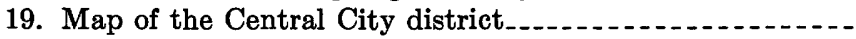

20. Simplified geologic map of the Ralston Buttes district.-.

21. Simplified geologic map of the Schwartzwalder mine area

22. Geologic section of the Schwartzwalder mine...........

23. Sketch map showing the geologic setting of the Idledale district

24. Composite map showing mine woikings, Foothills mine--

25. Geologic map of 186-foot level, Foothills mine

26. Geologic sketch map of the Grapevine mine

\section{TABLES}

TABLE 1. Uranium production from Boulder, Clear Creek, Gilpin, and Jefferson Counties, Front Range, Colo., 1871-1960.

2. Uranium minerals identified from vein deposits in the

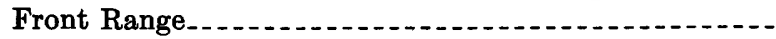

3. Semiquantitative spectrographic analyses of pitchblende concentrates from veins in the central Front Range....

4. Quantitative spectrochemical analyses of coffinite from Fair Day and Copper King mines, Front Range.....-.

5. Dominant wallrocks of uranium deposits in Precambrian terranes. . . . . . . . . .

6. Uranium vein deposits in Boulder County, Colo........

7. Uranium vein deposits in Jefferson County, Colo

8. Uranium production from the Ralston Buttes district, Jefferson County, Colo., 1953-60_.................

9. Uranium production from the Idledale district, Jefferson County, Colo., 1955-60.

10. Uranium production from the Four Corners and Mann No 1 mines, Jefferson County, Colo., 1955-60......- 


\title{
GEOLOGY OF URANIUM DEPOSITS IN THE FRONT RANGE, COLORADO
}

\author{
By P. K. Sims and D. M. Sheridan
}

\begin{abstract}
The Colorado Front Range, one of the principal regions of uranium vein deposits in the United States, has yielded primary black uranium ores intermittently since 1871. The production was small and sporadic during most of this period, but it was increased greatly in the 1950's, after the discovery of several new deposits. The early production was almost entirely from the Central City district, in Gilpin County. Most of the new finds, which now yield the bulk of the output, are in Jefferson County in an area not previously thought to contain commercially important metal deposits. The total output of uranium from the Front Range through 1960 was about $1,513,300$ pounds of $\mathrm{U}_{3} \mathrm{O}_{8}$ that had an estimated value of at least $\$ 6.3$ million.

The uranium deposits are mostly in the Precambrian crystalline rocks that form the core of the Front Range, but a few are in bordering sedimentary rocks. Most of the deposits and nearly all the producing mines are in the east-central part of the range, either within the Front Range segment of the Colorado mineral belt or in the foothills area southeast of the belt.

The deposits are typically fissure veins in faults. Within the mineral belt, the mineralized faults are discontinuous and form a complex intersecting network. In the foothills area, they are long and persistent and have undergone repeated movements. These faults have been called breccia reefs. The deposits in the mineral belt generally are in sulfide-quartz veins that are chiefly valuable for gold and silver, whereas those in the foothills area are in veins that have a gangue of carbonate minerals and potassic feldspar and are valuable primarily for uranium. In addition, in the Jamestown district of Boulder County, uranium occurs in fluorite veins and breccias.

The uranium minerals are dominantly pitchblende and coffinite but include uranothorite, uraniferous hydrocarbon, and, in the oxidized zone, autunite, torbernite, uranophane, kasolite, bassetite, and rarely other highly colored secondary uranium minerals. Pitchblende, the colloform variety of uraninite, is the principal ore mineral. Coffinite, a uranous silicate, is known from several deposits, mainly in the foothills area. Uranothorite occurs in the fluorite veins and breccias of the Jamestown district, and uraniferous hydrocarbons occur in the vein deposits within the sedimentary rocks and locally elsewhere.

The primary uranium minerals typically occur as fillings, either in openings in the fissure veins or in the interstices of breccias. Generally both pitchblende and coffinite were deposited early in the vein-forming sequence, or at least early in any particular stage of vein filling. They were preceded at places by iron sulfides and gangue. Coffinite is closely associated paragenetically with pitchblende, but commonly replaces it.
\end{abstract}


The uranium ore bodies were localized mainly by structural features that provided open spaces for deposition, such as vein junctions or intersections and deflections in vein fissures. Some bodies associated with the breccia reefs in the foothills area, however, possibly reflect a chemical control by iron-rich and calciumrich wallrocks.

The uranium deposits appear to be arranged zonally with respect to the mineral belt, as indicated both by their distribution and size, and by systematic changes in mineralogy, structure, and texture of the veins or vein minerals. The largest and most valuable ore bodies are marginal to the mineral belt and are of epithermal character. Those within the mineral belt, on the other hand, are of mesothermal character.

Spatial and geochemical relations indicate that all the uranium deposits in the central part of the Front Range were derived from the Laramide magma (or magmas) that characterizes the mineral belt and gave rise to its base- and preciousmetal ores. Presumably, uranium-bearing solutions moved outward from the mineral belt along deeply penetrating, persistent breccia reef faults for distances of several miles, as well as upward within the belt. The environment most favorable for deposition of uranium was a cooler zone peripheral to the mineral belt.

It is probable that the Front Range will continue to be a significant source of uranium ore in future years, and additional deposits of economic importance will doubtless be found. Most of the production and most of the new discoveries can be expected to be in the eastern foothills of the range.

\section{INTRODUCTION}

Uranium deposits in the Colorado Front Range have been under study by the U.S. Geological Survey and other government agencies almost continuously since World War II. The opportunity for study of these deposits has been almost unprecedented, for this period has been one of intensified search for uranium ores, and many new mines, and even new mining districts, have been found. A few of the larger and more significant uranium mining districts have been studied systematically by the Geological Survey, and reports describing them have been published. Other areas, or isolated mines, have not been investigated in the same detail. Nevertheless, a large volume of data concerning them has been accumulated through the work of the Geological Survey, the Defense Minerals Exploration Administration and its successor the Office of Minerals Exploration, and the Atomic Energy Commission. It seems worthwhile at this time to present a summary of this information, and insofar as possible to integrate it with the geologic knowledge gained through the comprehensive studies of the main districts. The central part of the Front Range is emphasized in this report because it contains most of the significant uranium deposits and producing mines.

The Front Range (fig. 1), the easternmost range of the Rocky Mountains in Colorado, is a northward-trending mountainous region about 200 miles long and 30-35 miles wide that extends from the vicinity of Canon City to Wyoming, where it merges with the Laramie 


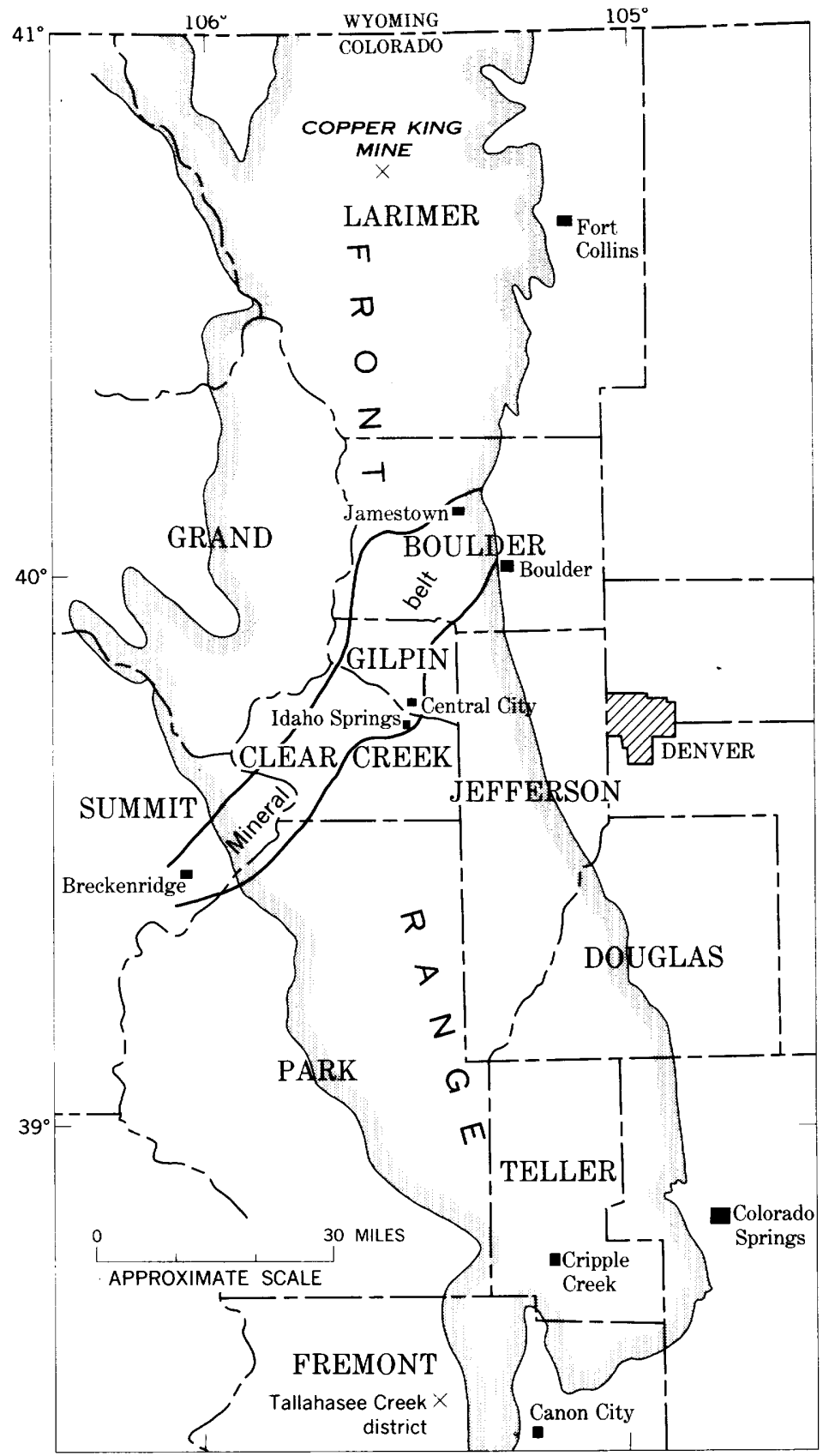

Figure 1.-Map of the Front Range, Colo. 
Range. The crest of the range is at altitudes of $12,000-14,000$ feet. From the crest, the mountain flanks slope steeply to the west but descend more gradually to the east. The area of primary concern to this report lies on the east flank of the range, at altitudes generally between 6,500 and 11,000 feet.

The Front Range has long been famed as an important metalmining area, and it contains several classic mining districts, most of which are described in the well-known publication by Lovering and Goddard (1950). Except for Cripple Creek, which is located at an isolated volcanic center in the southern part of the range, the principal districts lie within the Front Range segment of the Colorado mineral belt (Tweto and Sims, 1963). A remarkable variety of metals has been mined in this segment of the mineral belt. Gold and silver have been the most valuable products but lead, zinc, copper, tungsten, and uranium have been mined also. Gold accounts for far more than 50 percent of the value of the ores, which exceed $\$ 200$ million.

\section{FIELDWORK AND ACKNOWLEDGMENTS}

The investigations on which this report is based began in 1947 and continued through 1959 . The studies were started mainly as a consequence of preliminary work carried on by the Manhattan District Engineer Project as early as 1943 and by the U.S. Geological Survey as early as 1945. From 1947 to 1951 the work consisted largely of reconnaissance investigations for uranium (King and others, 1953; Leonard, 1952) but included detailed mapping and sampling of selected mines (Moore and Butler, 1952) and some geochemical studies (Phair, 1952; Phair and Levine, 1953). This work was aided by earlier studies of uranium deposits in the Front Range, especially in the Central City district by Pearce (1898), Rickard (1913), Moore and Kithil (1913), Alsdorf (1916), Bastin (1915, 1916), and Bastin and Hill (1917), and in the Jamestown district by Goddard and Glass (1940), and Goddard (1946). As an outgrowth of these investigations, detailed studies were started in 1951 in selected areas in the range, as at Caribou (Moore and others, 1957), Central City (Armstrong, 1952), and the Jo Reynolds mine area near Idaho Springs (Harrison and Leonard, 1952), and a year later systematic geologic studies, including areal mapping, were begun in a 50-square mile area in the central part of the Front Range mineral belt, in an area that embraces the Central City, Idaho Springs, and adjacent mining districts. The results of this work, the first comprehensive studies of uranium-bearing deposits in the Front Range, have been published (Wells and Harrison, 1954; Sims and Tooker, 1956; Sims and others, 1963). Also as an outgrowth of the uranium studies, other reports have been prepared on the Central City district (Sims and others, 1955; Sims, 1956a; Drake, 
1957; Sims, Drake, and Tooker, 1963), the Freeland-Lamartine district (Harrison and Wells, 1956; Harrison, 1955), and the Chicago Creek area (Harrison and Wells, 1959), and reports on the Idaho Springs and Lawson-Dumont-Fall River districts are in preparation. In 1949, after a prospector had discovered important uranium deposits in northwestern Jefferson County, the U.S. Geological Survey began investigations in the Ralston Buttes quadrangle. During the early phases of this work several uranium deposits were discovered by Survey geologists (Adams and others, 1953; Adams and Stugard, $1956 \mathrm{a}, 1956 \mathrm{~b}, 1956 \mathrm{c})$. In 1953, systematic areal mapping was started in the Ralston Buttes quadrangle and detailed studies of all the known uranium deposits were undertaken; the preliminary results of this work have been published (Sheridan, 1956; Sheridan and others, 1958), and a more detailed report is being prepared by Sheridan, Maxwell, Albee, and Van Horn. During the succeeding 4 years, intermittent studies of scattered mines throughout the Front Range were made by the Geological Survey and other Federal agencies. Although these studies were intended as evaluations of uranium ore reserves and potential rather than exhaustive investigations, they have yielded many valuable geologic data.

The investigations by the U.S. Geological Survey were sponsored largely by the Division of Raw Materials of the U.S. Atomic Energy Commission.

The specific contributions of the many who aided in the collection of data on which this report is based are indicated in the publications listed above and in the text of this report, and are gratefully acknowledged here even though they are not listed in detail. Completion of the text in its present form is, to a large extent, due to the assistance of Ogden Tweto. The mining people throughout the region cooperated fully in every way, and many individuals provided pertinent information on the history and ore occurrences in the mines.

\section{HISTORY AND PRODUCTION}

Although the Front Range has been a source of primary black uranium ores for nearly a century, most of the production has come within the past 10 years, since the discovery of several moderately large deposits along the eastern flank of the range. The total output of uranium from the Front Range through 1960 was about 107,200 tons of crude ore that contained about $1,513,300$ pounds of $\mathrm{U}_{3} \mathrm{O}_{8}$. The value of this yield is not accurately known, but it is at least $\$ 6.3$ million. Deposits in Boulder, Clear Creek, Gilpin, and Jefferson Counties in the central part of the range account for nearly all of the production, having yielded about 106,400 tons of crude ore that contained about $1,509,300$ pounds of $\mathrm{U}_{3} \mathrm{O}_{8}$ (table 1 ). The remainder 
of the production, so far as known, has been from Larimer County. The important deposits of the Tallahassee district, in Fremont County west of Canon City, at the south margin of the Front Range (fig. 1), are not discussed in this report. These deposits have been described briefly by R. J. Wright and D. L. Everhart (Del Rio, 1960).

TABLE 1.-Uranium production from Boulder, Clear Creek, Gilpin, and Jefferson Counties, Front Range, Colo., 1871-1960

[Compiled from records of U.S. Bur. Mines; Div. Raw Materials, U.S. Atomic Energy Comm.; Office of Minerals Explor. and report by Sims and others (1963)]

\begin{tabular}{|c|c|c|c|c|c|c|c|c|}
\hline \multirow[b]{2}{*}{ Year } & \multicolumn{2}{|c|}{ Boulder County } & \multicolumn{2}{|c|}{ Clear Creek County } & \multicolumn{2}{|c|}{ Gilpin County } & \multicolumn{2}{|c|}{ Jefferson County } \\
\hline & $\begin{array}{c}\text { Ore } \\
\text { shipped } \\
\text { (short } \\
\text { tons) }\end{array}$ & $\begin{array}{c}\mathrm{U}_{3} \mathrm{O}_{8} \\
\text { (pounds) }\end{array}$ & $\begin{array}{c}\text { Ore } \\
\text { shipped } \\
\text { (short } \\
\text { tons) }\end{array}$ & $\begin{array}{c}\mathrm{U}_{3} \mathrm{O}_{8} \\
\text { (pounds) }\end{array}$ & $\begin{array}{c}\text { Ore } \\
\text { shipped } \\
\text { (short } \\
\text { tons) }\end{array}$ & $\begin{array}{c}\mathrm{U}_{3} \mathrm{O}_{8} \\
\text { (pounds) }\end{array}$ & $\begin{array}{c}\text { Ore } \\
\text { shipped } \\
\text { (short } \\
\text { tons) }\end{array}$ & $\begin{array}{c}\mathrm{U}_{3} \mathrm{O}_{8} \\
\text { (pounds) }\end{array}$ \\
\hline \multirow{9}{*}{$\begin{array}{l}1871-1909 \\
1910-49 \\
1950 \\
1951 \\
1952 \\
1953 \\
1954 \\
19556 \\
1957 \\
1958 \\
1959\end{array}$} & 2.5 & 375. & 8.0 & 11,520 & $\begin{array}{r}254.5 \\
70.1\end{array}$ & $\begin{array}{l}95,700 \\
15,057\end{array}$ & & \\
\hline & 2.0 & 0.10. & 0.0 & 11,020 & & & & \\
\hline & - & --- & -- & & $\ldots$ & & & \\
\hline & ........ & & 1.5 & 3.09 & 17.4 & 800 & 51.3 & $1,354.06$ \\
\hline & & & (1) & & 13.0 & 133 & 691.0 & $9,476.25$ \\
\hline & 189.5 & $1,476.67$ & (2) & & 22.6 & 287.67 & $1,718.5$ & $16,327.38$ \\
\hline & & .00 & 97.0 & 204.33 & & & $\begin{array}{l}10,500.2 \\
16,702.5\end{array}$ & $\begin{array}{l}148,004.97 \\
221,649.05\end{array}$ \\
\hline & $2,246.0$ & 21,249 & & & & & $17,608.0$ & 247,893 \\
\hline & $\begin{array}{r}882.0 \\
4,131.0\end{array}$ & $\begin{array}{r}7,373 \\
52,181\end{array}$ & & & $\begin{array}{l}36.0 \\
13.0\end{array}$ & $\begin{array}{l}73 \\
19\end{array}$ & 20,0 & $\begin{array}{l}332,520 \\
323,380\end{array}$ \\
\hline Total & $7,996.5$ & $84,400.25$ & 106.5 & $11,727.42$ & 426.6 & $112,069.67$ & $97,853.5$ & $1,301,104.71$ \\
\hline
\end{tabular}

1 Excludes 51.5 tons of uraninite-bearing pegmatite ore shipped from Highlander claim, Idaho Springs district, that contained $253.6 \mathrm{lb} \mathrm{U}_{3} \mathrm{O}_{8}$.

2 Excludes ore shipment reported from the Lone Star No. 1 Mine 4 miles east of Idaho Springs, presumably uranium-bearing pegmatite, 369.7 tons that contained $1,693.69 \mathrm{lb} \mathrm{U}_{3} \mathrm{O}_{8}$.

${ }_{3}$ Excludes ore shipment reported from the Lone Star No. 1 mine 4 miles east of Idaho Springs, presumably

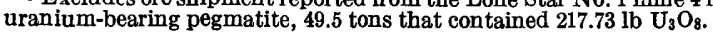

The first discovery of pitchblende in the United States was made at Central City in 1871, when Pearce (1898) recognized the mineral on the dump of the Wood gold mine on Quartz Hill. For many years thereafter the Central City district sporadically yielded small quantities of pitchblende ore of remarkably high grade, mostly as a byproduct of the mining of gold ores. The uranium ore came mainly from two mines, the Wood and the Kirk, both on Quartz Hill (Sims and others, 1963). Much of this ore was sold in France as a source of radium, but some was sold for other purposes-as specimens, for experimental use, or to commercial consumers. Since World War I, the production from Central City and adjacent areas has been negligible.

A few years after the discovery at Central City, uranium was recognized in the Old Leyden coal mine (Berthoud, 1875) in Jefferson County, east of the foot of the range. Shortly afterward (Mining and Sci. Press, 1884), pitchblende was reported to have been found in Jefferson County, but the location was not specified. 
The intensive search for uranium ore during and subsequent to World War II led to the discovery of many deposits, both in areas of previously known deposits and in areas where no valuable ore deposits of any type had been recognized. The discoveries were widely scattered, but most of the deposits which later were developed as moderately large mines were found in the east-central part of the range, in the foothills area; accordingly, this area has attained the largest production and has the greatest potential for future yield. The first and most important discovery in this area was the Schwartzwalder mine in the Ralston Buttes district (Adams and others, 1953, p. 13; Sheridan, 1956, p. 133-136). From 1953 through 1960, this mine yielded about 77,660 tons of ore that contained about 1,188,000 lbs. of $\mathrm{U}_{3} \mathrm{O}_{8}$, which amounts to about three-fourths of the total production of $\mathrm{U}_{3} \mathrm{O}_{8}$ from the Front Range. Other important discoveries were made during the following few years in the Idledale district, Jefferson County, and in the Jamestown district, Boulder County.

A few significant discoveries have been made in other parts of the Front Range, but only one deposit has yielded substantial quantities of ore. The Copper King mine, discovered in Larimer County in 1949, was operated from 1951 to 1953 and yielded 652 tons of ore that had an average grade of 0.28 percent $\mathrm{U}_{3} \mathrm{O}_{8}$ (Sims and others, 1958).

\section{GENERAL GEOLOGY}

The Front Range consists almost entirely of Precambrian crystalline rocks; which form the core of a large flat-topped anticlinal arch (pl. 1). Sedimentary rocks of Paleozoic and Mesozoic age turn up on the flanks of the arch, and all except the Cretaceous formations thin and wedge out against the core. At about midlength, the range is crossed by the Front Range mineral belt, a narrow northeastwardtrending belt characterized by porphyritic igneous rocks and associated ore deposits formed during the Laramide orogeny (Late Cretaceous and early Tertiary). Structure of the body of the range is largely of Precambrian origin, but northeastward-trending fissures of Laramide age characterize the mineral belt. The margins of the range are geologically complex. South of the mineral belt, the eastern border is marked by large faults, most of which are steep. North of the mineral belt, the eastern border is marked in the flanking sedimentary rocks by echelon folds of a northwest trend, some of which are broken by longitudinal faults. The west side of the range is characterized by overthrust faults of a north-northwest trend arranged en echelon in a zone that trends northward through much of the length of the range. These faults carry crystalline rocks of the core westward over the flanking sedimentary rocks. 


\section{PRECAMBRIAN ROCKS}

The Precambrian core of the Front Range consists of several types of metamorphic and igneous rocks. The oldest of these-metamorphic rocks predominantly of sedimentary origin - are mainly biotite gneisses and schist. Biotite-quartz-plagioclase gneiss, sillimanitic biotitequartz gneiss, and quartz-mica schist are most abundant and widespread, but other varieties, especially garnetiferous biotite gneiss, garnetiferous sillimanite-biotite gneiss, sillimanitic quartz-mica schist, and graphitic biotite gneiss occur in small bodies. Hornblende gneiss, calc-silicate gneiss, and amphibolite are neither as widespread nor as abundant as biotite gneiss, but they form many thin layers in the east-central part of the range, east of Idaho Springs, as well as large bodies, in the west-central part, from Fraser southward to Montezuma and beyond. A granitic gneiss-microcline-quartz-plagioclase-biotite gneiss - is interlayered with the other metasedimentary gneisses in the central part of the range; it was formerly considered an orthogneiss (Bastin and Hill, 1917, p. 30-32 ; Lovering and Goddard, 1950, p. 2324) but is now classed as a paragneiss (Sims, Drake, and Tooker, 1963; Moench and others, 1962). In the Central City-Idaho Springs area (Sims, 1960), this gneiss, hereafter referred to as microcline gneiss, forms several layers a few hundred feet to as much as 3,000 feet thick that are intercalated with layers of biotite gneiss equally as thick. In the Coal Creek area, about midway between Golden and Boulder, the biotitic gneisses give way to a thick sequence of quartzite and schist (Wells and others 1961).

The gneisses and schists are locally migmatized and are intruded by three principal types of granitic rocks-Boulder Creek Granite, Silver Plume Granite, and Pikes Peak Granite-as classed by Lovering and Goddard (1950) and by lesser bodies of other igneous rocks. Most of the intrusive bodies are small, either stocks or dikes, but a few, especially the large body of Pikes Peak Granite in the southern part of the range, are of batholithic dimensions. The granitic rocks are not distinguished separately on plate 1 but are shown on maps in other reports (Lovering and Goddard, 1950, pl. 2).

In the central part of the range, Boulder Creek and Silver Plume Granites are the principal Precambrian intrusive rocks. Boulder Creek Granite ranges from quartz diorite to granite in composition, but the most abundant phases are granodiorite or quartz monzonite. Where studied in detail near Idaho Springs (Harrison and Wells, 1959), the rock clearly is syntectonic; it was intruded during the period of folding that accompanied the plastic deformation of the metasedimentary gneisses. The Silver Plume Granite forms small stocks and locally abundant dikes. This rock, a biotite-muscovite granite, is late syntectonic, at least where studied in the Central City-Idaho 
Springs area (Moench and others, 1962; Harrison and Wells, 1956, 1959). At places small bodies of quartz diorite and associated hornblendite intrude the metamorphic rocks and less commonly the Boulder Creek Granite. These rocks are younger than the Boulder Creek Granite, but apparently also syntectonic, for they are generally conformable and locally metamorphosed.

\section{SEDIMENTARY ROCKS OF PAIEOZOIC, MESOZOIC, AND CENOZOIC $\triangle G E$}

Sedimentary rocks of Paleozoic and younger age overlap the Precambrian core of the Front Range on both the east and the west flanks. The Paleozoic and Mesozoic rocks dip steeply away from the core and in places disappear beneath formations of Tertiary and Quaternary age. In the area here considered, uranium deposits are known to occur in sedimentary rocks only on the east flank of the range, in formations of Cretaceous age. For this reason the following summary is brief and concerns only the eastern flank. For a more detailed description of the sedimentary rocks on the eastern flank the reader is referred to reports by Lee (1927), Lovering and Goddard (1950), Boos and Boos (1957), Waagé (1955), and Van Horn (1957).

The Front Range was a strong positive element through much of the Paleozoic and Mesozoic Eras, as indicated by the way in which formations older than the Cretaceous thin and overlap against the crystalline core. Strata of Pennsylvanian age rest on Precambrian rocks along the eastern border of the range from Wyoming southward to Perry Park, 30 miles south of Denver. Farther south, rocks of Mississippian, Ordovician, and Cambrian age appear beneath the Pennsylvanian.

The sedimentary formations on the eastern flank can be grouped into four major lithologic units, in a manner adopted by Boos and Boos (1957, p. 2618-2634). A basal unit consists of marine limestones and sandstones, Cambrian to Mississippian in age, that are only a few hundred feet thick and are confined to the inner foothills belt along the southern third of the range. The second unit, consisting of terrestrial and littoral arkose, red shale, and sandstone formations of late Paleozoic and early Mesozoic age, attains an aggregate thickness of about a mile. It lies unconformably upon, and overlaps, the lower marine unit and along the northern two-thirds of the range, lies directly on the Precambrian rocks. The third and thickest unit comprises marine formations of Cretaceous age; it makes up the outer part of the foothills belt and fills basins that flank the range. This unit consists, from oldest to youngest, of the Dakota Group, Graneros Shale, Greenhorn Limestone, Carlile Shale, Niobrara Formation, Pierre Shale, Fox Hills Sandstone, and Laramie Formation. The 
fourth unit, consisting of continental deposits of Late Cretaceous and Tertiary age, disconformably overlies the older rocks. The oldest strata of this unit, the Arapahoe and Denver Formations, grade from quartzose sandstones and claystones upward into tuffaceous sediments, and near Golden, the Denver Formation contains interbedded latitic lava flows (Van Horn, 1957). According to Lovering and Goddard (1950, p. 40), the Arapahoe and Denver Formations were derived from the Front Range while it was being elevated early in the Laramide revolution.

\section{LARAMIDE INTRUSIVE IGNEOUS ROCKS}

Igneous rocks intruded during the Laramide orogeny are characteristic of the Front Range mineral belt and occur also in a narrow northeastward-trending belt in the northern part of the range and sporadically in areas adjacent to the mineral belt. The intrusive rocks are typically porphyritic, indicating emplacement at relatively shallow depths. They are related temporally and probably also genetically to extrusive rocks interbedded in the Denver Formation and its equivalents on the eastern and western flanks of the range (Lovering and Goddard, 1950).

The Laramide intrusives vary in composition from gabbro to silicic granite but are dominantly monzonite or quartz monzonite (Lovering and Goddard, 1938, 1950, p. 43-50; Wells, 1960). The intrusives also vary in form and to a lesser extent in texture. The older rocks tend to occur as irregular, pluglike plutons as much as several square miles in area and are moderately even grained; the younger rocks typically form narrow dikes, as much as several miles in length, and tend to be strongly porphyritic.

Within the central and northeast part of the mineral belt-the region of especial interest in this report-the intrusive rocks range in composition from granodiorite to alaskite, and form a rather welldefined sequence (Lovering and Goddard, 1950, p. 45). In the central part of the belt the succession has been determined by Wells (1960) to consist, from oldest to youngest, of a light-colored granodiorite group, a quartz monzonite group, and a bostonite group; a subordinate series of intrusives ranging from an older hornblende granodiorite to a younger biotite-quartz latite was emplaced in one part of the area. Phair (1952) and Wells (1960) showed that these rocks are unusually radioactive; that successively younger phases of the sequence are enriched in uranium, thorium, and zirconium compared to the older phases; and that enrichment in uranium and thorium culminated in quartz bostonite porphyry, an alkalic rock poor in calcium and magnesium. The quartz bostonite porphyry in the vicinity of Central City contains as much as 0.024 percent equivalent uranium 
and 0.017 percent uranium; the thorium content of the rocks is as much as 0.048 percent.

\section{STRUCTURE OF PRECAMBRIAN ROCKS}

The Precambrian crystalline rocks are complexly folded and, locally, strongly cataclasized as a result of at least two major episodes of Precambrian deformation. Complex folds of diverse trends, which define the gross distribution of the rcck units and determine local trends of foliation of the metamorphic rocks, were formed during plastic deformation under high pressure-temperature conditions. In the east-central part of the range (pl. 1), the major folds formed by this deformation have two dominant trends. In an extensive area north and northwest of Idaho Springs, they trend north or northeast and generally are broad and open. East and southeast of Idaho Springs, in contrast, they trend west-northwest or west-southwest and are dominantly tightly compressed and locally closed. The line of demarcation between areas of different structural arrangement is a zone defined by intense cataclasis, which has been called the Idaho Springs-Ralston shear zone (Tweto and Sims, 1963, p. 998). This zone, about $1 \frac{1}{2}$ miles wide, is characterized by northeastward-trending young folds and associated cataclasis. The folds in this zone are superimposed on the older folds of the major regional deformation, and they resulted from deformation under generally lower pressure-temperature conditions than the earlier plastic deformation. Details of the folding in areas in the central part of the range are given in reports by Moench, Harrison, and Sims (1962) and Wells, Sheridan, and Albee $(1961,1964)$.

The Precambrian intrusive rocks in the central part of the range are mainly concordant, at least in gross aspects, and accordingly have a structural arrangement similar to the metamorphic rocks. An exception is the Silver Plume Granite, which forms many thin crosscutting dikes.

\section{FAULTS}

The crystalline core of the Front Range and, locally, the bordering sedimentary rocks are cut by hundreds of faults. Many of these, including those of greatest persistence and displacement are either northwestward-trending faults and breccia reefs or north-northeastward-trending faults. These two sets have long been considered of Laramide age but now are classed as Precambrian in age (Tweto and Sims, 1963, p. 1001) although they underwent extensive movements in the Laramide orogeny. The mineral belt is characterized also by abundant northeastward-trending fractures of Laramide age. These faults, which are the dominant vein fissures of the mining districts in the belt, are generally short and have small displacements. 


\section{NORTHWESTWARD-TRENDING FAULTS}

The northwestward-trending faults and breccia reefs are present throughout the length of the range. They are long and persistent, and some have been traced across the full width of the mineral belt and for many miles on each side. The faults show wide variation in character, and they range from simple fractures to broad shear zones. Most of them have had a complex history of movement. Many show a dominant strike-slip movement of as much as several hundred feet in a leftlateral direction, and, in addition, vertical and oblique movements of smaller magnitude. The strike-slip movements are largely, if not entirely, of Precambrian age, whereas the vertical and oblique movements are probably Laramide in age. A few of the larger and more persistent faults are shown on plate 1. More detailed maps (Lovering and Goddard, 1950, pl. 2; Sims, Drake, and Tooker, 1963, pl. 2; Sheridan and others, 1958) more accurately portray the abundance and pattern of the faults.

Associated with the northwestward-trending faults, and genetically related to them, are low-angle faults (Lovering and Tweto, 1953, p. 31; Sims and others, 1963). These faults dip less than $50^{\circ}$, strike east or within a few degrees of east, and appear to connect between larger and more persistent faults of a northwestward trend.

Within and adjacent to the mineral belt, the northwestward-trending faults and related low-angle faults locally contain dikes of Laramide intrusive rocks. The oldest dikes are quartz monzonite porphyry, which is intermediate in age among the porphyritic intrusives, and some of them have been sheared by younger fault movements.

\section{NORTH-NORTHEASTWARD-TRENDING FAULTS}

Faults that trend north-northeast are particularly common in the central part of the range, along the northwest side of the mineral belt (pl. 1), and a few are known on the eastern flank in the Central City district (Sims and others, 1963) and the Gold Hill district (Goddard, 1940). They resemble the northwestward-trending faults in that they are wide sheared zones that locally contain siliceous breccias or dikes of Laramide porphyritic igneous rocks. Movement along the faults was dominantly strike-slip and as much as a few hundred feet in extent. In the Central City district the north-northeastward-trending faults are younger than the northwestward-trending faults (Sims, Drake, and Tooker, 1963, p. 23).

\section{NORTHEASTWARD-TRENDING FAULTS}

Northeastward-trending faults of small displacement characterize the Front Range mineral belt, but it has not yet been established that they are confined to the belt. They are abundant in all mining districts of the belt and generally contain most of the veins. The pattern 
of these faults or veins fissures, as well as their age relations, varies slightly from district to district. At Gold Hill (Goddard, 1940, p. 123124) and the Boulder County tungsten district (Lovering and Tweto, 1953 , p. 32-33), in the south-central part of Boulder County, the principal vein fissures strike north-northeast or about east-northeast, but some strike nearly east. At Gold Hill, the north-northeastward-trending fissures appear to be earlier than the east-northeastward-trending set (Goddard, 1940, p. 124); both sets have right lateral movement, with displacements generally less than 20 feet. In the Boulder County tungsten district, the two sets of vein fissures are interpreted to have formed essentially contemporaneously (Lovering and Tweto, 1953, p. 33). At Central City, in Gilpin County, three sets of faults trending respectively northeast, east-northeast, and east form a complex meshlike network (Sims, Drake, and Tooker, 1963 , p. 22-23); they developed in the sequence east, east-northeast, and northeast. As in the other districts, displacements are small, rarely more than 20 feet, and dominantly strike-slip. The faults that trend northeast and east-northeast record right-lateral movements, whereas the faults that trend east have left-lateral movements.

Although the northeastward-trending faults are dominantly of Laramide age, as at Central City and adjacent mining districts (Sims and others, 1963), some are clearly older and probably developed initially in the Precambrian.

\section{ORE DEPOSITS}

Although ores of diverse types and ages occur in the Front Range, most deposits and nearly all important mining districts are. in the mineral belt. Noteworthy deposits outside the mineral belt are the gold ores of Tertiary age at Cripple Creek, located at an isolated volcanic center and some of the Laramide uranium deposits east of the mineral belt. Of lesser importance are scattered deposits of Precambrian age, including some of tungsten (Tweto, 1960), and of copper, zinc, and gold (Lovering and Goddard, 1950, p. 63-72).

As commonly defined, the Front Range mineral belt includes the principal metal-mining districts, together with closely clustered small districts, in a narrow northeastward-trending strip of ground that crosses the range at about midlength (Tweto and Sims, 1963, p. 993; Lovering and Goddard, 1950). It is characterized by ore deposits that are related, at least distantly, to intrusive porphyries of Laramide age. The mining districts are localized at intrusive centers marked by an unusual abundance of dikes and small irregular plutons of porphyry.

The ore deposits in the mineral belt typically are veins formed as simple fissure fillings in openings along the various premineralization 
faults. Stockworks are found sporadically, and replacement deposits occur in certain sedimentary rocks in the Breckenridge district (Lovering, 1934). The ore deposits are principally gold-bearing pyrite-quartz veins and silver-bearing galena-sphalerite veins. These veins are present in all the mining districts, but in some they are only of secondary importance. Characteristically, they contain pyrite, chalcopyrite, tetrahedrite-tennantite, sphalerite, and galena in a gangue of quartz locally accompanied by carbonate minerals, barite, and fluorite. Gold telluride veins are also common, especially in the northern part of the Front Range mineral belt. Tungsten veins (Lovering and Tweto, 1953, p. 54) are present in the Boulder County tungsten district but are rare elsewhere, and fluorite deposits are present in the Jamestown district (Goddard, 1946).

In general, the ores have a zonal arrangement around local centers of mineralization within the belt. A central zone of gold-bearing ores is surrounded by a zone of silver-bearing ores in most districts, but significant differences exist from one district to another. The best known and most fully documented example of zoning is the Central City district (Sims, Drake, and Tooker, 1963, p. 38-41; Sims and Barton, 1962). There, a core area of pyrite veins, which locally contain gold, is surrounded by an outer area of dominantly silver-bearing galena-sphalerite veins. An intermediate area contains transitional veins that have characteristics of veins in both the inner and outer zones and, in addition, contain copper. Most of the important ore deposits of the district are in the intermediate zone.

Because the ore deposits of the mineral belt are closely associated geographically and temporally with the Laramide porphyritic igneous rocks, most investigators have concluded that the ores and igneous rocks were derived from a common source. Lovering and Goddard $(1938,1950)$ relate the deposits at different centers of mineralization to specific Laramide igneous rocks of local derivation. More recently, it has been proposed (Sims, Drake, and Tooker, 1963) that the ores at the Central City and adjacent districts were derived mainly from a moderately deep-seated magma chamber that spawned several types of porphyries and in turn yielded the ore deposits. A possible exception, to be discussed in a later chapter of this report, is uranium, some of which appears to have been derived directly from relatively shallow local dikes of quartz bostonite porphyry-the youngest preore intrusive of the Laramide igneous sequence.

\section{URANIUM DEPOSITS}

The uranium deposits of the Front Range are veins that contain pitchblende and, less commonly coffinite. They occur dominantly in the Precambrian crystalline core of the range, either in the mineral 
belt or in an area in the eastern foothills of the range, immediately southeast of the mineral belt. A few deposits occur in the flanking sedimentary rocks also. Most of the deposits of economic significance are in the foothills area.

Uranium-bearing pegmatites are widespread in the Front Range, but none have proved to be valuable commercially for uranium. The largest and those most likely to be of economic importance in the future are simple pegmatites that contain disseminated uraninite in a quartz-feldspar-biotite matrix (Sims and others, 1963). Although many zoned pegmatites in the Front Range are known to contain uraninite and rare-earth minerals (Page, 1950), the uranium minerals are sparse and are in such small bodies that they are unlikely to be recovered except possibly as a byproduct.

\section{DISTRIBUTION}

The know uranium vein deposits occur principally in the central part of the Front Range, where they are concentrated in the north half of the mineral belt-in Boulder, Gilpin, and Clear Creek Counties-and in a large area southeast of the belt, in Jefferson County. The locations of producing mines and of deposits of exceptional geologic interest are shown in figure 2. Deposits in Boulder and Jefferson Counties that contain more than 0.01 percent equivalent uranium (radioactivity) are tabulated in tables 6 and 8 respectively, and several are described in the section on the mines. Deposits in Clear Creek and Gilpin Counties have been tabulated previously (Sims and others, 1963), and a few of them are described briefly in the section on the mines.

All the deposits discussed in this report are in Precambrian rocks except the Old Leyden, Four Corners, and Mann No. 1 mines, which are in Cretaceous sedimentary rocks on the eastern flank of the range.

The uranium deposits in the mineral belt occur within base-metal mining districts, commonly in association with other ores. They are particularly abundant in the Jamestown district, Boulder County, and the Central City district, Gilpin County, but occur sparingly in most of the districts in the northern part of the belt. At Jamestown (fig. 14), deposits are widely dispersed, but most of them are clustered in a narrow zone trending northwestward through the town; a few deposits, as the Fair Day, are on the fringes of the district. At Central City (fig. 19), the deposits also are widely distributed, but a large proportion of them and most of the producing mines are grouped in two major clusters; one of these clusters - a square-mile area at Quartz Hillcontains nearly half of the 59 significant deposits (Sims and others, 1963). 


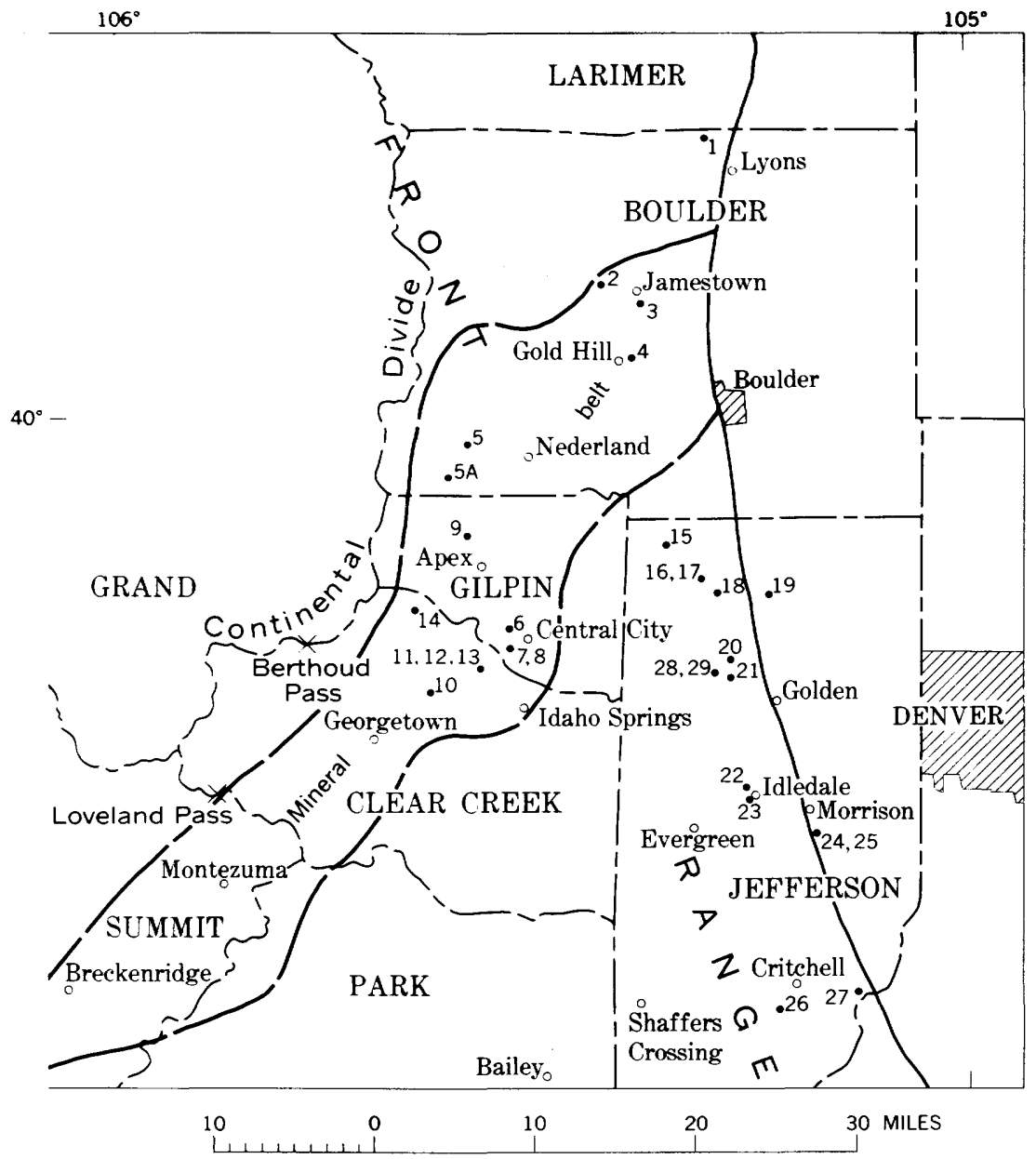

Figure 2.-Map of central part of Front Range, showing location of principal uranium deposits. Index to mines: Boulder County-1. Sisk; 2. Fair Day; 3. Blue Jay; 4. Black Cloud; 5. Caribou; 5A. Shirley. Gilpin County-6. Carroll; 7. Kirk; 8. Wood; 9. Unknown mine 2. Clear Creek County-10. Jo Reynolds; 11. Almaden; 12. Golconda; 13. Mary; 14. Gold Anchor. Jefferson County-15. Bankers Lode; 16. Mena; 17. North Star; 18. Schwartzwalder; 19. Old Leyden coal mine; 20. Aubrey Ladwig lease; 21. Union Pacific prospect; 22. Grapevine; 23. Foothills (Wright lease); 24. Four Corners; 25. Mann. No. 1; 26. Black Knight and Billikin lodes; 27. Seven Devils; 28. Ascension; 29. Ohman.

The uranium deposits outside the mineral belt are distributed along major fault systems related to the breccia reefs. They occur principally in the faults or fractures subsidiary to the major fault systems, generally in clusters. In the important Ralston Buttes district for example, the deposits are grouped in two main areas: the Ralston Creek area, along the Rogers fault system, and the Golden Gate Canyon area, along the Hurricane Hill fault system (fig. 20). In the 
same way, the deposits in the Idledale district (fig. 23) are clustered in an area of about a square mile between two major faults.

An isolated but significant deposit at the Copper King mine, in Larimer County, is not known to be related to the breccia reef fault system. At this mine, a vein that contains pitchblende and coffinite of Precambrian age cuts sulfide-bearing amphibole skarn (Sims and others, 1958).

\section{MINERALOGY}

The uranium minerals that have been identified from veins in the region are listed in table 2 . The primary minerals contain quadrivalent uranium and were deposited in a reducing environment. They are dominantly pitchblende (uraninite and amorphous $\mathrm{UO}_{3}$ ) and coffinite but include uranothorite and uraniferous hydrocarbon. The secondary uranium minerals, characterized by sexivalent uranium, were deposited in an oxidizing environment. They consist dominantly of phosphates but include silicates and less commonly the more soluble sulfates and carbonates. For a description of the various uranium minerals the reader is referred to the report by Frondel (1958). The ore and gangue minerals associated with the uranium minerals in the veins are discussed briefly in the section on classification and are listed in the tables describing the separate localities.

The term pitchblende is applied in this report to the colloform variety of uraninite and to the soft sooty amorphous $\mathrm{UO}_{3}$ that commonly is associated with the colloform material. This is the usage in Dana's "System of Mineralogy" (Palache and others, 1944) and of Frondel (1958, p. 35-36). An uncommon variety of pitchblende, hydropitchblende, has been recognized from the North Star mine in the Ralston Buttes district (Walker and Adams, 1963). Coffinite, a uranous silicate that contains a variable amount of hydroxyl (Stieff and others, 1956), closely resembles pitchblende and was not distinguished from it in the field. The mineral was identified by X-ray powder patterns and, with difficulty, in some thin and polished sections (Sims and others, 1961).

Pitchblende is the most abundant primary uranium mineral in the Front Range deposits and is the only one that has been identified in the deposits of the Central City district. Coffinite occurs with uraninite at the Copper King mine, in Larimer County (Sims and others, 1958, p. 206-209), the Fair Day and Blue Jay mines in Boulder County, the Schwartzwalder and Foothills mines and Old Leyden coal mine in Jefferson County, and at the Stanley mine in Clear Creek County (Sims and others, 1961). Uranothorite, a green metamict mineral that contains both uranium and thorium, has been identified at the Blue Jay mine in the Jamestown district (Phair and Shimamoto, 
TABLE 2.-Uranium minerals identified from vein deposits in the Front Range

\begin{tabular}{|c|c|c|c|c|c|c|}
\hline Uranium minerals & Composition 1 & 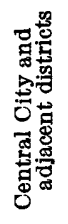 & 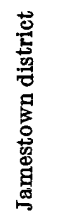 & 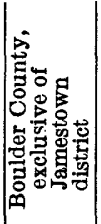 & 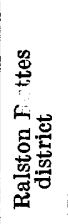 & 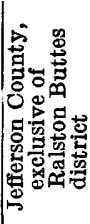 \\
\hline $\begin{array}{l}\text { Oxides: } \\
\text { Uraninite (pitchblende) } \\
\text { Becquerelite.................. }\end{array}$ & $\underset{2 \mathrm{UO}_{3} \cdot 3 \mathrm{H}_{2} \mathrm{O}}{\mathrm{UO}_{2}+}$ & $x$ & $x$ & $x$ & $x$ & $\stackrel{x}{x}$ \\
\hline $\begin{array}{l}\text { Phosphates: } \\
\text { Autunite and meta- } \\
\text { autunite } \\
\text { Bassetite.......... }\end{array}$ & $\mathrm{Ca}\left(\mathrm{UO}_{2}\right)_{2}\left(\mathrm{PO}_{4}\right)_{2} \cdot 8-12 \mathrm{H}_{2} \mathrm{O}$ & $x$ & $\stackrel{x}{x}$ & $x$ & $\times$ & $x$ \\
\hline nylite & 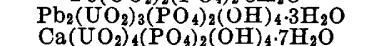 & $x$ & & $\mid-\cdots$ & $x$ & \\
\hline $\begin{array}{l}\text { Torbernite and metator- } \\
\text { bernite....-...-. } \\
\text { Silicates: }\end{array}$ & $\mathrm{Cu}\left(\mathrm{UO}_{2}\right)_{2}\left(\mathrm{PO}_{4}\right)_{2} \cdot 8-12 \mathrm{H}_{2} \mathrm{O}$ & $x$ & $x$ & $x$ & $\times$ & $x$ \\
\hline $\begin{array}{l}\text { Silicates: } \\
\text { Coffinite } \\
\text { Kasolite... }\end{array}$ & $\begin{array}{r}\left.\mathrm{U}\left(\mathrm{SiO}_{4}\right)_{1-\mathrm{x}} \mathrm{( \textrm {OH }}\right)_{4 \mathrm{x}} \\
\mathrm{Pb}\left(\mathrm{UO}_{2}\left(\mathrm{SiO}_{3}\right)(\mathrm{OH})_{2}\right.\end{array}$ & $x$ & $x$ & $\cdots$ & $x$ & $x$ \\
\hline pane............ & $\mathrm{Ca}\left(\mathrm{H}_{3} \mathrm{O}\right)_{2}\left(\mathrm{UO}_{2}\right)_{2}\left(\mathrm{SiO}_{4}\right)_{2} \cdot 3 \mathrm{H}_{2} \mathrm{O}$ & $\hat{x}$ & $x$ & $\cdots$ & $x$ & $\cdots$ \\
\hline $\begin{array}{l}\text { Sulfates: } \\
\text { Johannite- } \\
\text { Uranopilite- }\end{array}$ & $\underset{\left.\left(\mathrm{UO}_{2}\right)_{6}\right)_{2}\left(\mathrm{SO}_{4}\right)_{2}(\mathrm{OH})_{10} \cdot 12 \mathrm{OH}_{2} \mathrm{O}}{\mathrm{Cu}}$ & $x$ & & & $\stackrel{x}{x}$ & . \\
\hline$\theta$ and betazip- & B & & & & & \\
\hline $\begin{array}{l}\text { Carbon } \\
\text { Bayle }\end{array}$ & $\mathrm{Mg}_{2}\left(\mathrm{UO}_{2}\right)\left(\mathrm{CO}_{3}\right)_{3} \cdot 18 \mathrm{H}_{2} \mathrm{O}$ & $\begin{array}{l}x \\
x\end{array}$ & & & $\lambda$ & \\
\hline $\begin{array}{l}\text { zingerite } \\
\text { bearing hydro- }\end{array}$ & $\mathrm{NaCa}_{3}\left(\mathrm{UO}_{2}\right)$ & $\begin{array}{l}x \\
x\end{array}$ & & $x$ & $x$ & $\stackrel{x}{x}$ \\
\hline $\begin{array}{l}\text { Vanadates: } \\
\quad \text { Metatyuyamunite }\end{array}$ & $\mathrm{Ca}\left(\mathrm{UO}_{2}\right)_{2} \mathrm{~V}_{2} \mathrm{O}_{8} \cdot 3-5 \mathrm{H}_{2} \mathrm{O}$ & & & & & $x$ \\
\hline
\end{tabular}

1 After Weeks, Coleman, and Thompson (1959, p. 67); formulas for kasolite and dumontite are after Frondel (1958).

Composition is variable (see Frondel, 1958, p. 267).

1952). An unnamed uraniferous hydrocarbon found in a few localities is reddish brown to black, translucent, and has a pitchy luster and a low specific gravity.

The minerals characterized by sexivalent uranium are found in the oxidized parts of veins and clearly result from the oxidation and hydration of the primary quadrivalent uranium minerals. Autunite and meta-autunite, torbernite and metatorbernite, uranophane, kasolite, and, rarely, bassetite, dumontite, and phosphuranylite, are found at fairly shallow depths or locally at the surface. The more soluble sulfates and carbonates characteristically form efflorescences on mine walls.

\section{MINOR ELEMENTS IN PITCHBLENDE}

Analyses of pitchblende concentrates from various parts of the region indicate that several minor elements characteristically accompany the pitchblende. In this study we have attempted to identify the elements that were precipitated along with uranium and were trapped within the pitchblende structure. All analyses were made on material that was identified by X-ray methods as uraninite, although one sample contained some admixed coffinite. The analyses 
were made by the semiquantitative spectrographic method described by Myers, Havens, and Dunton (1961).

Many of the analyzed pitchblende concentrates contained minute inclusions of ore and gangue minerals which could not be completely eliminated by hand picking, and thus the mode of occurrence of each of the reported elements must be distinguished. Such inclusions are characteristic of pitchblende because of its colloform texture and relatively open mineral structure. The foreign minerals occur both in shrinkage cracks that developed during crystallization and in fractures of tectonic origin. In ores from Central City, quartz and several sulfide minerals occur in syneresis cracks in pitchblende and cement brecciated fragments of the mineral (Sims and others, 1963), and similar intimate intergrowths of sulfides and gangue with pitchblende have been noted in ores of the Ralston Buttes district (Walker and Adams, 1963, figs. 1 and 2). Trace-element content of the pitchblende concentrates is shown in table 3. Probably all the aluminum, iron, titanium, manganese, silver, cobalt, barium, beryllium, bismuth, chromium, copper, antimony, and zinc reported in the analyses can be regarded as inclusions of metallic minerals and gangues. Some lead is certainly a product of the radioactive disintegration of uranium, but some is doubtless in galena.

The elements zirconium, tungsten, yttrium, ytterbium, niobium, and probably also thallium are interpreted to be in the pitchblende structure, for these elements do not occur in appreciable amounts in the associated ore and gangue minerals and cannot be accounted for by inclusions. Zirconium is ubiquitous in the pitchblende and is locally abundant. It constitutes as much as 7 percent by weight of a pitchblende concentrate from the Little Annie mine in the Central City district. This high figure has been corroborated by quantitative spectrochemical analyses by $P$. R. Barnett (written communication, 1961), who found the zirconium content of three additional samples from the Wood-East Calhoun mines to be 5.4, 4.8, and 5.0 percent. These findings corroborate chemical analyses made long ago by Hillebrand (1891, p. 65-66), who found 7.59 percent $\mathrm{ZrO}_{2}$ in pitchblende that probably came from the Wood or Kirk mine on Quartz Hill. Such amounts of zirconium are high but are well within the experimental limits of solid solution of $\mathrm{ZrO}_{2}$ in $\mathrm{UO}_{2}$ (Frondel, 1958, p. 20). Neither petrographic nor $X$-ray studies have disclosed zircon as a separate phase with the pitchblende.

Tungsten occurs in small amounts in pitchblende concentrates from all areas except the Ralston Buttes and the Lawson districts. Yttrium is ubiquitous, and ytterbium and thallium are spotty in occurrence. Niobium is present in most pitchblende from the Ralston Buttes district. 


\section{TABLE 3.-Semiquantitative spectrographic analyses of pitchblende concentrates from veins in the central Front Range}

[Equivalent uranium analyses by C. G. Angelo and E. J. Young; semiquantitative spectrographic analyse ${ }^{\mathrm{s}}$ by N. M. Conklin, J. C. Hamilton, and R. G. Havens; figures for spectrographic analyses are reported to the nearest number in the series 7.0, 3.0,1.5, and so on, in percent; nd =not determined; $0=$ looked for but not detected; $<=$ less than number shown; $>=$ greater than number shown; elements looked for but not detected: P, Na, K, As, Au, B, Cd, Ce, Dy, Er, Ga, Gd, Ge, Hg, In, Ir, La, Li, Nd, Os, Pd, Pt, $\mathrm{Re}, \mathrm{Rh}, \mathrm{Ru}, \mathrm{Sn}, \mathrm{Sm}, \mathrm{Ta}, \mathrm{Th}, \mathrm{Te}]$

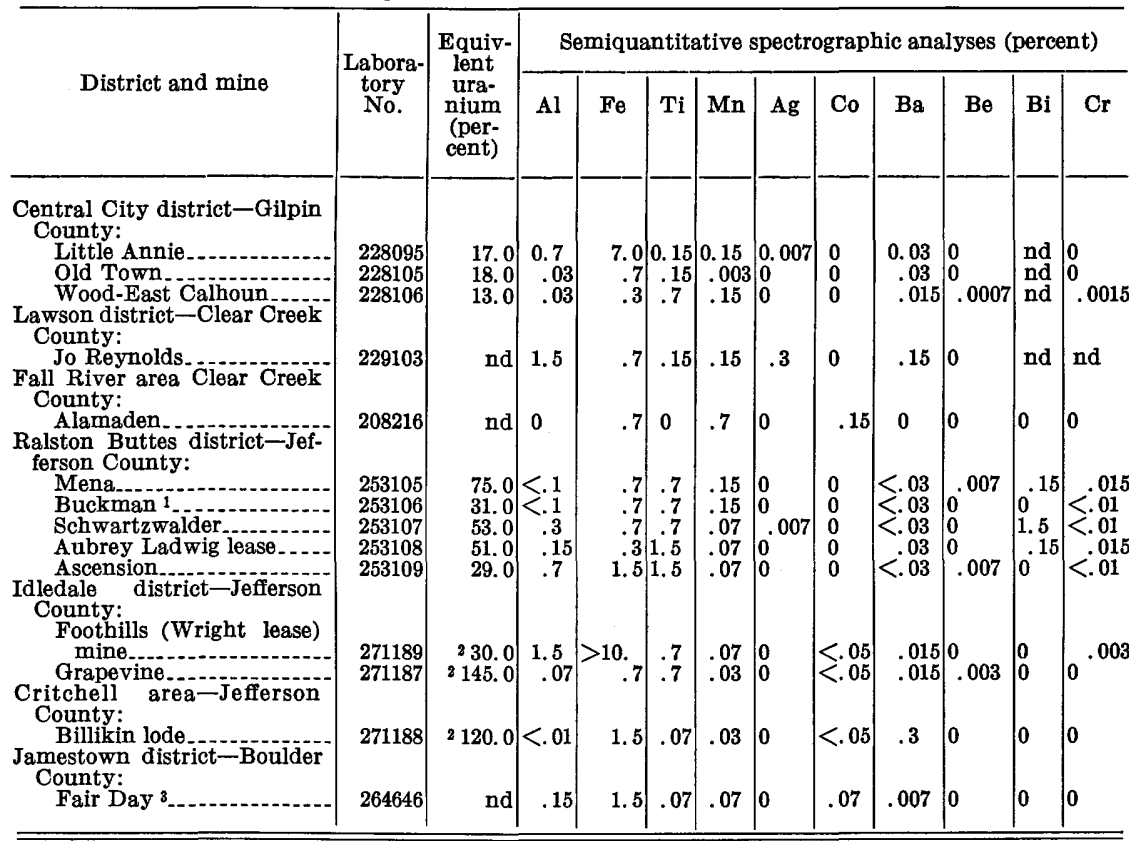

\begin{tabular}{|c|c|c|c|c|c|c|c|c|c|c|c|c|c|c|}
\hline \multirow{2}{*}{ District and mine } & \multicolumn{14}{|c|}{ Semiquantitative spectrographic analyses (percent) } \\
\hline & $\mathrm{Cu}$ & Mo & $\mathrm{Ni}$ & $\mathrm{Nb}$ & $\mathrm{Pb}$ & $\mathrm{Sb}$ & $\mathbf{v}$ & $\mathbf{w}$ & $\mathbf{Y}$ & $\mathbf{Y b}$ & Tl & $\mathbf{Z n}$ & $\mathbf{Z r}$ & $\mathrm{U}$ \\
\hline \multicolumn{15}{|l|}{ Central City district-Gilpin } \\
\hline $\begin{array}{l}\text { Lunty: } \\
\text { Little Annie. } \\
\text { Old Town } \\
\text { Wood-East Calhoun }\end{array}$ & $\begin{array}{c}0.3 \\
.07 \\
\text { nd }\end{array}$ & 0 & $\begin{array}{l}0 \\
0 \\
0\end{array}$ & $\begin{array}{l}0 \\
0 \\
0\end{array}$ & $\begin{array}{l}0.7 \\
.15 \\
.15\end{array}$ & \multirow[t]{2}{*}{$\begin{array}{l}0 \\
0 \\
0\end{array}$} & $\mid \begin{array}{l}0 \\
0 \\
0\end{array}$ & $\begin{array}{l}0 \\
.7 \\
.3\end{array}$ & $\begin{array}{r}0.15 \\
.15 \\
.15\end{array}$ & $\mid \begin{array}{l}0 \\
0 \\
0\end{array}$ & $\begin{array}{l}0 \\
0 \\
0\end{array}$ & $\begin{array}{l}1.5 \\
0\end{array}$ & $\left|\begin{array}{l}7.0 \\
3.0 \\
1.5\end{array}\right|$ & $\begin{array}{l}\gg 10.0 \\
>10.0\end{array}$ \\
\hline $\begin{array}{l}\text { Lawson district-Clear Creek } \\
\text { County: }\end{array}$ & & & & & & & & & & & & & & \\
\hline Fall River area-Clear Cree & .3 & .03 & 0 & 0 & 3.0 & 0 & 0 & 1.5 & .03 & 0 & 0 & 0 & 1.5 & $>10.0$ \\
\hline $\begin{array}{l}\text { County: } \\
\text { Almaden }\end{array}$ & .015 & .07 & .7 & 0 & 0 & 0 & 0 & 0 & .03 & 0 & 0 & & 0 & $>10.0$ \\
\hline $\begin{array}{l}\text { Ralston Buttes district-Jeffer- } \\
\text { son County: }\end{array}$ & & & & & & & & & & & & & & \\
\hline & .015 & 0 & 0 & .07 & .7 & $\mathbf{0}$ & 0 & 0 & .3 & nd & 0 & 0 & .7 & $>1$ \\
\hline Buckm & .015 & & 0 & .07 & .7 & 0 & .07 & 0 & .7 & .15 & 0 & 0 & .7 & \\
\hline (n-1 & .7 & $\begin{array}{l}.3 \\
.03\end{array}$ & $\mid \begin{array}{l}0 \\
0\end{array}$ & ${ }^{0} .7$ & $\begin{array}{l}1.5 \\
3.0\end{array}$ & $\begin{array}{l}\mathbf{0} \\
\mathbf{0}\end{array}$ & $\mid \begin{array}{l}0 \\
0\end{array}$ & $\mid \begin{array}{l}0 \\
0\end{array}$ & .15 & $\begin{array}{l}\text { nd } \\
\text { nd }\end{array}$ & $\begin{array}{l}0 \\
0\end{array}$ & $\begin{array}{l}0 \\
0\end{array}$ & $\begin{array}{l}.7 \\
1.5\end{array}$ & \\
\hline Ascension & .07 & 0 & 0 & .07 & 1.5 & 0 & 0 & 0 & .15 & nd & 0 & 0 & 1.5 & $>10$ \\
\hline ict-Jefferson & & & & & & & & & & & & & & \\
\hline ne. & .15 & 1.5 & 0 & 0 & .7 & 0 & .03 & .07 & .0 & .007 & 0 & 0 & .15 & \\
\hline & .07 & .03 & 0 & 0 & .7 & 0 & & .3 & .015 & nd & 0 & 0 & .3 & $>10$ \\
\hline $\begin{array}{l}\text { itchell area-Jefferson County: } \\
\text { Billikin lode }\end{array}$ & & & & & & & & & & & & & & \\
\hline district-Boulder & .03 & .015 & 0 & 0 & 1.5 & 0 & 0 & .3 & .07 & na & 0 & 0 & 1.0 & $>10$. \\
\hline Fair & .007 & .3 & .15 & & .15 & 1.5 & .007 & .3 & .03 & nd & .3 & & & $>10.0$ \\
\hline
\end{tabular}

1 Sample taken from narrow vein in road cut near Buckman adit.

2 Equivalent uranium analyses by E. J. Young with a microalpha counter; values greater than 100 percent probably indicate excess radioactive daughter products.

3 Contains some admixed coffinite. 
Molybdenum is present in detectable amounts in most of the analyzed samples and probably enters the pitchblende structure. Pitchblende samples from the Fair Day and Foothills mines (table 3) contain from a few tenths to a few percent molybdenum. A sample from the Fair Day mine analyzed by quantitative spectrochemical methods (P. R. Barnett, written communication, 1961) contained 62 percent uranium and 3 percent molybdenum. As the associated minerals contain very little molybdenum, and no molybdenite was recognized, the molybdenum is probably in the pitchblende structure. At the Schwartzwalder and Mena mines, molybdenum apparently occurs both in pitchblende and in some other form, as some samples contained as much as 0.95 percent molybdenum and the U:Mo ratio was only about 2 to 1 . This suggests that at least part of the molybdenum is present as molybdenite or as a minor constituent of the gangue and sulfide minerals, although molybdenite was not recognized in polished sections of the ore. Minor amounts of molybdenite tentatively identified in wall rocks of the Schwartzwalder mine may be related to a much earlier-probably Precambrianmineralization manifested principally by disseminated pyrrhotite and pyrite in some of the gneisses.

The occurrence of nickel and vanadium in pitchblende is equivocal. Nickel and associated cobalt in pitchblende from the Fall River area, Clear Creek County, can be accounted for by inclusions of the nickel arsenides niccolite and pararammelsbergite(?). (See Sims and others, 1963, fig. 22.) On the other hand, ore from the Fair Day mine also contains nickel and cobalt but has not been observed to contain nickel minerals. Vanadium probably is in inclusions in pitchblende, for it is known to be ubiquitous in the associated ore and gangue minerals from many localities.

\section{MINOR ELEMENTS IN COFFINITE}

Coffinite from the Fair Day and Copper King mines contains essentially the same minor elements as the pitchblende (table 4). The coffinite from both mines contains minute inclusions of other minerals that could not be completely removed from the samples. Among the identified inclusions in coffinite from the Copper King mine are siderite, pyrite, and sphalerite; and from the Fair Day mine, quartz, pyrite, sphalerite, chalcopyrite, and a clay(?) mineral.

Probably the aluminum, barium, calcium, copper, iron, manganese, silica, strontium, vanadium, and zinc reported in the analyses (table 4) occur in inclusions of other minerals in the coffinite. The lead probably results in substantial part from disintegration of uranium in the coffinite. Molybdenum, nickel, yttrium, and zirconium very likely occur in the coffinite structure. 
TABLE 4.-Quantitative spectrochemical analyses of coffinite from Fair Day and Copper King mines, Front Range

[Analyses by P. R. Barnett; $\mathrm{Al}$ and $\mathrm{Ca}$ determined by semiquatitative spectrographic method on sample diluted 1:9]

\begin{tabular}{|c|c|c|c|c|c|c|c|c|}
\hline Mine & $\begin{array}{l}\text { Labora- } \\
\text { tory No. }\end{array}$ & $\mathrm{U}$ & Al & $\mathrm{Ba}$ & $\mathrm{Ca}$ & $\mathrm{Cu}$ & $\mathrm{Fe}$ & Mn \\
\hline $\begin{array}{l}\text { Fair Day } 1 \\
\text { Copper King } 2 \\
\text { Copper King } 3\end{array}$ & $\begin{array}{l}289613 \\
289615 \\
289616\end{array}$ & $\begin{array}{l}54.0 \\
50.0 \\
45.0\end{array}$ & $\begin{array}{r}0.3 \\
.7 \\
.7\end{array}$ & $\begin{array}{r}0.042 \\
.031 \\
.024\end{array}$ & $\begin{array}{r}0.7 \\
.7 \\
.7\end{array}$ & $\begin{array}{l}0.04 \\
.015 \\
.03\end{array}$ & $\begin{array}{r}2.0 \\
6.0 \\
10.0\end{array}$ & $\begin{array}{r}0.15 \\
.13 \\
.42\end{array}$ \\
\hline
\end{tabular}

\begin{tabular}{|c|c|c|c|c|c|c|c|c|c|}
\hline Mine & Mo & $\mathrm{Ni}$ & $\mathrm{Pb}$ & $\mathbf{S i}$ & $\mathbf{S r}$ & $\mathbf{V}$ & $\mathbf{Y}$ & $\mathrm{Zn}$ & $\mathbf{Z r}$ \\
\hline $\begin{array}{l}\text { Fair Day }{ }^{1} \\
\text { Copper King } 2 \\
\text { Copper King }{ }^{3}\end{array}$ & $\begin{array}{r}5.0 \\
.6 \\
.5\end{array}$ & $\begin{array}{l}0.16 \\
<.002 \\
<.002\end{array}$ & $\begin{array}{l}0.8 \\
.45 \\
.35\end{array}$ & $\begin{array}{l}1.0 \\
1.0 \\
.95\end{array}$ & $\mid \begin{array}{l}<0.002 \\
<.002 \\
<.002\end{array}$ & $<\begin{array}{l}0.015 \\
<.01 \\
.01\end{array}$ & $\begin{array}{r}0.19 \\
.13 \\
.08\end{array}$ & $\begin{array}{l}<0.5 \\
<.5 \\
<.5\end{array}$ & $\begin{array}{r}0.025 \\
.27 \\
.23\end{array}$ \\
\hline
\end{tabular}

1 Mineral is black and pitted and has a dull luster.

2 Mineral is black and smooth and has a variable luster.

3 Coffinite has a frosty appearance due to abundant admixed siderite.

\section{CLASSIFICATION OF DEPOSITS}

The uranium deposits in the Front Range can be grouped according to mineral assemblage into three classes, which are distinctive but to a certain extent overlapping. These are (1) uranium-bearing fluorite veins and breccias, (2) uranium-bearing base-metal sulfide veins, and (3) veins in which uranium minerals are dominant. This classification is adapted from one proposed by Walker and Osterwald (1963); it is useful not only to distinguish mineralogic character but also serves to distinguish deposits roughly according to grade and size.

CLASS 1 DFPOSITS-URANIUM-BEARING FLUORITE VEINS AND BRECCIAS

Uranium-bearing fluorite veins and breccias are characterized by abundant fluorite and minor amounts of uraninite, coffinite, uranothorite, and secondary uranium minerals. Quartz, clay minerals, rhombohedral carbonate minerals, iron oxides, and sparse pyrite, galena, tetrahedrite-tennantite, sphalerite, and chalcopyrite occur with the fluorite. The fluorite veins and breccias are characteristic of the Jamestown district and are not known in the Front Range outside of that district. The fluorite veins have been described in some detail by Goddard (1946, p. 13-20), Lovering and Goddard (1950, p. 260263), and Phair and Shimamoto (1952).

The uraninite, and probably also the coffinite, in the veins and breccias of the Jamestown district is intergrown with a deep-purple semiopaque fluorite and to a lesser extent with sulfide ore minerals, but not all deep-purple fluorite contains uranium. It is characteristically more abundant in the matrix of the breccias than in the large fluorite fragments and is generally absent from pale-purple or white fluorite (George Phair and Kiyoko Onoda, written communication, 1950). 
The uranothorite most commonly occurs as inclusions in deep-purple fluorite, but it also is intergrown with sphalerite and other minerals in the matrix of the fluorite breccias (Phair and Shimamoto, 1952, p. 661-663).

The radioactivity and uranium content of uranium-bearing fluorite veins and breccias is variable but low, as can be ssen on table 6, and none of the deposits have been mined for uranium. Only a few selected samples of fluorite-bearing ore or fluorite concentrates contain more than 0.01 percent equivalent uranium. As might be expected from the presence of uranothorite-a thorium-bearing mineral the radioactivity (equivalent uranium) exceeds the uranium content in all samples.

\section{CLASS 2 DEPOSITS-URANIUM-BEARING BASE-METAI SULFIDE VEINS}

Uranium-bearing base-metal sulfide veins are characterized by abundant base-metal sulfides and sparse pitchblende in a quartz or carbonate gangue. Coffinite is rare, so far as known. Gold and silver are commonly valuable constituents of the veins and may be the most important ones. Deposits of this type are characteristic of the metal-mining districts of the Front Range mineral belt and are particularly well represented at Central City (Sims and others, 1963; Drake, 1957), another well-known example is at Caribou in Boulder County (Moore and others, 1957; Wright, 1954).

In this type of deposit, pitchblende occurs as small lenses or pods erratically distributed along the veins. The pitchblende in the lenses may be relatively pure or may be intimately admixed with sulfide minerals. Commonly the veins are nearly barren of uranium between the uranium ore lenses. An excellent example of a uranium deposit of this class is the Carroll vein at Central City, which contains pitchblende in association with galena-sphalerite ore (Sims, 1956a, p. 751754). The pitchblende occurs as small high-grade stringers and pods that generally contain only a few hundred pounds of ore but in aggregate may constitute minable uranium ore bodies. The stringers and pods may lie along the walls of the vein or may be enclosed in the sulfide ore. Some stringers along the walls can be mined separately, but those in the galena-sphalerite ore generally can not. The proportion of uranium to other metals in the Carroll vein is roughly indicated by the output for the years 1954 and $1955 ; 63$ tons of crude ore and 107 tons of concentrates shipped during this period contained a total of 55 ounces of gold, 1,714 ounces of silver, 844 pounds of copper, 52,905 pounds of lead, 56,767 pounds of zinc, and 349 pounds of $\mathrm{U}_{3} \mathrm{O}_{8}$.

In another variety of class 2 deposit, pyrite greatly predominates over other sulfide minerals. Examples of such deposits are the Kirk, 
Wood, and German veins on Quartz Hill, in the Central City District. As in the galena-sphalerite veins, the pitchblende occurs as veinlets or pods along the walls of the veins. Many of the pods are extremely rich and contain ore assaying as much as 60 percent $\mathrm{U}_{3} \mathrm{O}_{8}$, but in others it is intimately admixed with pyrite or other minerals. Although pitchblende excites much interest, quantitatively it constitutes only a small proportion of the volume and dollar value of the ore from veins of this kind (Drake, 1957).

The veins of this class formed by filling of open spaces, but they contain only small and widely spaced vugs. Their structure and mineral assemblage are diagnostic of veins classified by Lindgren (1933, p. 529-532) as mesothermal.

\section{CLASS 3 DFPOSTTS-VFINS IN WHICH URANIUM MINERALS ARE DOMINANT}

In class 3 deposits, uranium is the only constituent abundant enough to warrant mining and in many deposits is in the form both of coffinite and of pitchblende. Sulfide minerals are generally sparse, and among them, pyrite predominates. In some veins, even gangue minerals are sparse. The ore minerals are noticeably finer grained than in class 2 deposits and occur in banded crustified or colloform aggregates. The veins typically have abundant open spaces and in general have the characteristics of epithermal deposits (Lindgren, 1933, p. 444452 ).

Class 3 deposits occur on the periphery of the mineral belt and comprise the valuable deposits in Jefferson County and in the Fair Day mine in the Jamestown district. They include the most important uranium deposits known in the Front Range, and some contain as much as a few thousand tons of ore. In typical deposits of this class, the primary uranium minerals and associated gangue minerals fill cracks and other voids and form crustiform coatings on the walls or on breccia fragments. The ore bodies have widths of a foot to as much as several feet and heights and breadths of several tens of feet. Many of the ore bodies have "assay walls," and grade of the ore as mined thus ranges widely. Base-metal content of the ore rarely exceeds 1 or 2 percent, and the precious-metal content is virtually nil.

\section{PARAGENESIS}

With few exceptions, the primary uranium minerals were deposited early in the vein-forming sequence, after precipitation of most of the gangue and before deposition of most of the associated metallic minerals. Pitchblende, the principal primary mineral, is accompanied in some deposits by coffinite which is generally paragenetically the younger. Both minerals display the colloform textures (Bastin, 1950, 


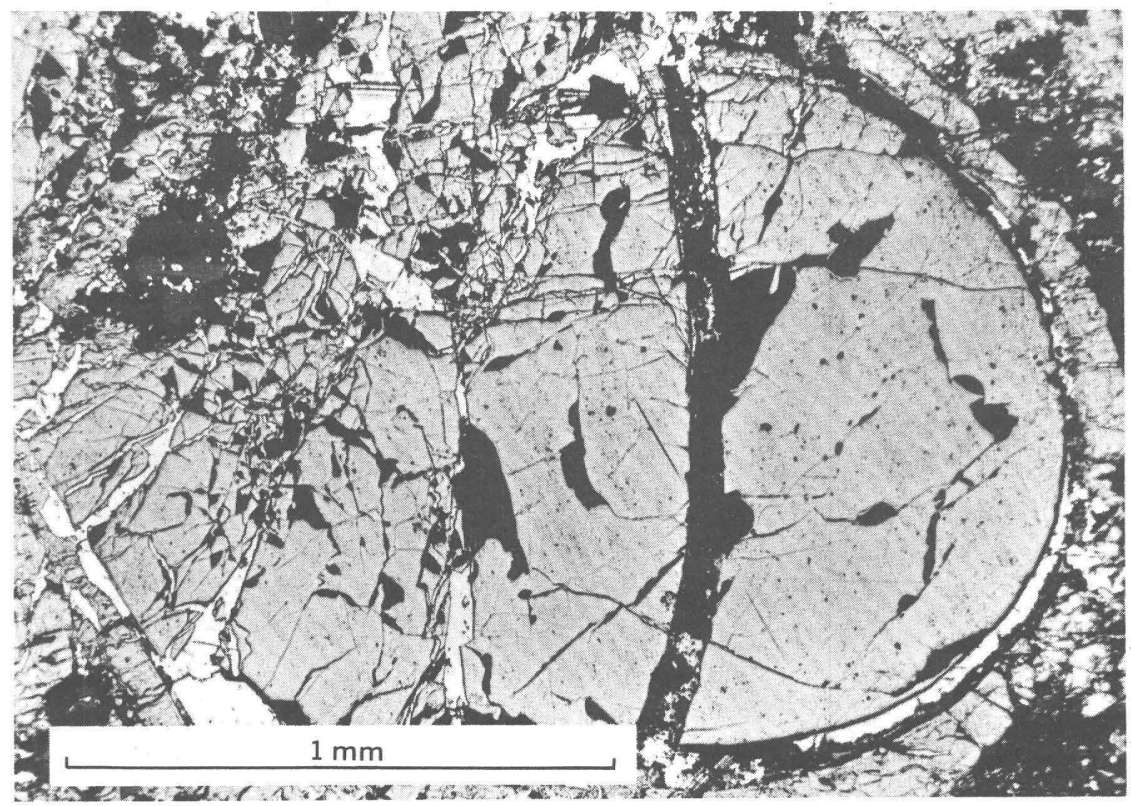

FIGURE 3.-Photomicrograph of a polished section of colloform pitchblende from the J. P. Whitney mine, Central City district. Galena (white) and quartz (black) fill a concentric shrinkage crack near the margin of the spheroidal grain; galena fills numerous irregular fractures of probable tectonic origin.

p. 25-32) found in black uranium ores in many parts of the world, as at the Eldorado mine at Great Bear Lake, Canada (Kidd and Haycock, 1935), in the Goldfields region, Canada (Robinson, 1955), in France (Geffroy and Sarcia, 1954), in central Europe (Ramdohr, 1955), and in Russia (Tishkin and others, 1958).

The pitchblende (and coffinite) grains are mainly of microscopic dimensions but botryoid bodies as much as an inch across have been found at the Kirk mine in the Central City district and at the Mena mine in the Ralston Buttes district. Typical textures of primary uranium minerals from the Front Range have been illustrated previously (Sims and others, 1963; Walker and Adams, 1963; Wright, 1954) but are described briefly in the following paragraphs in order to compare those from class 2 and class 3 deposits.

The most common textural forms of pitchblende in class 2 deposits are spheroidal grains and aggregates (fig. 3). Individual grains are commonly 1-2 $\mathrm{mm}$ in diameter, and some are nearly perfect spheres. The spheroidal grains generally have radial and concentric fractures, which are interpreted as syneresis or shrinkage cracks. These fractures may be filled with later sulfide and gangue minerals. A few spheroidal grains have a pronounced concentric layering of pitchblende and gangue (commonly quartz) or of pitchblendes of detect- 


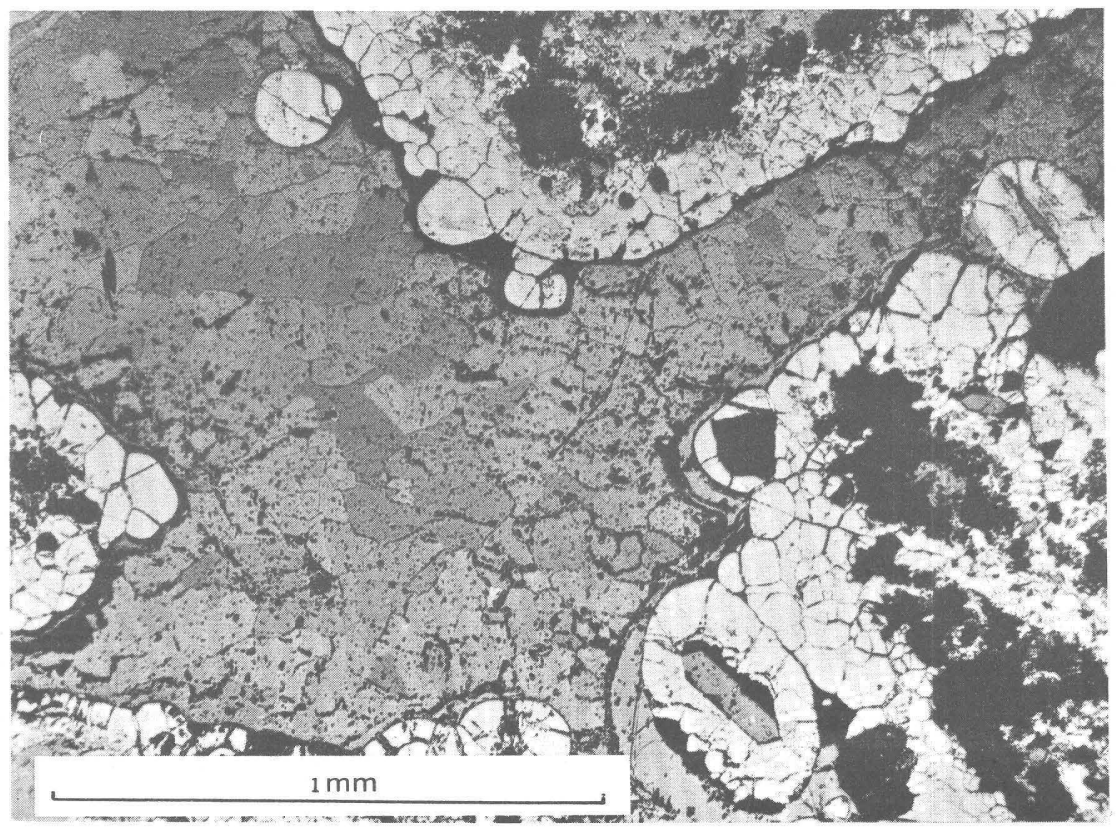

FIGURE 4.-Photomicrograph of a polished section of pitchblende ore from the Jo Reynolds mine, Lawson area, Clear Creek County. Pitchblende (white) occurs as veinlets and as small colloform grains around quartz cores (gray). Note the straight contacts (interference surfaces) between different parts of the pitchblende.

ably different compositions. Pitchblende veinlets of the class 2 deposits are shown by the reflecting microscope to be irregular colloform bands that have an outer (younger) botryoidal surface and an inner ragged margin (fig. 4). They crystallized in a manner similar to the spheroidal grains, by growing outward from a surface of deposition. Pitchblende at Central City and some other localities in the mineral belt commonly is crackled or brecciated, largely as a result of tectonic movements since deposition. The brecciated fragments are cemented by later pitchblende or by gangue and sulfide minerals, and some are veined by later minerals.

Pitchblende from class 3 deposits is somewhat finer grained than that of the class 2 deposits just described and is associated with dominantly crustiform ores, some of which have a delicate colloform banding. The character of pitchblende ore typical of class 3 deposits is shown in figure 5 as well as in the report of Adams and Stugard (1956c, pls. 12 and 13). Typically, the pitchblende coats crystals of ankerite or other gangue minerals and forms rims, veinlets, and segmented veinlets; less commonly it occurs as spheroidal grains or as aggregates of spheres in a gangue matrix. The aggregates constitute a typical framboidal texture (Bastin, 1950). The veinlets and rims 
are made up of grains, a few microns in diameter, packed like biscuits. Some pitchblende is veined and partly replaced by later sulfide minerals (Adams and Stugard, 1956c). Pitchblende from the Fair Day mine at Jamestown has the textural features described above but is intimately intergrown with coffinite and interbanded with colloform sulfides and quartz (fig. 6). In some of the ores from the Fair Day mine, pitchblende forms a fine emulsionlike intergrowth with pyrite, similar to that illustrated in figure 7. As can be seen in the photomicrograph, the pyrite above the convex (younger) sides of the veinform pitchblende contains closely spaced minute pellets of pitchblende in an emulsionlike texture. This mixture grades laterally into nearly homogeneous pyrite, yet it is sharply defined from the underlying

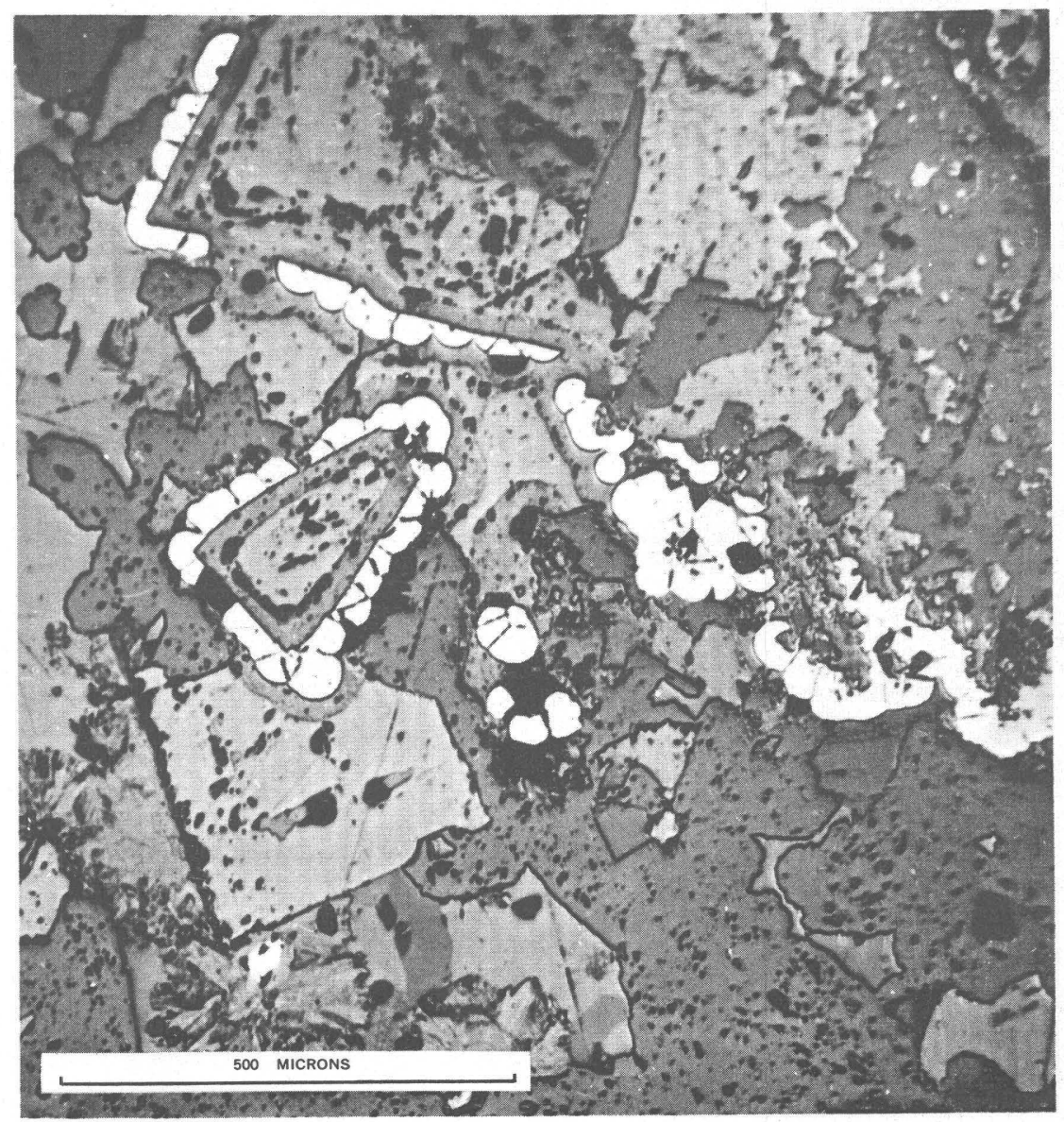

FIgURE 5.-Photomicrograph of a polished section of pitchblende ore from the Mena mine, Ralston Buttes district, Jefferson County. Pitchblende (white) coats crystals of ankerite and occurs as spheroidal grains and as aggregates of spheres in the gangue. 


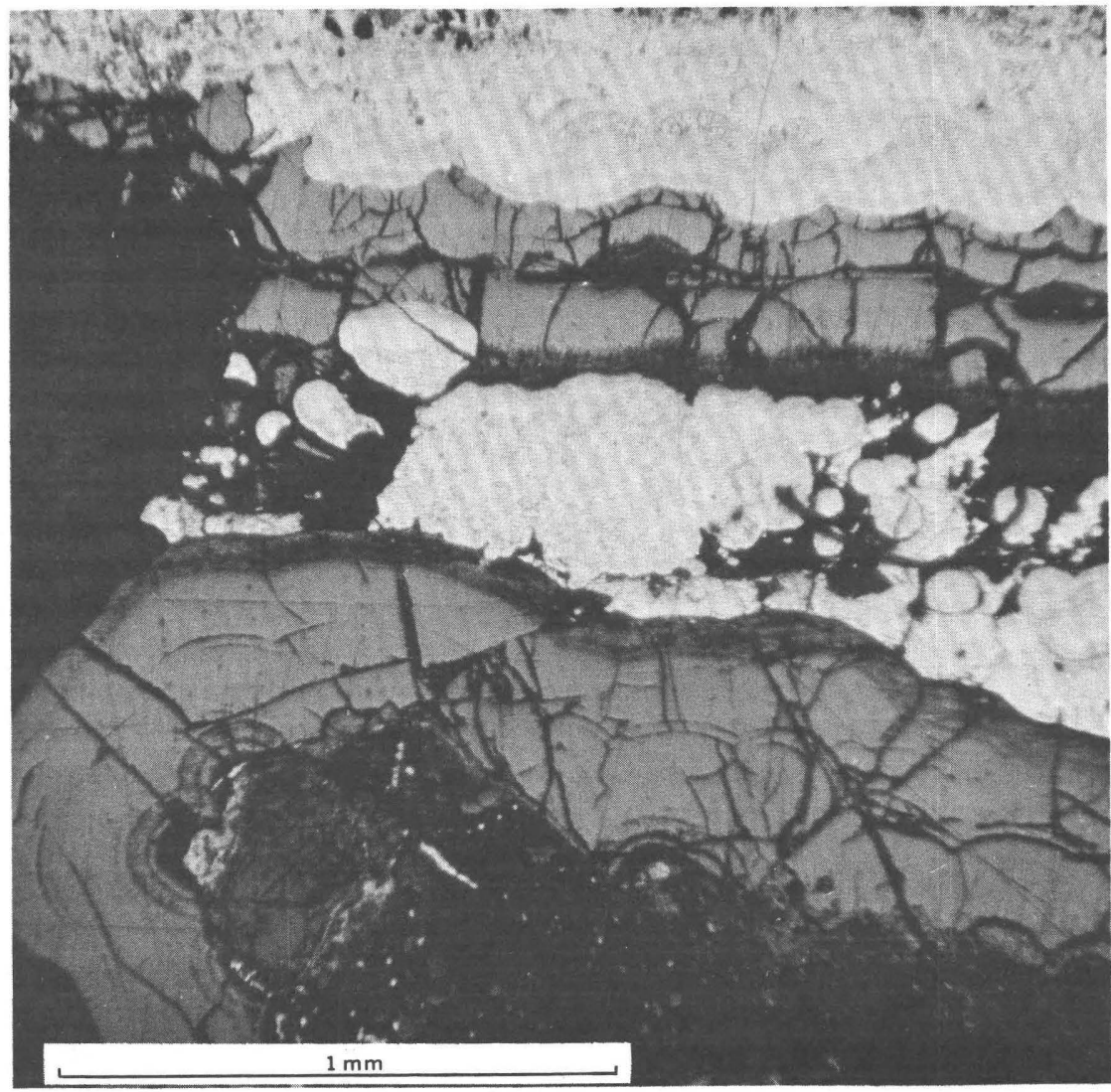

Figure 6.-Photomicrograph of a polished section from the Fair Day mine, Jamestown district, showing pitchblende (gray) intercalated with colloform pyrite (white). Marcasite with radiating fibers locally occurs as rims on pyrite.

homogeneous pitchblende. Shrinkage cracks occur both in the pitchblende and in the fine intergrowth of pitchblende and pyrite, but they die out abruptly in the more homogeneous pyrite.

Sootlike pitchblende, consisting of minute gray to black particles, occurs in minor quantity in deposits of all three classes. In some of the deposits, it coats hard unaltered pitchblende, and in others it is the only form of pitchblende present. Most of it is probably secondary and appears to have been deposited in a zone of transition between the zones of primary ore and of highly colored secondary uranium minerals. In this transitional zone, the environment was neither strongly reducing nor strongly oxidizing.

All the coffinite in class 3 deposits occurs with pitchblende and has much the same form as the pitchblende. In ores from the Fair Day mine, coffinite is intercalated with pitchblende and pyrite as colloform 
bands (fig. 8), or coats the pitchblende and embays it (fig. 9). Where embayment occurs, the coffinite penetrates the pitchblende irregularly, apparently without regard to fractures, and some shrinkage cracks in pitchblende extend outward into the coffinite. Thus the replacement of pitchblende by coffinite must have occurred before the originally gellike bodies crystallized. In detail, the contacts between pitchblende and coffinite are always sharp, even when observed under high magnification, but they are commonly bulbous or mamillary and have a scalloped appearance (fig. 10).

Coffinite from the Fair Day mine contains abundant minute inclusions of other minerals, a characteristic of coffinite described from other terranes (Frondel, 1958). Among the inclusions found in the coffinite-but not in associated pitchblende-are chalcopyrite, sphalerite, pyrite, and gangue minerals (fig. 11) in particles ranging in diameter from a few microns to about $2 \mathrm{~mm}$. The pyrite inclusions occur as small colloform grains, commonly in typical framboidal arrangement, and as small subhedral to euhedral crystals. Chalcopyrite occurs as colloform masses, generally with some visible crystal outlines against coffinite (fig. 11) and commonly near the center of the larger colloform masses of coffinite, although it may also be distributed irregularly through the coffinite. Sphalerite is associated with the

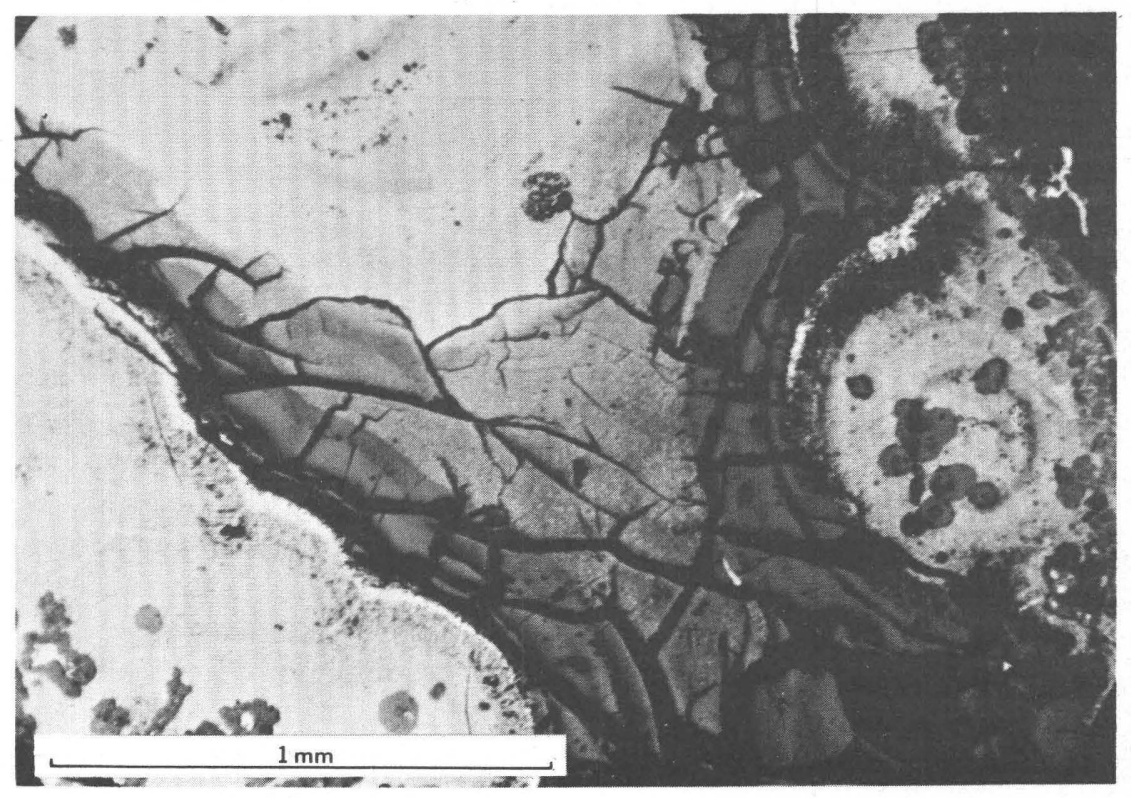

FIGURE 7.-Photomicrograph of a polished section of ore from the Fair Day mine, Jamestown district. Colloform bands of pitchblende (dark gray) that were deposited on colloform pyrite (white) are succeeded by an emulsionlike intergrowth of pitchblende and pyrite (light gray). This material grades laterally into nearly homogeneous pyrite. The pellets and framboidal aggregates in the pyrite are pitchblende. 


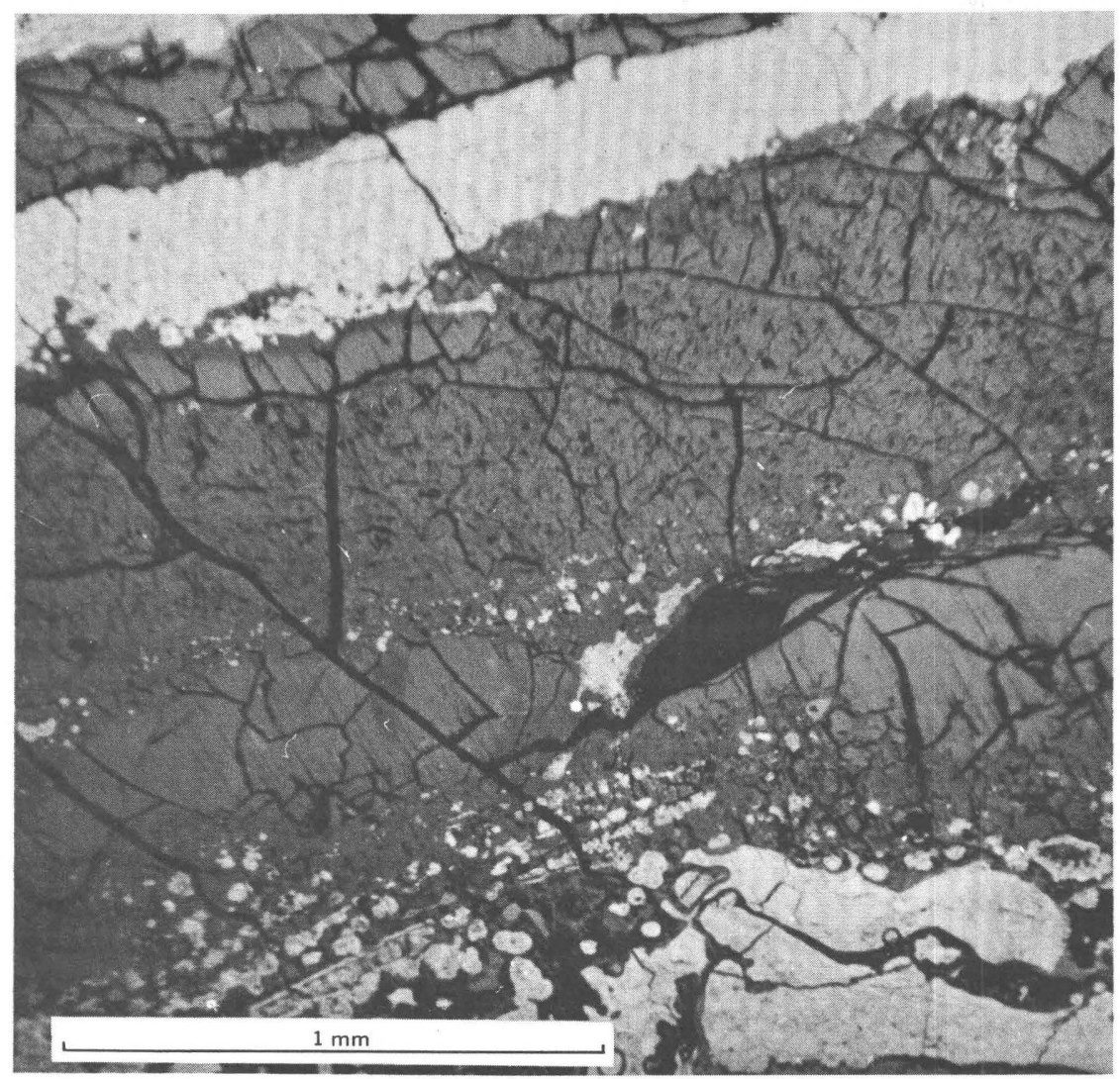

FIGURE 8.-Photomicrograph of a polished section of coffinite-pitchblende ore from the Fair Day mine, Jamestown district. Coffinite (dark gray) is intercalated with pitchblende (medium gray) and pyrite (white). The irregular cracks are interpreted as syneresis or shrinkage cracks.

chalcopyrite and also forms discrete grains and veinlets irregularly distributed in coffinite; it constitutes more than 5 percent of some samples of coffinite ore. Molybdenum salts coat the weathered surfaces of some coffinite ore, and in the laboratory, they form by reaction of coffinite with $\mathrm{FeCl}_{3}$. Although the source of the molybdenum has not been recognized, it may be in the form of minute inclusions of jordisite. The gangue-mineral inclusions have not been identified with certainty but appear to be dominantly finely divided sericite.

Since publication of the report on the Copper King mine (Sims and others, 1958), coffinite has been found to be the chief constituent of the black uranium ore formerly identified as pitchblende. The coffinite is intergrown with pitchblende (uraninite) and has a conspicuous colloform structure. It occurs as irregular veinlets or 


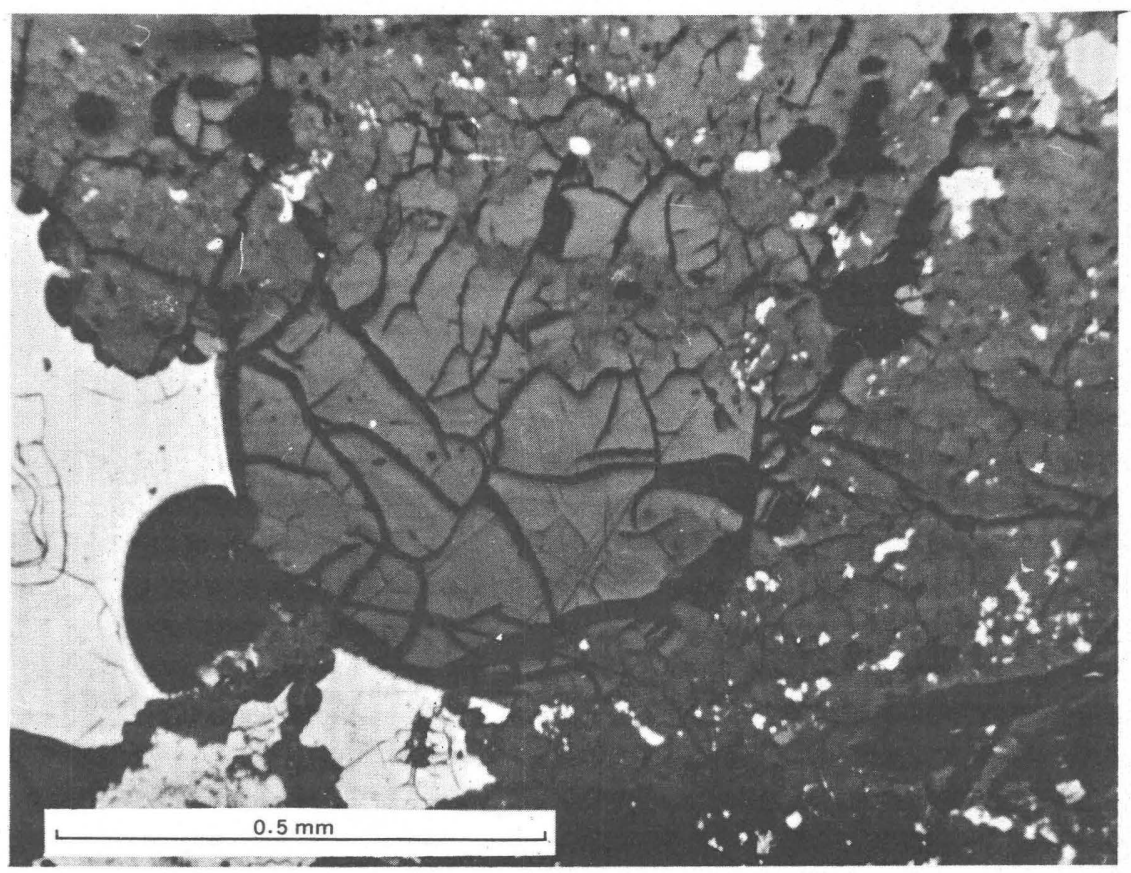

FIGURE 9.-Photomicrograph of a polished section of coffinite-pitchblende ore from the Fair Day mine, Jamestown district. Coffinite (dark gray) partly surrounds and embays and veins a spheroidal grain of pitchblende (medium gray). Both the coffinite and the pitchblende have conspicuous irregular shrinkage cracks, some of which extend from one mineral into the other. Note that the coffinite contains abundant minute inclusions of pyrite (white), gangue (black), and pitchblende.

spheroidal bodies in fissures filled dominantly with siderite. Individual grains tend to have ragged, irregular outlines that contrast markedly with the smooth rounded outlines characteristic of pitchblende. Uraninite occurs generally as tiny rotund grains dispersed through the coffinite. Contacts between the coffinite and uraninite are smooth and curved, indicating that the two minerals probably formed nearly contemporaneously. The coffinite is finely intergrown with siderite and contains minute inclusions of pyrite.

Studies of the sequence of deposition indicate that pitchblende generally was deposited early, or at least early in any particular stage of vein filling, and that coffinite generally formed somewhat later. An early position for pitchblende in the depositional sequence is in accord with broader conclusions of Walker and Adams (1963), who stated:

Paragenetic studies of deposits in the conterminous United States suggest a sequence of deposition in which pitchblende is an early ore mineral. Pitchblende may be preceded by some gangue or by iron sulfides or oxides (rarely, nickelcobalt sulfosalts), but its deposition commonly starts before that of most associated metallic minerals and the bulk of the gangue in any single stage of mineralization. 


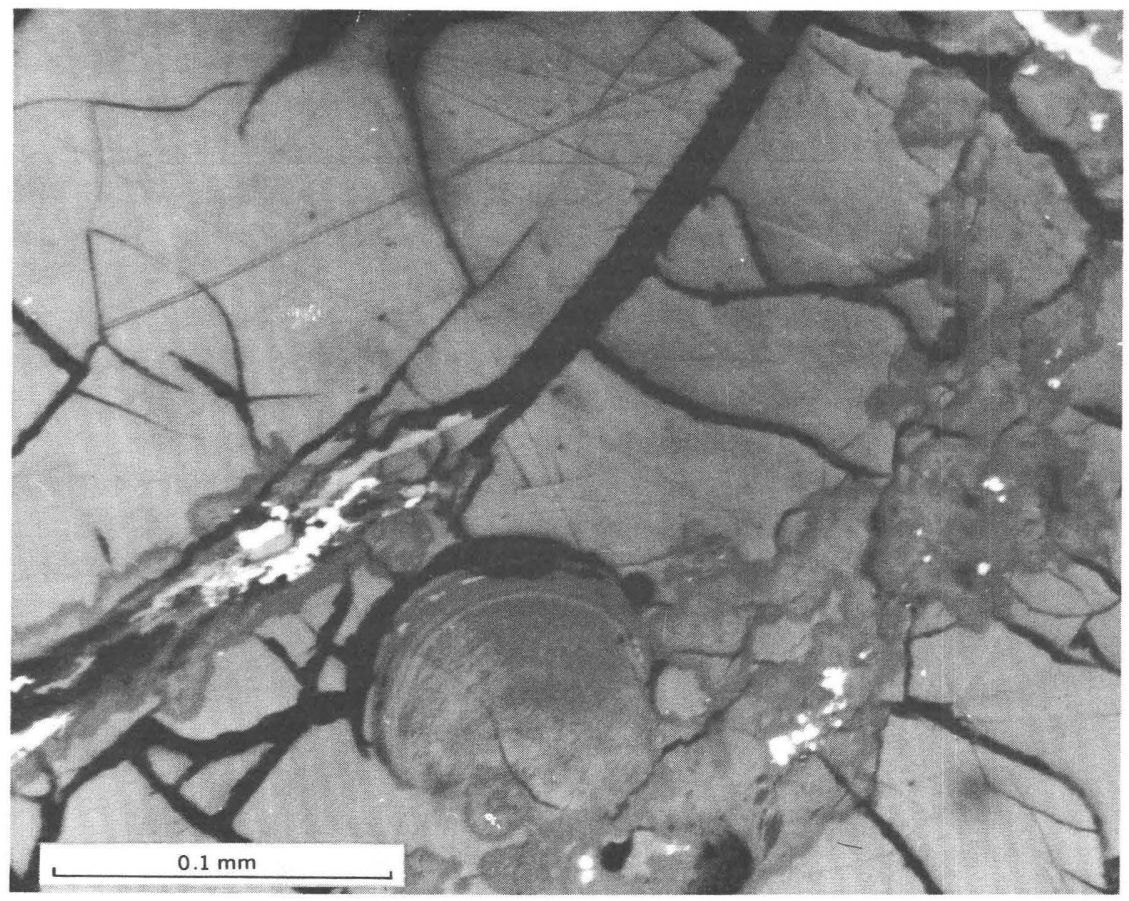

FIGURE 10.-Photomicrograph of a polished section of coffinite-pitchblende ore from the Fair Day mine, Jamestown district. A highly irregular veinlet of coffinite (darker gray), consisting of numerous rotund forms, transects and replaces pitchblende. One spheroidal form in the coffinite has a conspicuous con centric colloform banding.

In the class 2 deposits at Central City, pitchblende was deposited during the first of three distinct stages of ore deposition, apparently in part before the wallrocks were completely altered (Sims, 1956a; Sims and others, 1963). Quartz, which generally is white or gray and coarsely crystalline, and some pyrite in the form of cubes or pyritohedrons crystallized with pitchblende during the first stage of mineralization. Following a period of fracturing that reopened the vein fissures and locally brecciated the early minerals, additional pyrite and quartz formed (pyrite-stage mineralization), largely as a culmination of wallrock alteration. This stage was succeeded by a base-metal stage, which followed another period of fracturing and brecciation. The base metals were deposited according to a well-defined zonal arrangement, and thus pitchblende is associated with a somewhat different suite of sulfide minerals in various parts of the district.

At the Caribou mine in a class 2 deposit in Boulder County, Wright (1954, p. 156-162) determined that pitchblende formed early in the 


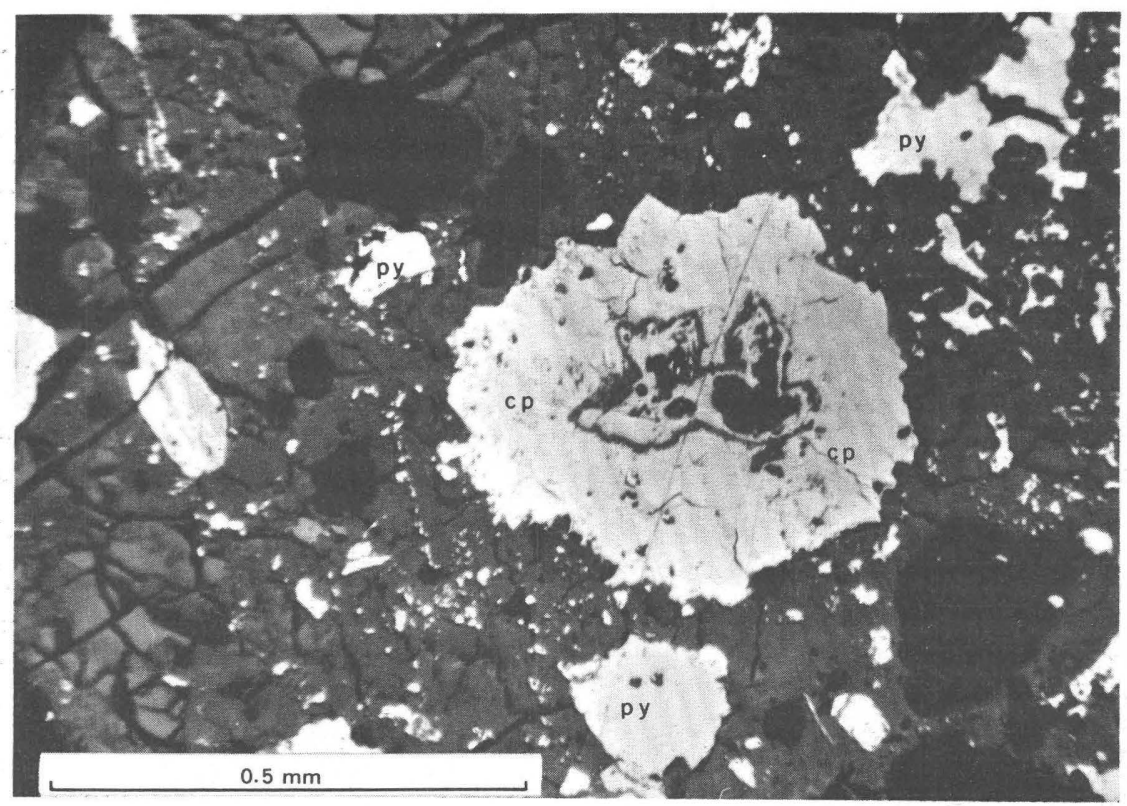

Figure 11.-Photomicrograph of a polished section of ore from the Fair Day mine, Jamestown district. Coffinite (dark gray) contains a spheroidal mass of chalcopyrite (cp), abundant irregularly distributed aggregates of colloform grains of pyrite (py), and small bodies of gangue (black). The chalcopyrite contains thin colloform bands of coffinite. The shrinkage cracks are confined mainly to the coffinite.

second of two recognized stages of mineralization, as summarized below:

Stage A

1. Quartz with calcite and siderite

2. Pyrite(?)

3. Chalcopyrite

4. Sphalerite

5. Galena

Stage B

1. Gersdorffite and chalcedony

2. Uraninite and chalcedony (with minor pyrite)

3. Sphalerite and chalcopyrite

4. Pyrite

5. Argentite with chalcopyrite

6. Proustite (followed by very minor uraninite)

7. Native silver.

He noted (1954, p. 162) that the chalcedony has a well-developed colloform texture and that the succeeding sphalerite and pyrite are conformably banded on botryoidal surfaces of uraninite. Replacement of uraninite by sphalerite, proustite, and argentite was noted; some uraninite deposited late in stage B is thought by Wright (1954, p. 161) to represent redeposition of earlier formed material. 


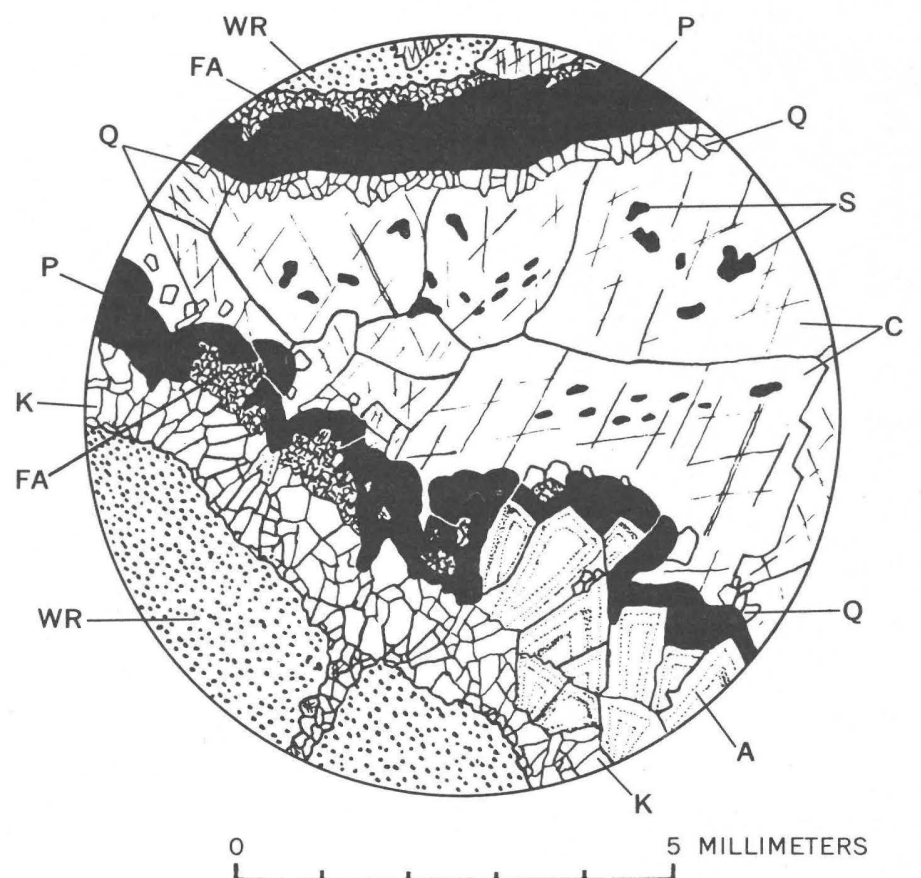

FIGURE 12.-Camera lucida drawing of thin section of pitchblende-bearing ore from the North adit of the Mena mine, Ralston Buttes district, Jefferson County. $\mathrm{S}$, base-metal sulfide minerals; C, carbonate mineral (ankerite or calcite); $\mathrm{Q}$, quartz; P, pitchblende; A, ankerite showing growth zoning; FA, fine-grained ankerite; K, potassic feldspar; WR, fragment of altered wallrock.

Paragenetic studies of class 3 deposits in the Ralston Buttes district indicate that pitchblende was deposited before most sulfides, and that generally a period of fracturing intervened between the pitchblende and sulfide stages. The paragenetic sequence at the Union Pacific prospect (fig. 13) shows that pitchblende was deposited nearly contemporaneously with ankerite and hematite and before several sulfide minerals. In the Mena vein, the order, as determined by Sheridan, was (a) potassic feldspar, (b) zoned ankerite, (c) pitchblende, followed by minor quartz, and (d) late ankerite or calcite and base-metal sulfide minerals. This sequence is illustrated in figure 12. The paragenetic sequence at the Schwartzwalder mine (F. W. Kuehnel, written communication, 1956) is similar to that at the Union Pacific prospect but is more complicated because of several periods of intramineral and postmineral fracturing.

In the class 3 deposit of the Fair Day mine, pitchblende and minor pyrite and quartz were the first minerals deposited. Coffinite was 


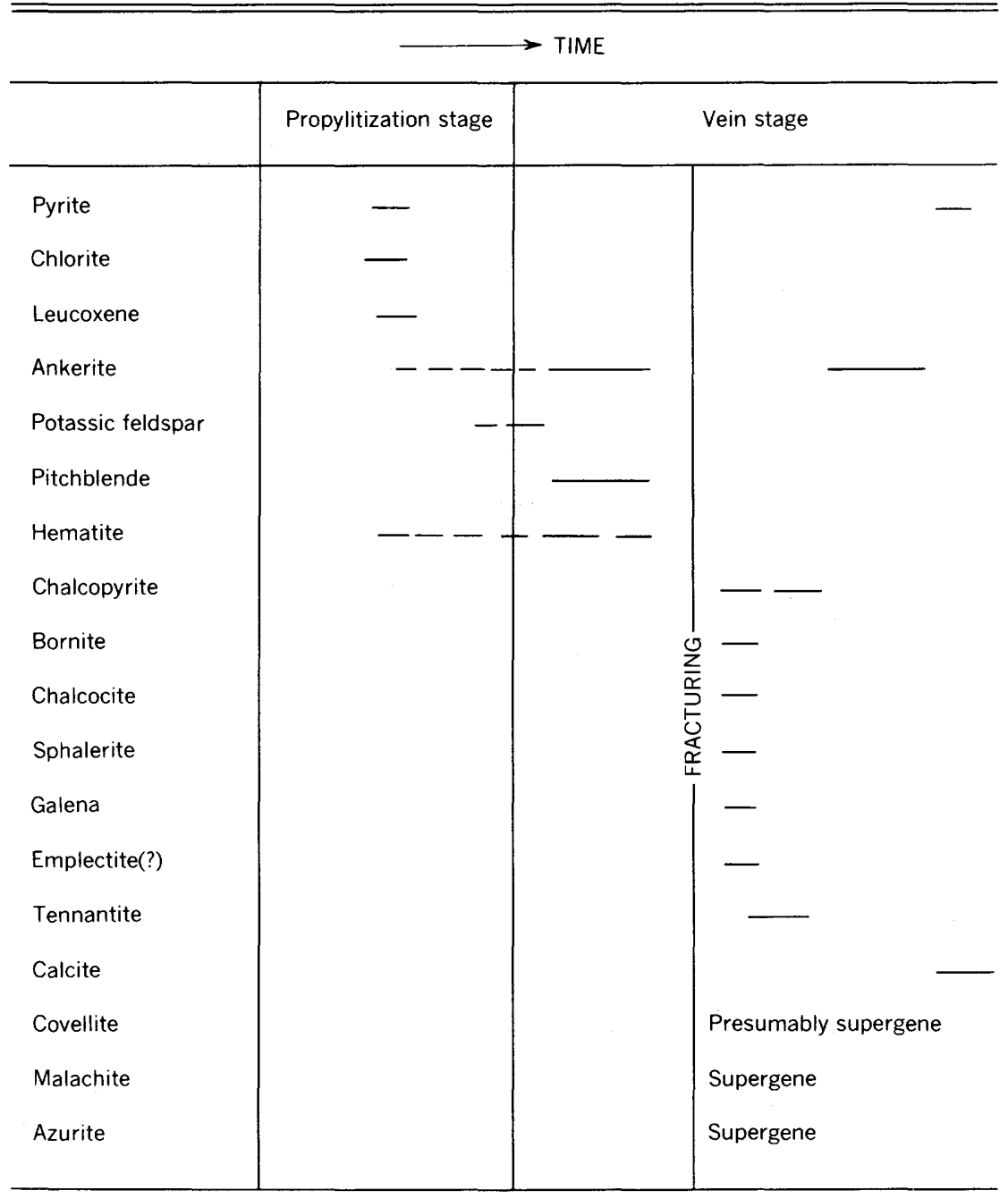

Fiqure 13.-Paragenetic sequence of minerals at the Union Pacific prospect, Jefferson County, Colo. (from Adams and Stugard, 1956c, p. 203).

deposited later, in company with additional quartz and various sulfide minerals, including colloform pyrite and marcasite. No uranium-free sulfide stage is recognized. The observation that the coffinite of this mine is paragenetically later than pitchblende (uraninite) is in accord with the findings of Weeks and Coleman on the Colorado Plateau (in Garrels and Christ, 1959, p. 84) and of Paul Ramdohr (oral communication, 1960) at Wolsendorf, Bavaria. 


\section{WALLROCKS AND THFIR ALTERATION}

The uranium deposits of the Front Range are found in many different kinds of Precambrian metamorphic and granitic host rocks and locally in porphyritic igneous rocks of Laramide age and sedimentary rocks of Cretaceous age. The metamorphic and igneous host rocks are altered adjacent to the veins, in places to successive argillic and sericitic mineral zones and in other places to apparently uniform chloritized or argillized rocks.

The veins within the crystalline core of the range occur in Precambrian rocks of all kinds but are mainly in metasedimentary gneisses (table 5). Porphyritic igneous rocks of Laramide age form the walls of several deposits in the Jamestown district (see table 6), especially class 1 deposits in the center of the district, and are the dominant wallrocks at the Caribou mine in Boulder County. Bostonite porphyry is a host rock for some deposits in one mine at Central City.

Three of the deposits considered in this report are in sedimentary rocks of Cretaceous age. At the Mann No. 1 and Four Corners mines in Jefferson County the deposits are in sandstone of the Dakota Group, and at the Old Leyden coal mine they are in subbituminous coal and adjacent sandstone within the Laramie Formation.

TABLE 5.-Dominant wallrocks of uranium deposits in Precambrian terranes

\begin{tabular}{|c|c|c|c|c|c|}
\hline \multirow[b]{2}{*}{ District } & \multicolumn{5}{|c|}{ Wallrock } \\
\hline & $\begin{array}{c}\text { Biotite } \\
\text { gneiss } \\
\text { and schist }\end{array}$ & $\begin{array}{l}\text { Calc-silicate } \\
\text { gneiss and } \\
\text { garnetiferous } \\
\text { biotite gneiss }\end{array}$ & $\begin{array}{l}\text { Micro- } \\
\text { cline } \\
\text { gneiss }\end{array}$ & $\begin{array}{l}\text { Amphibo- } \\
\text { liteand horn- } \\
\text { blende gneiss }\end{array}$ & $\begin{array}{c}\text { Granitic } \\
\text { intrusive } \\
\text { rocks }\end{array}$ \\
\hline $\begin{array}{l}\text { Jamestown } \\
\text { Central City } \\
\text { Lawson-Dumont-Fall River } \\
\text { Idaho Springs... } \\
\text { Ralston Buttes. } \\
\text { Idledale. }\end{array}$ & $\begin{array}{l}x \\
x \\
x \\
x \\
x\end{array}$ & $\begin{array}{l}x \\
\bar{x}\end{array}$ & ------- & 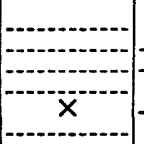 & $\frac{x}{x}$ \\
\hline
\end{tabular}

The wallrocks associated with uranium-bearing base-metal sulfide veins (class 2 deposits) are typically altered to hard bleached sericitized rock in a zone adjacent to the vein and to soft argillized rock in an outer zone (Tooker, 1956; written communication, 1960; Wright, 1954). At Central City, the intensely altered rock of the sericite zone contains quartz, some potassic feldspar, and varying amounts of disseminated pyrite as well as sericite. The argillic zone contains montmorillonite, kaolinite, illite, and mixed-layer clay in various proportions. The total width of the altered-rock envelope varies considerably, depending upon the intensity of alteration, mineralogy of the host rock, and other factors but probably averages about 2 feet. Tooker showed (written communication, 1960) that alteration at Central City probably was partly contemporaneous with the deposi- 
tion of pitchblende, the earliest vein mineral, and that it largely preceded deposition of the sulfide minerals.

The alteration associated with class 3 uranium deposits has not been studied quantitatively but is known to be dominantly propylitic. At the Schwartzwalder mine in the Ralston Buttes district, alteration was confined largely to breccia fragments within and immediately adjacent to uranium-bearing ore. The fragments are altered to finegrained aggregates of quartz, ankerite, clay minerals, and chlorite. Wallrocks of various composition, but dominantly garnetiferous biotite-quartz gneisses, are altered and bleached where fractured or brecciated and near ore but are relatively unaltered in the less intensely fractured and weakly mineralized areas. Thus alteration seems spatially related to the occurrence of uranium. At the Union Pacific deposit, breccia fragments of hornblendic rocks within a pitchblendebearing vein are altered to chlorite and hematite, as determined megascopically. Adams and Stugard (1956c) have classed this alteration at the Union Pacific deposit as propylitic and believe it was nearly contemporaneous with deposition of pitchblende. Hematite formed both in the vein and in the vein walls at the propylitic stage, and potassic feldspar and ankerite formed nearly contemporaneously with the hematite. This occurrence of hematite is unusual among the uranium veins in the Front Range, but is similar to occurrences in the Goldfields region of Saskatchewan, Canada (Lang, 1952; Robinson, 1955), and at Joachimsthal and Johanngeorgenstadt, Czechoslovakia (Everhart and Wright, 1953). The sparsity of hematite in the uranium vein deposits of the Front Range suggests that, contrary to some published views (Nininger, 1954, p. 27-28), hematite is not necessarily a characteristic feature of wallrock alteration associated with vein uranium deposits.

\section{LOCAIIZATION OF DEPOSITS}

The factors that localized the uranium deposits varied from one deposit to another. Fundamentally, because the primary uranium minerals were deposited principally as open space fillings, localization depended mainly on structural controls that provided space for deposition, but locally it may also have been related to chemical controls that governed precipitation. A third and interrelated factor, proximity to source or sources of the ore-forming fluid, is briefly discussed in the section on genesis.

The uranium deposits occur locally in each of the major fault sets known in the central part of the Front Range, but in any particular area they are dominantly in one set. Deposits in the foothills area, for example, are in the breccia reef faults, the dominant fracture set in this part of the range. They typically occur in the subsidiary rather 
than the main faults or reefs and generally in those segments of the fault zones that are complexly broken and consist of numerous branching and intersecting fractures. Within the mining districts in the mineral belt, on the other hand, the deposits are found characteristically in several sets of fractures. In the Central City and adjacent districts, primary uranium deposits occur in all but one of the five recognized sets of faults and commonly in two or more intersecting faults (Sims and others, 1963). About 70 percent of the significant deposits are in veins that strike east-northeast or northeast, 10 percent are in veins that strike east, 15 percent are in veins that strike northwest (related to breccia reef faults), and 5 percent are in lowangle veins related to the northwestward-trending faults. The numerous deposits in the Jamestown district likewise occur in several fault sets, and at places, as the Fair Day mine, are in two or more intersecting faults.

The structural controls that localized the uranium deposits are similar to those that controlled deposition of the gold- and silverbearing sulfide ores of the mineral belt, as described by Lovering (1942, p. 81-92) and others. Uranium ore bodies related to vein junctions or intersections and to curvature in the fault surfaces are common in the mineral belt and are present to a lesser degree in the foothills area. Deposits related to cymoid fractures or combinations of fractures are common in the breccia reefs and related fault systems in the foothills area but uncommon in the mineral belt. Classic examples of cymoid fractures that localize ore shoots can be seen in several mines in Jefferson County, as the Foothills mine at Idledale (fig. 25) and the Schwartzwalder mine in the Ralston Buttes district.

Many of the uranium deposits in the central part of the Front Range are localized by the more brittle rocks. Garnetiferous gneiss is a particularly favorable wallrock. In the Fall River area in Clear Creek County, for example, deposits at the Almaden and nearby Golconda and Mary mines are confined to those segments of the veins that have walls composed of garnetiferous calc-silicate gneiss, which is in layers a maximum of a few tens of feet thick. Less competent strongly foliated biotite gneisses interfolded with the garnetiferous gneisses enclose barren parts of the veins. Similarly, deposits at the Schwartzwalder and other mines in the Ralston Buttes district occur mainly between walls of competent garnetiferous biotite-quartz gneiss, calc-silicate gneiss, hornblende gneiss, or amphibolite; deposits at the Black Knight and Billikin lodes occur mainly between walls of magnetite-bearing garnet gneiss, which forms a thin layer in biotite gneiss. Microcline gneiss localizes ore in some veins in the Central City district, and pegmatite localizes ore in veins cutting biotite gneisses at several localities. 
In some deposits, both the structure and the lithologic character of the wallrocks were important factors in localizing ore bodies. Ore shoots in the Carroll vein, in the Central City district, for example, plunge nearly parallel to the lithologic layering of the wallrocks (Sims, 1956, p. 751-753). Deflections of the Carroll fault as it broke through from one layer of rock to another evidently caused crackling, brecciation, and splitting in the more competent layers, and ore shoots were localized in the fracture zones parallel to the layering.

The close association of many uranium deposits with iron- and calcium-rich host rocks suggests a chemical control of uranium deposition, as postulated by Adams and Stugard (1956a, 1956b, 1956c) for deposits in hornblende gneiss in the Golden Gate Canyon area and as postulated by Hawley and Moore (1955) for deposits in calc-silicate gneiss in the Fall River area. Adams and Stugard (1956c, p. 200-207) believed that uranium was precipitated by a chemical interaction between the host rocks and the ore-forming solutions. Ferrous iron in hornblende and other iron-bearing minerals was oxidized to hematite, and this reaction was accompanied by deposition of uranium as pitchblende, presumably through reduction of $\mathrm{U}^{+6}$ ions to $\mathrm{U}^{+4}$ ions. If operative, such a mechanism for precipitation of pitchblende was probably restricted to deposits that have a carbonate gangue, for deposits in quartz gangue do not show any preference for iron-rich host rocks. .

\section{SUPERGENE AITERATION}

All the uranium deposits in the Front Range show supergene alteration in some degree. The nature of the alteration differs in the various kinds of deposits, depending on the mineralogy of the veins and the host rocks. At one extreme, the primary ore bodies grade upward into a relatively simple assemblage of secondary uranium minerals which extend to (or near) the surface, and at the other extreme, the primary bodies are capped by a nearly barren leached zone.

The behavior of uranium under oxidizing conditions is well known as the result of several recent studies (Barton, 1956; Garrels and Christ, 1959; Gritsaenko and others, 1958; Lovering, 1955; McKelvey and others, 1955; Phair and Levine, 1953; and Walker, 1963) and will not be discussed in detail here. In brief, the primary quadrivalent uranium minerals are changed in an oxidizing environment successively to amorphous $\mathrm{UO}_{3}$ (sooty pitchblende), to uranyl ions in solutions, and thence to diverse uranyl compounds or to adsorbed uranyl ions (Garrels and Christ, 1959, fig. 13). The nature of the uranyl compounds and their abundance depend primarily upon the available anions and cations and the effectiveness of the neutralizing agents in 
precipitating uranium from solution. Commonly the alteration products are distributed zonally according to the stabilities and solubilities of these products (Stugard and others, 1952).

\section{OXIDATION ZONES OF URANIUM-BEARING BULFIDE VEINS}

The character and degree of alteration of uranium-bearing sulfide veins by supergene solutions differed from vein to vein, depending mainly upon the amount of $\mathrm{H}_{2} \mathrm{SO}_{4}$ generated from oxidation of pyrite. Alteration of uranium-bearing base-metal sulfide veins that contain pitchblende, galena, sphalerite, copper sulfides, and sparse pyrite, typically yielded a nearly barren leached zone from the surface to depths of 10-30 feet. Below this, hexavalent uranium minerals form a zone of variable vertical extent, and this grades downward through a narrow zone of soft porous and sooty pitchblende into the primary hard black uranium ore. The secondary (hexavalent) minerals concentrated in and adjacent to the veins are commonly torbernite, metatorbernite, autunite, and kasolite. They occur to average depths of about 100 feet, but may be found as much as 150 feet below the surface. The interface between the zone of secondary minerals and the underlying primary ore coincides closely with the mean water table, which also marks the approximate lower limit of hydrous iron oxides. The secondary uranium minerals are not confined to the veins but occur also in fractures and in disseminated grains in the wallrocks. Replacement deposits in the wallrocks have been mined on a small scale in the Central City district (Sims and others, 1955, 1963). At several localities in the Front Range, metatorbernite or torbernite is disseminated in altered biotite gneiss or amphibolite. The uranium minerals are interleaved with clay minerals and also coat fractures in the altered rocks. The tenor of such deposits is low, averaging less than 0.10 percent uranium, but some of the material can be hand sorted to a grade of 0.20 percent or more. The more soluble uranium sulfate and carbonate minerals are not stable in the oxidized zones of the veins, but they occur as encrustations on mine walls and mine timbers, where they formed by evaporation of uraniferous mine waters.

In uranium veins that contained abundant pyrite, such as many on Quartz Hill in the Central City district, most metallic constituents were removed in the supergene zone, leaving a virtually barren, leached capping. Beneath this capping is a narrow zone in which the primary pitchblende is changed to soft, sooty pitchblende, but colored hexavalent secondary minerals are absent. The sparse uranium that remains in the oxidized zone is largely adsorbed on limonite. Such intense alteration is accomplished by the free sulfuric acid generated from pyrite in the supergene zones. In the absence of neutralizing 
agents, the acid waters leach uranium from the vein and discharge it into surface waters.

The changes that accompany alteration of hard pitchblende to soft, sooty pitchblende in the weathered zone have been noted at several mines in the Central City district and adjacent areas. The change in physical appearance generally occurs in place with little migration of the powdery secondary phase. It is accompanied by a change in the unit cell dimension of the mineral and by a loss of definition of X-ray diffraction patterns. The unit cell edge, as measured in selected samples from the Central City and adjacent districts, ranges from 5.461 angstrom units in hard pitchblende to 5.400 angstrom units in soft porous material; according to the data of Brooker and Nuffield (1952, fig. 22), these values indicate a range in uranium oxidation state from $\mathrm{UO}_{2.03}$ to $\mathrm{UO}_{2.52}$. A few samples of sooty pitchblende gave no powder pattern, and according to Brooker and Nuffield they should contain 85 percent or more of their total uranium as $\mathrm{UO}_{3}$.

\section{OXIDATION ZONES OF VEINS CONTANNING SPARSE SULFIDES}

Veins composed dominantly of primary uranium minerals and gangue (class 3 deposits) are less intensely leached than sulfide-rich veins in the supergene zone, and locally they contain some uranyl hydroxide hydrates.

In the Ralston Buttes district, Bird and Stafford (1955, p. 82) found that uranium has been leached from the veins to depths of 10-20 feet below the surface, and they suggest that at depths of about 100 feet the veins probably were enriched with "secondary" pitchblende. Evidence for leaching and enrichment of uranium is (a) an increase in the ratio of chemical uranium to equivalent uranium with depth, and (b) a succession of changes in mineralogy with depth. Below the leached outcrops is a zone characterized by completely oxidized uranium minerals; then a zone containing mixed hexavalent uranium minerals and sooty pitchblende; then a zone of mixed sooty and massive pitchblende; and finally, the unaltered primary pitchblende.

Hydration of pitchblende, probably with only partial oxidation, has been observed near the surface at two mines in the Ralston Buttes district (Adams and others, 1953, p. 16). The hydrated pitchblende is associated with malachite and azurite. Becquerelite has been identified from a similar environment in the Billikin lode in southern Jefferson County (Walker and Adams, 1963). Possibly the transformation from primary pitchblende to these uranyl hydroxide hydrate minerals is largely by pseudomorphous replacement without an intervening uranyl ion solution stage. 
$\mathbf{A G E}$

Seemingly reliable age data have been obtained from uraninite from two areas in the Front Range, the Central City district, Gilpin County, and the Ralston Buttes district, Jefferson County. Determinations by the $\mathrm{Pb}^{206} / \mathrm{U}^{238}$ method on uraninites from the Wood and Iron mines in the Central City district gave ages ranging from 57 to 70 million years after appropriate lead corrections. Determinations by the $\mathrm{Pb}^{210}$ method on uraninite from the German mine gave an age of $58 \pm 3$ million years (Faul and others, 1954, table 9, p. 263). Earlier, Holmes (1947, p. 145) determined two pitchblendes (uraninite) from the Central City district to be 57.3 and 59.8 million years old $\left(\mathrm{Pb}^{206} / \mathrm{U}^{238}\right.$ method). Determinations on uraninite from the Mena mine in the Ralston Buttes district (L. R. Stieff and T. W. Stern, oral communication, 1959) gave:

$\begin{gathered}\text { Method } \\ \text { (in million years) }\end{gathered}$
$\mathrm{Pb}^{208} / \mathrm{U}^{239}$
$\mathrm{~Pb}^{207} / \mathrm{U}^{235}$

Thus, although the pitchblende from the Ralston Buttes district appears to be slightly older than that from Central City, the ores of both localities are generally similar in age and presumably are products of the same general period of hydrothermal activity. According to the absolute time scale of Holmes (1959, p. 183), the mineralization is Late Cretaceous or early Tertiary, and thus Laramide, in age.

\section{REGIONAL ZONING RELATIVE TO THE MINERAL BELT}

The distribution of the known uranium deposits together with observed systematic changes in their size and character indicate a zonal arrangement with respect to the mineral belt.

The principal deposits in the central part of the Front Range occur either within mining districts of the mineral belt or in a strip of ground to the southeast of the belt, in the foothills area. The deposits within the belt are scattered through many of the areas that contain goldand silver-bearing sulfide veins and commonly occur in the gold and silver veins. Those in the foothills area, although widely dispersed, are mainly 7-20 miles distant from the southeast margin of the belt, as outlined in figure 2. The largest deposits, as the Schwartzwalder and adjacent mines in the Ralston Buttes district, are 8-10 miles southeast of the belt. The somewhat smaller deposits at Idledale are about 15 miles from the belt, and scattered minor deposits occur as far as 30 miles southeast of the belt. Of three other large uranium mining districts in Colorado (outside of the Colorado Plateau), 
two-the Marshall Pass district in Gunnison, Saguache, and Chaffee Counties (Del Rio, 1960, p. 357-359) and the Cochetopa district in Saguache County (Del Rio, 1960)-lie near and southeast of the mineral belt, in a position comparable to the deposits in Jefferson County. The third, the Tallahassee Creek district in Fremont County (Del Rio, 1960, p. 359-361) lies far outside the mineral belt, although southeast of it.

Only a few uranium deposits are known on the northwest side of the mineral belt. The reason for this is not fully understood, but it is possibly significant that dikes also are concentrated along the southeast side of the mineral belt, and that among these are some of the youngest porphyries. This subject is considered in the discussion of genesis, below.

Systematic changes in the mineralogy of the deposits also reflect a general zonal pattern. The changes are most evident along the persistent breccia reefs and related faults, which extend across the full width of the mineral belt and for several miles on either side. The breccia reefs are characterized by a gangue of quartz, hematite, and fluorite where they transect the mineral belt. Toward the southeast, this assemblage gives way to dominant ankerite and potassic feldspar, which, along with quartz, form the gangue in all the important uranium deposits in the foothills area. The transition from one assemblage to another is not sharp, so far as known, but apparently takes place near the margins of the mineral belt. The change in gangue is accompanied by a parallel change in metallic constituents. Within the mineral belt, the northwestward-trending breccia-reef fractures are generally barren, but at places they contain ore minerals characteristic of whatever mining districts they cross. Thus, where the faults cross the Idaho Springs and Central City districts they locally contain gold- and silver-bearing pyrite and copper-lead-zinc ores (Sims and others, 1963); where they cross the Boulder tungsten district they locally contain tungsten and silver ores (Lovering and Tweto, 1953, p. 55-57), and where they transect the Gold Hill district they locally contain pyritic gold and gold telluride ores (Goddard, 1940). A specific example of the changes in mineralization along a single breccia reef zone is given by the Rogers reef. This breccia reef or fault zone can be traced discontinuously across the full width of the mineral belt (see Lovering and Goddard, 1950, pl. 2) and southeastward to the mountain front, a total linear distance of more than 20 miles. In the Ward district, near the northwestern edge of the mineral belt, the reef fractures contain gold, silver, and lead, and locally sparse copper, zinc, and tungsten (Lovering and Goddard, 1950 , p. 206-208). Farther southeast, the reef crosses the middle 
part of the Boulder County tungsten district (Lovering and Tweto, 1953 , p. 56-57) and there contains some tungsten along with sparse and local iron, copper, lead, zinc, and silver. Southeast of the Boulder County tungsten district, the reef is generally barren for a distance of about 12 miles and then crosses the Ralston Buttes district, where it contains the important uranium deposits of the Schwartzwalder and adjacent mines.

In general, systematic changes in structure and texture accompany the changes in mineralogy. Uranium deposits in the mineral belt have structures and textures typical of mesothermal veins (Lindgren, 1933, p. 529-532), whereas those in the foothills area are epithermal or transitional to epithermal. The deposits in the mineral belt formed mainly by filling spaces along moderately regular fissures but also in part by replacing the wallrocks. They have moderately to strongly altered wallrocks, and vugs in the ore are generally small. Considerable variation in the character of the veins occurs as a result of zoning, however, and at the Fair Day mine in the Jamestown district, the deposits are epithermal in character. The Fair Day and a few similar veins contain a simple assemblage of minerals, have abundant and locally large cavities, and contain crustified ores with conspicuous colloform structures. Epithermal deposits are more characteristic of the foothills area, however. They include the important deposits in the Idledale district and some in Golden Gate Canyon. Many of these deposits are extremely vuggy and formed almost entirely by crustification. The deposits at the Schwartzwalder and adjacent mines in the Ralston Buttes district appear to be transitional. They contain moderate amounts of base-metal sulfides and sulfosalts and are not conspicuously vuggy, but they do not have the intensely altered walls characteristic of the typical mesothermal veins within the mineral belt.

\section{GENESIS}

The apparent zonal pattern of the uranium deposits, as well as other considerations, lead us to conclude that all the uranium deposits in the central part of the Front Range probably were derived from a common source located in the vicinity of the mineral belt. Hydrothermal solutions from this source presumably carried uranium and other metals upward and outward along channelways afforded by the fracture system. These solutions deposited some uranium in the fissures within the mineral belt but carried most of it out of the belt and deposited it in the foothills area.

The regional studies of Phair (1952) and the detailed investigations of Sims and others (1963) indicate that the uranium deposits in the 
central part of the Front Range mineral belt probably were derived from the magma (or magmas) that consolidated to yield the Laramide porphyritic igneous rocks. These deposits are typically associated with sulfide ores and are located at intrusive centers of the porphyries. In some districts uranium probably was derived directly from the same moderately deep-seated magma source as the sulfide ores, and in others it probably was derived from relatively shallow crystallizing bodies of quartz bostonite porphyry. The latter source seems most important at Central City. In addition to a close spatial and temporal association of ores and igneous rocks at Central City (commonly accepted as evidence of genetic relationship), several other lines of evidence support this conclusion: (a) a demonstrable enrichment of uranium (and thorium) in successively younger members of the porphyritic igneous sequence (Wells, 1960, p. 266-269), and thus a likely source of uranium for hydrothermal transport; (b) intimate association of uranium and zirconium in both the radioactive porphyries and the primary uranium ore minerals; and (c) close grouping of many uranium deposits adjacent to exposed bodies of quartz bostonite porphyry, the youngest of the intrusive rocks emplaced prior to formation of the ores.

The data on zirconium content of pitchblende constitute indirect but strongly suggestive supporting evidence of a common source for the uranium throughout the central part of the range. Except in two localities, all pitchblende that has been analyzed contains unusually high amounts of zirconium (table 3). Most samples contain more than a percent, and some contain several percent of zirconium. As zirconium in such concentrations has not been reported from pitchblendes in other areas in the United States (Palache and others, 1944, p. $612-613$; Frondel, 1958, p. 16-20), it seems to be a peculiarity of the Front Range ores and suggests that they all came from a common source. If the zirconium were merely picked up from the wallrocks it should be more prevalent in pitchblendes in similar rocks in other places.

The origin of the uranium deposits in the foothills area is less certain, as these deposits are not directly associated with Laramide intrusive rocks. They are linked to the deposits within the mineral belt by similarity in age, however, and probably were derived from the same general source.

In summary, we infer that the uranium-bearing solutions moved upward and outward from a source beneath the present mineral belt and deposited uranium at appropriate temperatures and pressures in structurally or chemically favorable sites. Within the mineral belt, 
the solutions probably rose along many openings in the complex fault network, but dominantly along the larger fundamental fractures such as the northwestward-trending breccia reefs and related faults. The solutions either were mixed with polymetallic sulfide-bearing solutions at the source or mingled with them in transit and precipitated uranium in the vein fissures with sulfides dominantly in structurally controlled sites. Some of the more persistent and continuous breccia reef faults that transect the mineral belt and extend for miles in either direction provided channelways along which the solutions could also move far outside the mineral belt. Uranium, being generally more mobile than other cations in solution, was carried far beyond the limits of the mineral belt as we now know it and was precipitated in and along the major fault systems, along with sparse sulfides and gangues. In this environment, chemically favorable wallrocks perhaps were as effective as structural sites in controlling the deposition of uranium, as postulated by Adams and Stugard (1956c).

Data that directly indicate the temperatures at which the primary uranium minerals formed are not available for any locality. We know from studies of sphalerite geothermometry in the Central City district (Sims and Barton, 1961) that primary uranium minerals occur mainly in veins that formed in the range $300^{\circ}-500^{\circ} \mathrm{C}$, but as the pitchblende formed before the sphalerite (Sims, 1956a), it may have crystallized at somewhat different temperatures. In the foothills area, sphalerite from the Schwartzwalder mine contains 0.26 percent iron and probably formed at a temperature of between $100^{\circ} \mathrm{C}$ and $430^{\circ} \mathrm{C}$. (See fig. 5, Sims and Barton, 1961.) The associated pitchblende possibly formed at temperatures in the lower part of this permissive range. Other deposits in the foothills area can be presumed on the basis of similarity to the Schwartzwalder deposits to have formed at similar or still lower temperatures.

\section{FUTURE OF REGION}

It seems probable that the Front Range will continue to be a substantial source of uranium ore in future years, and additional significant deposits should be found. Most of the production and most of the new discoveries can be expected in the foothills area, southeast of the mineral belt, along and adjacent to the major northwestwardtrending faults. Intersections of these faults with iron-rich Precambrian metamorphic rocks are favorable for ore occurrences, as suggested earlier by Adams and Stugard (1956c, p. 208), but prospecting should by no means be confined to such rocks. Sulfide-bearing rocks and the relatively competent rocks in any lithologic succession 
are also favorable host rocks. The area to the northwest of the mineral belt has thus far been unproductive, but the possibilities of finding uranium ore occurrences there have not yet been exhausted (Sims, 1956b).

Within the mineral belt, the most favorable areas for substantial uranium production are near the margins of the base- and preciousmetal mining districts, in areas that have the relation the Fair Day mine has to the Jamestown mining district. Small quantities of uranium ore probably will continue to be found in the main mining districts of the mineral belt, principally in association with sulfide ores, but at 1961 prices, such ore could be mined only as a byproduct of gold and silver ores. Accordingly, this source cannot be expected to be of much significance economically. In general, veins of the epithermal class appear to be the most promising sources of uranium ore. Most of the uranium ore mined thus far in the Front Range has come from veins of this type or from closely related veins with some mesothermal characteristics.

\section{DESCRIPTION OF PRINCIPAL MINES}

Most of the uranium deposits and mines considered in this report are in the central part of the Front Range, in Boulder, Clear Creek, Gilpin, and Jefferson Counties. Production data for the four counties are given in table 1. Additional data for some mines and districts are shown in tables 8,9 , and 10 .

\section{BOULDER COUNTY}

Uranium-bearing veins are widespread in the mountainous segment of Boulder County but are concentrated in the Jamestown and Gold Hill districts and to a lesser extent in the Caribou-Grand Island and Eldora districts (table 6). The largest known deposits are in the Jamestown district. The Fair Day mine, in the western part of the Jamestown district, has yielded substantial amounts of uranium ore, and the Lulu B lode of the Victory group and the Golden Age mine have yielded lesser amounts. Several tons of uranium ore were recovered from a tailings pond in the district in 1955 . In addition, small quantities have been shipped from the Caribou and Sisk mines in other parts of the county. The total value of the uranium ores shipped from the county through 1960 is estimated at about $\$ 400,000$. 
TABLE 6.-Uranium vein deposits in Boulder County, Colo.

[Analyses by U.S. Geol. Survey]

\begin{tabular}{|c|c|c|c|c|c|c|c|}
\hline \multirow{2}{*}{ Mine or locality } & \multirow{2}{*}{$\begin{array}{l}\text { Dis- } \\
\text { trict1 }\end{array}$} & \multicolumn{3}{|c|}{ Location } & \multirow{2}{*}{ Mine workings } & \multirow{2}{*}{$\begin{array}{l}\text { Classifica- } \\
\text { tion of } \\
\text { deposit }\end{array}$} & \multirow{2}{*}{ Wallrock } \\
\hline & & Sec. & $\mathbf{T}$ & R. & & & \\
\hline Argo & $\mathbf{J}$ & 13 & $2 \mathrm{~N}$ & $72 W$ & Shaft; 5 levels...... & 1 & $\begin{array}{l}\text { Silver Plume } \\
\text { Granite. }\end{array}$ \\
\hline Bell group... & G & 22 & $1 \mathrm{~N}$ & $71 W$ & 150-ft adit_........ & $\overline{2}$ & $\begin{array}{l}\text { Boulder Creek } \\
\text { Granite. }\end{array}$ \\
\hline Black Cloud. & G & 12 & $1 \mathrm{~N}$ & $72 W$ & $\begin{array}{l}\text { Adit; } 1,500 \mathrm{ft} \\
\text { drifts. }\end{array}$ & 2 & Do. \\
\hline Blue Jay.-.-. & $\mathbf{J}$ & 30 & $2 \mathrm{~N}$ & $71 W$ & Shaft; 2 levels...... & 1 & $\begin{array}{c}\text { Granodiorite } \\
\text { (Laramide). }\end{array}$ \\
\hline Brown Spar . . ........ & $\mathbf{J}$ & 24 & $2 \mathrm{~N}$ & $72 W$ & Shaft; 3 levels..... & 1 & Do. \\
\hline Burlington & $\mathbf{J}$ & 24 & $2 \mathbf{N}$ & $72 W$ & Shaft; 4 levels..... & 1 & Not known. \\
\hline Caribou $3 . \ldots . . . . . .$. & $\mathrm{C}$ & 8 & 18 & $73 W$ & Shaft; 14 levels..... & 2 & $\begin{array}{c}\text { Monzonite } \\
\text { (Laramide). }\end{array}$ \\
\hline Copper Blush......... & $\mathbf{J}$ & 17 & $2 \mathbf{N}$ & $71 W$ & $\begin{array}{l}\text { Shaft; several } \\
\text { levels. }\end{array}$ & 1 & $\begin{array}{l}\text { Silver Plume } \\
\text { Granite. }\end{array}$ \\
\hline Emmett.............. & $\mathbf{J}$ & 24 & $2 \mathbf{N}$ & $72 W$ & $\begin{array}{l}\text { Shaft; } 10 \text { levels; } \\
\text { crosscut adit; } \\
\text { opencut. }\end{array}$ & 1 & Do. \\
\hline Energy ... & $\mathbf{J}$ & 10 & $2 \mathrm{~N}$ & $71 W$ & Pits and trenches. & $\overline{1}$ & $\begin{array}{c}\text { Granodiorite } \\
\text { (Laramide). }\end{array}$ \\
\hline Fair Day ${ }^{s}$ & $\mathbf{J}$ & 23 & $2 \mathrm{~N}$ & $72 W$ & $\begin{array}{l}\text { Incline; } 1,100 \text { ft } \\
\text { drifts; adit. }\end{array}$ & 3 & $\begin{array}{l}\text { Graphitic biotite } \\
\text { gneiss; Silver } \\
\text { Plume Granite. }\end{array}$ \\
\hline Gibson..... & $\mathbf{J}$ & 12 & $2 \mathrm{~N}$ & $72 W$ & Not known & $\begin{array}{c}\text { Not } \\
\text { known. }\end{array}$ & Not known. \\
\hline Golden Age........ & $\mathbf{J}$ & 20 & $\overline{2 N}$ & $71 W$ & Shaft; adits .... & $\overline{2}$ & $\begin{array}{l}\text { Silver Plume } \\
\text { Granite; quartz } \\
\text { monzonite } \\
\text { porphyry. }\end{array}$ \\
\hline Golden Reward...... & C & 15 & is & $73 \mathrm{~W}$ & Adit; 322 ft drifts.- & 2 & Gneiss, pegmatite. \\
\hline Goldsmith Maid..... & $G$ & 13 & $1 \mathrm{~N}$ & $72 \mathrm{~W}$ & Adit ....... & 2 & $\begin{array}{l}\text { Boulder Creek } \\
\text { Granite. }\end{array}$ \\
\hline King tunnel & G & 21 & $1 N$ & $71 \mathrm{~W}$ & Adit; drifts.......... & 2 & Do. \\
\hline Lady Bug-...-.. & $\mathbf{J}$ & 20 & $2 \mathrm{~N}$ & $71 W$ & Small........ & $\begin{array}{l}\text { Not } \\
\text { known. }\end{array}$ & Not known. \\
\hline Lehman Lode.......... & $\mathrm{J}$ & 19 & $2 \mathrm{~N}$ & $71 W$ & 67-ft adit............ & 1 & $\begin{array}{l}\text { Quartz monzonite } \\
\text { porphyry } \\
\text { (Laramide). }\end{array}$ \\
\hline Lucky Lode............. & $\mathbf{J}$ & 20 & $2 \mathbf{N}$ & $71 W$ & Not known $\ldots$ & $\begin{array}{l}\text { Not } \\
\text { known. }\end{array}$ & Not known. \\
\hline Marc. No. 1.... & $\mathbf{J}$ & $\begin{array}{l}13 \\
24\end{array}$ & $2 \mathrm{~N}$ & $72 W$ & -....do_... & $\begin{array}{l}\text { Not } \\
\text { known. }\end{array}$ & Do. \\
\hline
\end{tabular}

See footnotes at end of table. 
TABLE 6.-Uranium vein deposits in Boulder County, Colo.-Continued

\begin{tabular}{|c|c|c|c|c|c|c|c|}
\hline \multirow{2}{*}{ Mine or locality } & \multirow{2}{*}{ Dis- } & \multicolumn{3}{|c|}{ Location } & \multirow{2}{*}{ Mine workings } & \multirow{2}{*}{$\begin{array}{c}\text { Classifica- } \\
\text { tion of } \\
\text { deposit }\end{array}$} & \multirow{2}{*}{ Wallrock } \\
\hline & & Sec. & $\mathbf{T}$. & $\mathbf{R}$. & & & \\
\hline Miller Group 3........ & $\mathbf{J}$ & 12 & $2 \mathrm{~N}$ & $72 W$ & Small.............. & 3 & Granite. \\
\hline Miranda A. Johnson. & $\mathbf{J}$ & 18 & $2 \mathrm{~N}$ & $71 W$ & - & 3 & Silver Plume granite. \\
\hline Nations Treasure.... & $\mathbf{J}$ & 24 & $2 \mathrm{~N}$ & $72 W$ & $\begin{array}{l}\text { Crosscut adit; } \\
\text { 200-ft drifts. }\end{array}$ & 1 & Do. \\
\hline No Sopi............. & $\mathrm{J}$ & 20 & $2 \mathrm{~N}$ & $71 \mathrm{~W}$ & Small_................ & Not known & Monzonite(?). \\
\hline Orion......... & $\mathbf{J}$ & 24 & $2 \mathrm{~N}$ & $72 W$ & $\begin{array}{l}2 \text { shafts; drifts; } \\
\text { opencuts. }\end{array}$ & 1 & $\begin{array}{c}\text { Granodiorite } \\
\text { (Laramide). }\end{array}$ \\
\hline Poorman.-..-..-... & $\mathbf{J}$ & 30 & $2 \mathrm{~N}$ & $71 \mathrm{~W}$ & Shaft; 100 -ft drifts & 1 & Do. \\
\hline Pueblo Belle.... & $\mathbf{B}$ & $\overline{31}$ & $1 \mathrm{~N}$ & $71 W$ & Adit_............... & 2 & $\begin{array}{l}\text { Boulder Creek } \\
\text { Granite. }\end{array}$ \\
\hline Rose Mary ...... & $\overline{-\cdots}$ & 4 & $3 \mathbf{N}$ & $70 W$ & Small.............. & Not known & $\begin{array}{l}\text { Sandstone of Dakota } \\
\text { Group. }\end{array}$ \\
\hline Shirley............ & C & 19 & $1 \mathrm{~S}$ & $73 W$ & Adit; $600-\mathrm{ft}$ drifts.- & 2 & $\begin{array}{l}\text { Monzonite por- } \\
\text { phyry (Laramide). }\end{array}$ \\
\hline Sisk ${ }^{3} \ldots \ldots$ & $-\cdots$ & 2 & $3 N$ & $71 W$ & $\begin{array}{l}\text { Incline; 150-ft } \\
\text { drifts. }\end{array}$ & 3 & $\begin{array}{l}\text { Garnetiferous bio- } \\
\text { tite gneiss. }\end{array}$ \\
\hline Terror-Roseberry -..-- & C & 21 & $1 \mathrm{~S}$ & $73 W$ & $\begin{array}{l}\text { 700-ft adit; 200-ft } \\
\text { shaft. }\end{array}$ & 2 & Biotite gneiss. \\
\hline Unknown (22)10 & $\mathbf{G}$ & 18 & $1 \mathrm{~N}$ & $71 W$ & Drifts.............. & 2 & $\begin{array}{c}\text { Boulder Creek } \\
\text { Granite. }\end{array}$ \\
\hline$(24)^{10} \ldots$ & G & 17 & $1 \mathrm{~N}$ & $71 W$ & Adit; drifts......... & 2 & Do. \\
\hline$(35)^{10} \ldots \ldots$ & $G$ & 7 & $1 \mathrm{~N}$ & $71 \mathrm{~W}$ & Adit................. & 2 & Do. \\
\hline$(36)^{10} \ldots \ldots$ & G & 12 & $1 \mathrm{~N}$ & $72 \mathrm{~W}$ & Adit; drifts.......... & 2 & Do. \\
\hline$(41)^{10}$ & $G$ & 18 & $1 \mathrm{~N}$ & $71 \mathrm{~W}$ & Adit_............ & 2 & Do. \\
\hline$(49)^{10} \ldots$ & $G_{1}$ & 17 & $1 \mathrm{~N}$ & $71 \mathrm{~W}$ & -...do................ & 2 & Do. \\
\hline$(66)^{10} \ldots \ldots$ & G & 8 & $1 N$ & $71 W$ & $\ldots$ do & 2 & Do. \\
\hline$(68)^{10} \ldots \ldots$ & $G$ & 7 & $1 N$ & $71 W$ & $\begin{array}{l}\text { Adit; crosscut } \\
\text { drift. }\end{array}$ & 2 & Do. \\
\hline$(70)^{10} \ldots$ & $G$ & 7 & $1 N$ & $71 \mathrm{~W}$ & Adit: drifts......... & 2 & Do. \\
\hline$(87)^{10} \ldots \ldots$ & $G$ & 13 & 1N & $72 W$ & ....do.......... & 2 & Do. \\
\hline Victory group ${ }^{\prime}$ & $\mathbf{J}$ & $\begin{array}{l}19 \\
30\end{array}$ & $2 \mathrm{~N}$ & $71 W$ & Opencut..... & 3 & $\begin{array}{l}\text { Quartz-biotite gneiss; } \\
\text { Silver Plume } \\
\text { Granite. }\end{array}$ \\
\hline
\end{tabular}

See footnotes at end of table. 
TABLE 6.-Uranium vein deposits in Boulder County, Colo.-Continued

\begin{tabular}{|c|c|c|c|}
\hline Mine or locality & $\begin{array}{l}\text { Strike and dip of } \\
\text { vein }\end{array}$ & $\begin{array}{l}\text { Uranium-bearing } \\
\text { minerals }\end{array}$ & Associated minerals \\
\hline Argo-..- & N. $80^{\circ}$ E.; steep 8 & Uraninite(?) & $\begin{array}{l}\text { Galena, pyrite, sphalerite, quartz, } \\
\text { clay minerals. }\end{array}$ \\
\hline Bell group... & Not known.......... & Not known.......... & Quartz, pyrite. \\
\hline Black Cloud. & NE; steep NW $\ldots$ & Pitchblende........... & $\begin{array}{l}\text { Quartz, pyrite, gold, galena, } \\
\text { sphalerite. }\end{array}$ \\
\hline Blue Jay .. & NW; steep... & $\begin{array}{l}\text { Uraninite, } \\
\text { uranothorite. }\end{array}$ & $\begin{array}{l}\text { Fluorite, quartz, pyrite, galena, clay } \\
\text { minerals. }\end{array}$ \\
\hline Brown Spar & N. $75^{\circ}$ E.; steep S... & Not known & Not known. \\
\hline Burlington.. & N. $55^{\circ}$ E.; vertical _ _ & - do......... & $\begin{array}{l}\text { Fluorite, galena, pyrite, quartz, clay } \\
\text { minerals. }\end{array}$ \\
\hline Caribou ${ }^{3}$ & N. $90^{\circ}$ E.; $70^{\circ} \mathrm{S}$ & Pitchblende........... & $\begin{array}{l}\text { Pyrite, galena, sphalerite, chalcopy } \\
\text { rite, ruby silver, native silver, } \\
\text { quartz, carbonate minerals, barite, } \\
\text { argentite. }\end{array}$ \\
\hline Copper Blush. & Not known & Not known. & $\begin{array}{l}\text { Fluorite, pyrite, chalcopyrite, } \\
\text { quartz, chalcedony. }\end{array}$ \\
\hline Emmett.. & $\begin{array}{l}\text { N. } 65^{\circ} \text { W.; steep } \\
\text { NE. }\end{array}$ & $\begin{array}{l}\text { Uraninite(?), } \\
\text { torbernite, } \\
\text { metatorbernite. }\end{array}$ & $\begin{array}{l}\text { Fluorite, pyrite, galena, chalcopyrite, } \\
\text { sphalerite, quartz, chalcedony. }\end{array}$ \\
\hline Energy -....- & N. $15^{\circ}$ W.; $57^{\circ} \mathrm{W}_{\ldots}$ & Not known & Fluorite, quartz, pyrite. \\
\hline Fair Day ${ }^{5}$.- & See text... & $\begin{array}{r}\text { Uraninite, } \\
\text { coffinite. }\end{array}$ & Pyrite, quartz, galena. \\
\hline Gibson_.............. & Not known .......... & Not known & Not known. \\
\hline Golden Age... & $\begin{array}{l}\text { N. } 60^{\circ} \text { E.; } 35^{\circ}-70^{\circ} \\
\text { SE. }\end{array}$ & -...do......... & Pyrite; chalcopyrite. \\
\hline Golden Reward....... & - do do & do............. & Pyrite, quartz. \\
\hline Goldsmith Maid... & N. $50^{\circ}$ E.; $73^{\circ} \mathrm{NW}_{-.}$ & $\begin{array}{l}\text { Pitchblende, } \\
\text { torbernite. }\end{array}$ & $\begin{array}{l}\text { Pyrite, galena, sphalerite, quartz, } \\
\text { gold telluride(?). }\end{array}$ \\
\hline King tunnel... & Not known & Not known . . . . & Not known. \\
\hline Lady Bug.... & N. $50^{\circ} \mathrm{E} . ; 90^{\circ} \ldots \ldots$ & Pitchblende......... & Pyrite and chalcopyrite. \\
\hline Lehman Lode. & $\begin{array}{l}\text { N. } 60^{\circ} \text { W.; } 44^{\circ}-89^{\circ} \\
\text { SW. }\end{array}$ & Not known... & Fluorite, pyrite, clay minerals. \\
\hline Lucky Lode..... & Not known. & 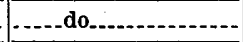 & Not known.. \\
\hline Marc. No. 1.......... & -....do do & ....do................. & Do. \\
\hline
\end{tabular}

See footnotes at end of table. 
DESCRIPTION OF PRINCIPAL MINES

TABLE 6.-Uranium vein deposits in Boulder County, Colo.-Continued

\begin{tabular}{|c|c|c|c|}
\hline Mine or locality & $\underset{\text { vein }}{\text { Strike and dip of }}$ & $\begin{array}{l}\text { Uranium-bearing } \\
\text { minerals }\end{array}$ & Associated minerals \\
\hline Miller Group ${ }^{3}$ & Not known & Autunite............ & Not known.. \\
\hline Miranda A. Johnson.- & 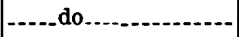 & Meta-autunite......- & Do. \\
\hline Nations Treasure. & $\begin{array}{l}\text { Irregular breccia } \\
\text { zones. }\end{array}$ & Torbernite........... & $\begin{array}{l}\text { Fluorite, quartz, pyrite, galena, } \\
\text { chlorite, clay minerals, chalcedony. }\end{array}$ \\
\hline No Sopi. & Not known & Not known $\ldots \ldots \ldots$ & Quartz; pyrite. \\
\hline Orion. & N. $80^{\circ}$ E.; $80^{\circ}$ N... & -...do... & $\begin{array}{l}\text { Fluorite, quartz, amphibole, hema- } \\
\text { tite, pyrite. }\end{array}$ \\
\hline Poorman. ....... & Not known & -...do.......... & $\begin{array}{l}\text { Fluorite, quartz, carbonate minerals } \\
\text { galena, pyrite, blotite. }\end{array}$ \\
\hline Pueblo Belle.......... & - & - & Quartz, pyrite, ferberite. \\
\hline Rose Mary . . . & NE.; not known.... & $\begin{array}{l}\text { Sooty pitch- } \\
\text { blende(?). }\end{array}$ & Limonite. \\
\hline Shirley........ & N. $30^{\circ}$ E.; $50^{\circ} \mathrm{SE}$ & Pitchblende(?) & Quartz, pyrite. \\
\hline Sisk ${ }^{3}$ & $\mathrm{NW} . ; 50^{\circ}-60^{\circ} \mathrm{SW}$ & - & None. \\
\hline Terror-Roseberry..... & NE.; not known .... & Not known . . . ....... & Quartz, pyrite, gold telluride. \\
\hline Unknown (22) 10 & Not known & - & Not known. \\
\hline$(24)^{10} \ldots \ldots$ & NE.; steep. ......... & (nd do & Do. \\
\hline$(35)^{10} \ldots \ldots$ & E.; steep $\ldots \ldots \ldots$ & - do do................ & Do. \\
\hline$(36)^{10} \ldots \ldots$ & Not known. . . . . & - & -. Do. \\
\hline$(41)^{10} \ldots \ldots$ & - & - & Do. \\
\hline$(49)^{10} \ldots$ & E.: steep......... & - & Do. \\
\hline$(66)^{10} \ldots \ldots$ & NE.; steep............ & - & Do. \\
\hline$(68)^{10} \ldots \ldots$ & NW.; steep. & Pitchblende(?) & Pyrite, quartz. \\
\hline$(70)^{10} \ldots \ldots$ & NE.; steep........... & Pitchblende........-. & Quartz, pyrite, galena. \\
\hline$(87)^{10} \ldots \ldots$ & NE,; steep......... & Not known $\ldots . . .$. & Not known. \\
\hline Victory group $\mathbf{u}$ & E.; steep & Torbernite....... & None. \\
\hline
\end{tabular}

See footnotes at end of table. 
GEOLOGY OF URANIUM DEPOSITS, FRONT RANGE, COLO.

TABLE 6.-Uranium vein deposits in Boulder County, Colo.-Continued

\begin{tabular}{|c|c|c|c|c|}
\hline \multirow{2}{*}{ Mine or locality } & \multirow{2}{*}{ Material sampled } & \multicolumn{2}{|c|}{ Analytical data } & \multirow{2}{*}{$\begin{array}{c}\text { Source of } \\
\text { data }\end{array}$} \\
\hline & & $\begin{array}{l}\text { Equivalent } \\
\text { uranium } \\
\text { (percent) }\end{array}$ & $\underset{\text { (percent) }}{\text { Uranium }}$ & \\
\hline Argo. & $\begin{array}{l}\text { Fluorspar } \\
\text { Sulfides. } \\
\text { Dark fluorite }\end{array}$ & $0.017-0.047$ & $0.004-0.031$ & (2) \\
\hline Bell group. . & $\begin{array}{l}\text { Vein material } \\
\text { Wallrock- }\end{array}$ & $.006-.041$ & $.003-037$ & (2) \\
\hline Black Cloud . ............... & Vein material $\ldots . . . . . .$. & -..... & $.001-.081$ & (2) \\
\hline Blue Jay -. & $\begin{array}{l}\text { Fluorspar } \\
\text { Dark fluorite } \\
\text { Sulfide concentrates }\end{array}$ & $\mid$ & $\begin{array}{l}.037-.045 \\
.018-.084 \\
.035-.11\end{array}$ & (2) \\
\hline Brown Spar................. & Vein material with fluorite. & 029 & $013 \ldots \ldots \ldots$ & (2) \\
\hline Burlington............... & None...................... & .05 (estimate) & $-\ldots \ldots$ & (2) \\
\hline Caribou ${ }^{3}$-.. & Vein $\ldots . . . . \ldots \ldots$ & $\ldots$ & Tr.-7.0........ & (4) \\
\hline Copper Blush................. & Fluorspar. & .022 & .004 & (2) \\
\hline 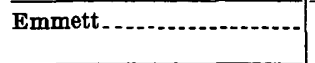 & Fluorite & $.007-052$ & $.004-017$ & (2) \\
\hline Energy & Vein $\ldots . . . . . . . . . . . . . .$. & .019 & $.009 \ldots . . . . . . .$. & (2) \\
\hline Fair Day ${ }^{3} \ldots \ldots$ & (1) & See text.......... & See text.......... & $(8)$ \\
\hline Gibson........................... & -- & & & $(?)$ \\
\hline Golden Age $\ldots . . . . . . . . . .$. & 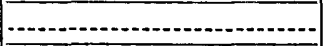 & - & - & $(6)$ \\
\hline Golden Reward..... & Vein $\ldots$ & $.01 \ldots$ & .001 & (2) \\
\hline Goldsmith Maid... & do...................... & $40 \ldots . . . . .$. & .076 & (8) \\
\hline King tunnel... & 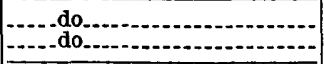 & $.35 \ldots \ldots$ & .069 & (8) \\
\hline Lady Bug & None & $\ldots$ & $-\ldots$ & $(7)$ \\
\hline$\overline{\text { Lehman Lode................ }}$ & Fluorspar & $.007-.035$ & $.003-.005$ & (2) \\
\hline Lucky Lode .............. & 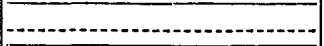 & - & 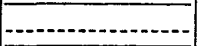 & (7) \\
\hline Marc. No. 1. & & & & (7) \\
\hline
\end{tabular}

See footnotes at end of table. 
TABLE 6.-Uranium vein deposits in Boulder County, Colo.-Continued

\begin{tabular}{|c|c|c|c|c|}
\hline \multirow{2}{*}{ Mine or locality } & \multirow{2}{*}{ Material sampled } & \multicolumn{2}{|c|}{ Analytical data } & \multirow{2}{*}{$\begin{array}{c}\text { Source of } \\
\text { data }\end{array}$} \\
\hline & & $\begin{array}{l}\text { Equivalent } \\
\text { uranium } \\
\text { (percent) }\end{array}$ & $\begin{array}{l}\text { Uranium } \\
\text { (percent) }\end{array}$ & \\
\hline Miller Group 3...- & None... & & & $(\eta)$ \\
\hline Miranda A. Johnson. ...... & Vein & $0.013-0.047 \ldots$ & - & (2) \\
\hline Nations Treasure & $\begin{array}{l}\text { Fluorite with sulfides. } \\
\text { Granite with torbernite... }\end{array}$ & $.035-0.10$ & $0.024-0.075$ & (2) \\
\hline No Sopi & None........ & 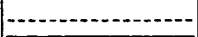 & 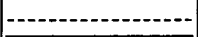 & (7) \\
\hline Orion. & Fluorspar & .01 (estimate) & $.004-.008 \ldots \ldots \ldots$ & $(2)$ \\
\hline Poorman.-- & $\begin{array}{l}\text { Fluorspar } \\
\text { Dump }\end{array}$ & .006 & .022 & ( $\left.{ }^{2}\right)$ \\
\hline Pueblo Belle...... & Quartz vein & 071 & $.005 \ldots$ & (2) \\
\hline Rose Mary & None-1...-. & $-\cdots-$ & - - - n-- & (7) \\
\hline Shirley & Quartz vein & $.009-0.072$ & $.001-.034$ & (2) \\
\hline Sisk ${ }^{3}$ & None & $-\cdots-1$ & - & $(\theta)$ \\
\hline Terror-Roseberry . . & Vein & $.008-0.042 \ldots$ & $.001-.002 \ldots \ldots$. & (2) \\
\hline Unknown (22)10 & (....do do & .012 & 004 & ( $\left.{ }^{8}\right)$ \\
\hline$(24)^{10}-$ & - & $.025 \ldots \ldots \ldots$ & .014 & (8) \\
\hline$(35)^{10} \ldots \ldots \ldots$ & -....do do & 1.24 & $.96 \ldots \ldots \ldots$ & ( \\
\hline$(36)^{10} \ldots \ldots \ldots$ & -....do do & $.050 \ldots$ & .029 & (8) \\
\hline$(41)^{10} \ldots \ldots \ldots$ & -..._do & 11 & $.002 \ldots \ldots$ & (8) \\
\hline$(49)^{10}$ & - & $033 \ldots$ & .017 & (8) \\
\hline$(66)^{10}$ & -.eddo do & $.024 \ldots$ & $.008 \ldots \ldots$ & $(8)$ \\
\hline$(68)^{10} \ldots \ldots$ & Pyrite vein & .015 & $.002-12$ & (8) \\
\hline$(70)^{10}$ & |-1-10 & $-\cdots$ & - & (8) \\
\hline$(87)^{10} \ldots$ & Vein & $32 \ldots \ldots$ & 31 & (8) \\
\hline Victory group ${ }^{11}$-- & Broken ore.. & .19. & .21 & (2) \\
\hline
\end{tabular}

1 J, Jamestown district; G, Gold Hill district; C, Caribou-Grand Island and Eldora districts; B, Boulder County tungsten district; where no letter symbol is shown, no district name is known.

2 R. U. King (written communication, 1956).

Small production of uranium.

Moore, Cavender, and Kaiser (1957).

5 Production is large; see p. 58.

C P. K. Sims.

7 G. W. Walker (oral communication, 1958).

$B$ Campbell (1955).

- F. B. Moore (written communication, 1958)

10 Mine number refers to localities listed by Campbell (1955, fig. 2).

11 Includes Lulu B lode claim. 
Although the history of mining in Boulder County dates from 1860 , uranium was not recognized as a constituent of the ores until 1940 when uraninite was identified in cerite deposits in the northern part of the Jamestown district (Goddard and Glass, 1940). In 1946, pitchblende was noted in some of the fluorspar deposits at Jamestown (Goddard, 1946, p. 19), but the deposits were not systematically investigated for uranium until 1949 when the U.S. Geological Survey examined several mines at Jamestown and elsewhere in the county as a part of its program of uranium investigations in the Front Range (R. U. King, written communication, 1956). In 1951, a detailed study was made of the Caribou mine area (Moore and others, 1957), and in 1953 a thorough reconnaissance was made of the Gold Hill district (Campbell, 1955). From 1956 to 1959 several uranium deposits in the county were examined by personnel of the Defense Minerals Exploration Administration and the U.S. Atomic Energy Commission, and in 1958-59 the important Fair Day mine was studied in detail by the U.S. Geological Survey.

All three of the mineralogic classes of deposits recognized in this report are present in Boulder County. Class 1 deposits occur at Jamestown and are restricted to this district. Class 2 deposits are represented especially by veins in the Gold Hill district, but include others, as the deposits at the Caribou mine in the Caribou-Grand Island district and at the Golden Age mine in the Jamestown district. Class 3 deposits include the Fair Day mine and the Miller group at Jamestown and the Sisk mine northwest of Lyons (fig. 2).

\section{JAMESTOWN DISTRICT}

GENERAL FEATURES

The Jamestown district, the northeasternmost mining district in the Front Range. mineral belt, has yielded important quantities of gold and in recent years substantial amounts of fluorspar and uranium. Total output of the district through 1942 was about $\$ 7$ million (Lovering and Goddard, 1950, p. 256), of which approximately $\$ 3.5$ million has come from gold telluride ores, about $\$ 1.2$ million from pyritic gold ores, about $\$ 1$ million from lead-silver ores, and about $\$ 1.3$ million from fluorspar. Mining of uranium began about 1955 , and by 1960 the output as reported to the U.S. Bureau of Mines totaled 7,993 tons of ore that contained 84,025 pounds of $\mathrm{U}_{3} \mathrm{O}_{8}$.

Geology of the Jamestown district has been described by Goddard (1946) and Lovering and Goddard (1950, p. 255-279). The rocks are primarily Precambrian granite and gneiss intruded by Laramide porphyries, especially granodiorite and sodic granite (fig. 14). Two main fracture systems are recognized. The older and more conspicuous system consists of persistent northwestward-trending breccia 

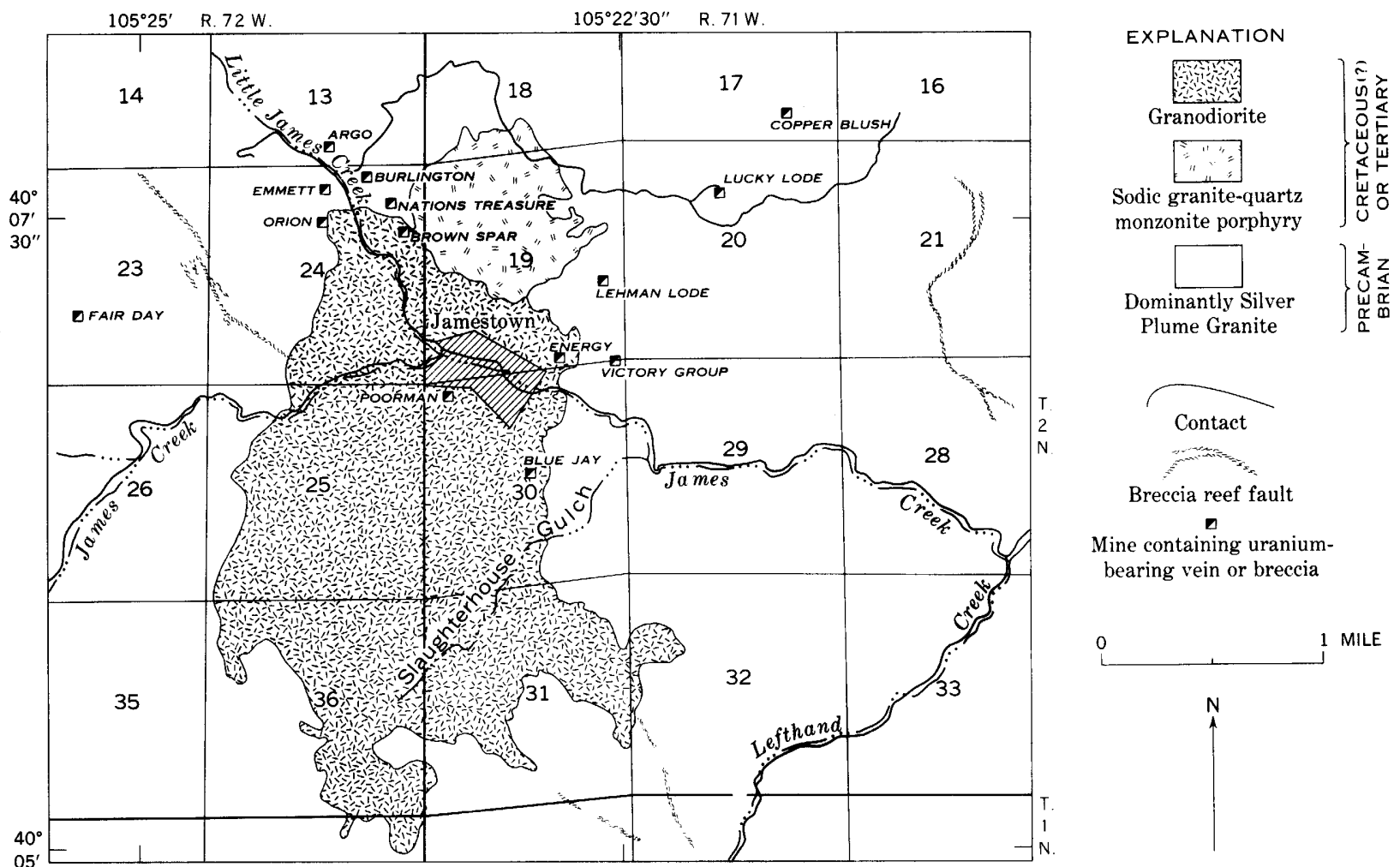

FIGURE 14-Geologic sketch map of the Jamestown district, Colorado, showing locations of principal uranium-bearing vein deposits. Geology after E. N. Goddard (1946). 
reefs and related faults, which predate the Laramide intrusive rocks. The younger system comprises less persistent faults, mainly of northeast trend, that postdate the Laramide intrusive rocks. Many of the younger faults are mineralized and constitute the veins of the district.

The principal ore deposits are distributed irregularly around a central stock of sodic granite and related quartz monzonite porphyry. The deposits have a rough zonal arrangement (Lovering and Goddard, 1950, p. 260). Lead-silver and fluorspar deposits lie generally close to the stock, especially along its southwestern border. Pyritic gold deposits lie in a more distant medial zone, and the gold telluride

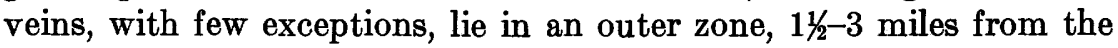
stock. Uranium deposits occur principally in the inner and outer zones.

Uranium-bearing fluorite veins (class 1 deposits of this report) occur throughout the inner zone, but not all fluorite veins contain uranium. Most of the known uranium occurrences are clustered along the west side of the stock, but some are south of the stock, and a few are east of it. Many of the uranium-bearing fluorite veins are alined in a zone that trends $\mathrm{N} .30^{\circ} \mathrm{W}$. along the western edge of the town of Jamestown (fig. 14).

The Fair Day mine, the principal example in the Jamestown district of a class 3 deposit, lies at the margin of the mineralized area, about $1 \frac{1}{2}$ miles west of the stock.

\section{BLUE JAY MITHE}

By R. U. KING

The Blue Jay mine, about half a mile southeast of Jamestown (fig. 14), contains radioactive fluorite veins from which uraninite, uranothorite, and coffinite have been identified. The output of fluorspar probably has amounted to a few thousand tons (Goddard, 1946 , p. 33). Output of uranium has been negligible. The mine workings consist of several short adits, a 300 -foot vertical shaft, and drifts at the 150- and 300-foot levels. Examinations of the 300 -foot level were made by E. P. Beroni, H. C. Granger, and R. U. King in 1949 and by V. R. Wilmarth and D. H. Johnson in 1950. The geology of the mine has been described by Goddard (1946, p. 33-34).

The Blue Jay vein strikes about N. $70^{\circ} \mathrm{W}$., is about vertical, and is at least 1,000 feet long. It is in altered granodiorite except at its eastern end, where it extends into Silver Plume Granite and pegmatite (Goddard, 1946, pl. 3). Through most of its length, the vein ranges in width from 6 inches to 7 feet, but at one place where two branches join, it is 16 feet wide. It consists principally of brecciated coarsely crystalline deep-purple fluorite, which is cemented by a fine-grained 
mixture of fluorite, quartz, ankerite, clay minerals, pyrite, galena, and sparse uraninite and uranothorite.

Uranium is scattered sparsely through most of the vein on the 300foot level. A sample of fluorspar from an ore shoot near the eastern end of the level contained 0.037 percent uranium, and one from the hanging wall of the vein 100 feet east of the shaft contained 0.045 percent. Other samples of dark-purple fluorite and fluorite breccia contained 0.018-0.084 percent uranium. A sample of altered granodiorite adjacent to the vein contained only 0.002 percent uranium.

The uraninite and uranorthorite are principally in the matrix of the fluorite breccia, where they form inclusions in the granulated (and in some part younger?) fluorite (George Phair and Kiyoko Onoda, written communication, 1950). They are associated with deep-purple fluorite, which is thought to owe its color to radiation. Phair and Shimamoto (1952, p. 664) concluded that the uranothorite and uraninite crystallized with the fluorite and were not introduced into it mechanically during brecciation. The precise mode of occurrence of coffinite, first identified in the uraniferous fluorspar by $\mathbf{E}$. J. Young (oral communication, 1959), is not known.

\section{FAIR DAY MINE}

The Fair Day mine, the most productive uranium mine in Boulder county, is about 2 miles west of Jamestown, on the south side of Overland Mountain. Shallow surface openings bordering the mine are at altitudes ranging from about 8,375 to 8,600 feet.

Uranium was first discovered in the Overland Mountain area in 1954, when autunite was noted in shallow pits on the Baltimore Belle claim about 2,300 feet north-northeast of the present Fair Day mine. Later the same year, autunite was found in pits on the same fracture zone about 1,000 feet northwest of the Baltimore Belle pits, and a few tons of rock containing the secondary uranium mineral were stockpiled. The first discovery in the Fair Day mine area was in 1955 when autunite and torbernite were found in northeastward-trending fractures in shallow pits on the Fair Day claim. Subsequently, in the fall and winter of 1956 , the fractures were explored by diamondcore drilling and a significant uranium ore body was intersected at shallow depth. In 1957 an inclined shaft was sunk and production of uranium ore began. In 1958 exploration was conducted with the assistance of a contract with the Defense Minerals Exploration Administration, and by 1959, the mine workings consisted of an inclined shaft approximately 120 feet long, drifts and crosscuts aggregating about 1,100 feet in length, and four stopes (pl. 2). Subsequent to our investigations an adit was driven at a depth of about $\mathbf{3 5 0}$ feet below 
the upper workings. This adit intersected uranium ore of good grade, which was being mined in 1960 (J. D. Schlottmann, oral communication, 1960).

The production from the mine for the years 1958 through 1960, as reported to the U.S. Bureau of Mines, is tabulated below:

Uranium production from the Fair Day mine, Boulder County

\begin{tabular}{|c|c|c|c|}
\hline & $\begin{array}{c}\text { Crude ore shipped } \\
\text { (short tons) }\end{array}$ & $\underset{\text { (percent } \mathrm{U}_{3} \mathrm{O}_{8} \text { ) }}{\text { Grade }}$ & $\begin{array}{c}\mathrm{U}_{3} \mathrm{O}_{8} \\
\text { (pounds) }\end{array}$ \\
\hline 1958 & $\begin{array}{r}2,246 \\
870 \\
4,131\end{array}$ & $\begin{array}{r}0.47 \\
.42 \\
.63\end{array}$ & $\begin{array}{r}21,249 \\
7,290 \\
52,181\end{array}$ \\
\hline Total _. & 17,247 & - & 80,720 \\
\hline
\end{tabular}

1 This ore has an estimated value of nearly $\$ 400,000$.

Although Overland Mountain consists largely of Silver Plume Granite, blocks and patches of metasedimentary gneiss make up about 50 percent of the rock exposed at the surface in the vicinity of the Fair Day mine. The gneiss is principally fine- to medium-grained graphitic biotite gneiss that contains variable amounts of garnet, sillimanite, and pyrite. It has a general northeast strike, dips steeply northwest, and is folded about axes that plunge steeply northwest. The folds are only a few feet across and are nearly isoclinal. The Silver Plume Granite in the mine area is mainly a medium-grained seriate biotite-muscovite granite. It is nearly massive but has a weak primary foliation that is subparallel to contacts. The foliation is conspicuous only adjacent to inclusions of the gneiss.

Two sets of faults are exposed in the Fair Day mine. One set trends northward and is the more persistent and conspicuous; the other set trends northeastward (pl. 2). Faults of the northwardtrending set are steep and display right-lateral displacements of as much as a few feet and slickensides and mullions that plunge about $20^{\circ} \mathrm{N}$. They are characterized by gouge- and breccia-filled fractures and argillized walls. Two main faults of this set are distinguished as faults "A" and "B." Fault "A", intersected in 101-A-, 101-B-, 104-, and 105-drifts, strikes north and dips $80^{\circ} \mathrm{E}$. to vertical. Fault " $\mathrm{B}$ " is more variable in strike and bends markedly between the 103and 104-A-drifts. To the south of 103-drift fault " $B$ " strikes N. $10^{\circ} \mathrm{E}$., is nearly vertical, and consists of two fractures separated by 2-4 feet of altered and sheared country rock; to the north of the drift the fault strikes $\mathrm{N} .20^{\circ} \mathrm{W}$. along 105-drift and is somewhat braided. Fault " $B$ " probably joins fault " $A$ " a short distance north of the mine workings. 
The northeastward-trending faults - the principal vein fissures in the mine - are less persistent and more irregular than the northwardtrending faults. Although most faults of this group strike N. $30^{\circ}-$ $45^{\circ} \mathrm{E}$., some strike north-northeast and others strike nearly east. With the exception of the fault in 101-B-drift, all the faults dip steeply northwest. Most of them terminate against one of the northwardtrending faults, and some curve into these faults at the junctions. Displacements on the northeastward-trending fractures are small; J. D. Schlottmann (oral communication, 1958) observed a left-lateral displacement of about 1 foot along the vein in 103-drift.

The black uranium-ore minerals pitchblende and coffinite occur principally in the northeastward-trending fissures, especially at and near junctions with the northward-trending faults. Lesser amounts occur in the northward-trending faults at these junctions. The veins range from simple and single-filled fractures to complex fracture zones as much as 10 feet wide made up of numerous subparallel filled fissures. Vuggy openings as much as a few inches in diameter are common. The vein minerals fill cracks and fissures and coat breccia fragments and the walls of vugs. Individual veinlets or coatings range from paper thin to half an inch in width. The yield of any particular ore body depends upon the spacing and abundance of the numerous tiny stringers and coatings.

The pitchblende and coffinite occur in a quartz gangue in company with pyrite and lesser amounts of iron-poor sphalerite, chalcopyrite, galena, and marcasite, which generally are not visible megascopically. Molybdenum salts form a conspicuous blue coating on some of the broken ore soon after exposure to air. Several other metals accompany the coffinite and pitchblende as shown in table 3.

$\mathrm{X}$-ray analysis and microscopic studies of the black uranium ores have indicated that the pitchblende and coffinite are finely intergrown. Megascopically the pitchblende is a bright, shiny material that yields a black powder, whereas the coffinite is a dull, black, granular-appearing material that yields a gray powder. Both minerals have a microcolloform structure. In polished sections, the coffinite may be distinguished from the pitchblende by a lower reflectivity, weak internal reflections, and, rarely, a radial-fibrous structure, as can be seen in figure 9. In thin sections, the coffinite is brown and slightly translucent; some of it is finely intergrown with clay minerals(?) and quartz as well as with sulfide minerals. The pyrite and quartz intergrown with the uranium minerals also have a conspicuous microscopic colloform structure. Pyrite may be in delicate concentric layers that differ slightly in color and reflectivity and quartz in layers that differ in color. 
Paragenetic studies indicate that quartz generally was the first mineral to be deposited. At a later stage, pitchblende and coffinite were deposited virtually contemporaneously, generally in company with quartz and pyrite, although some pyrite was deposited after the uranium minerals also. In some sections of the ores, pitchblende and coffinite are interlayered in distinct colloform bands a millimeter or less in thickness. In these sections the contact between the two phases is sharp but commonly irregular or ragged. Where the sequence of deposition can be determined, the coffinite is later than the pitchblende (fig. 9), and in a few sections, angular fragments of pitchblende occur in a groundmass of coffinite. The pitchblende in these sections appears to have been brecciated before the coffinite was deposited, producing a distinct "sea and island" texture. Most of the sphalerite, chalcopyrite, and ilsemanite(?) occur within coffinite. At places narrow sphalerite veinlets cut pitchblende.

Samples collected during the mapping suggest that coffinite is the dominant primary uranium mineral in the higher parts of the mine and decreases in relative abundance downward. A sample from 70 feet above the level in 103-stope consists of finely divided coffinite and clay minerals and contains traces of ilsemanite(?) but no pitchblende. A sample from 50 feet above the level in the same stope contains coffinite and pitchblende in separate colloform bands, and the coffinite contains abundant anhedral grains of pyrite and sphalerite. Two samples from the level show nearly equal amounts of coffinite and pitchblende, but in one, the two minerals are interbanded, and in the other, the pitchblende occurs as angular fragments in the coffinite. Both sphalerite and chalcopyrite occur in the coffinite.

Five ore bodies have been mined, and these are named from their position in the mine relative to drifts - the 101-, 103-, 104-, 104-A-, and the 104-B-ore bodies. About three-quarters of the yield has come from the 103- and the 104-ore bodies. The 103-ore body-the initial discovery-was mined to a vertical height of about 95 feet, and the 104-A-ore body was mined to a height of about 40 feet. These two ore bodies are known to extend to a distance of more than 150 feet below the level.

The ore bodies are localized in the northeastward-trending vein fissures at their junctions with the northward-trending faults (pl. 2). An exception is 104-ore body, which occurs in fault " $B$ " at its junction with the northeastward-trending vein mined in 104-A-drift and stope. In addition to vein junctions, lithology of the wallrock appears to have affected localization of ore. The graphitic biotite gneiss appears to be a particularly favorable rock, for it is by far the dominant wallrock of the productive fissures. Where the ore-bearing 
fissures pass from this gneiss into Silver Plume Granite, they become less distinct and barren. In general, the uranium ore seems to have been localized by the same factors as the gold telluride ore of the Buena mine about half a mile to the east (Lovering and Goddard, 1950 , p. 267).

The upper parts of the ore bodies at the Fair Day mine are oxidized to depths of at least 25 feet below the surface, but details of the mineralogic and chemical changes are not known. Bassetite was found in the upper part of the 103-ore body about 70 feet above the level, and autunite and torbernite occur at surface exposures of the ore bodies.

\section{FATIONS TREASURE MINE}

By R. U. KING

The Nations Treasure mine, one of the mines that contains radioactive fluorspar deposits, is on the west side of the sodic granite stock of Porphyry Mountain (fig. 14; see also Goddard, 1946, pl. 2; Lovering and Goddard, 1950, fig. 77, p. 261). The mine workings, at an altitude of 7,452 feet, consist of a few hundred feet of irregular underground workings (fig. 15) and a large glory hole.

The mine is in the southeastern part of a breccia zone about 400 feet wide and 1,200 feet long that strikes approximately $\mathrm{N} .55^{\circ} \mathrm{E}$.
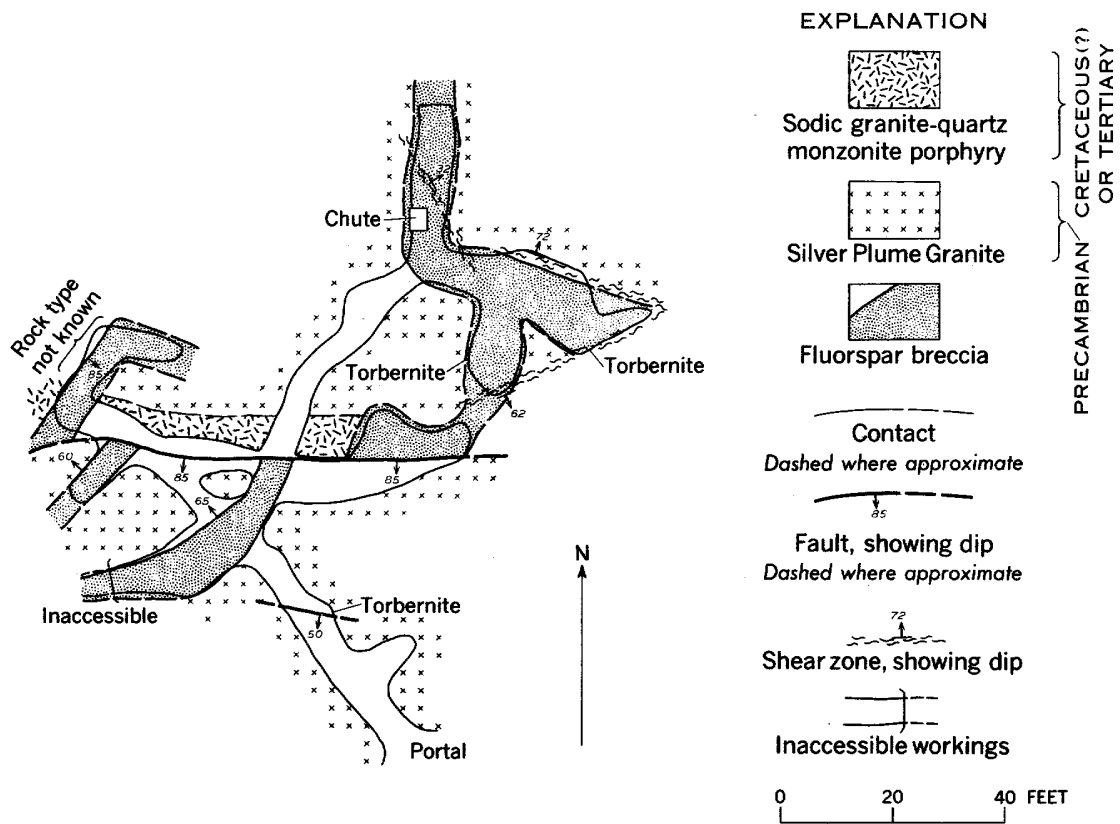

Figure 15.-Geologic map of the Nations Treasure mine, Jamestown district, Colo. Geology by V. R. Wilmarth and D. H. Johnson, 1950. 
and dips steeply (Goddard, 1946, p. 44). The breccia zone lies in Silver Plume Granite which is cut within the mine area by a dike of sodic granite that may be younger than the ore. Several small irregular fluorspar veins and breccia zones occur within the mine, and an irregular fluorspar breccia body in the northeastern part of the workings has been stoped to the surface, 20 feet above.

Torbernite is widespread in the breccia and also occurs as thin coatings on fractures in the adjoining wallrocks. In the breccia, torbernite occurs in the matrix material of fine-grained fluorite mixed with clay minerals and is accompanied by sparse pyrite, galena, limonite, chalcedony, and chlorite. Fragments of granite, coarsegrained fluorite, and quartz in the breccia are barren. The older coarsely crystalline fluorite is lighter colored than the younger finer grained fluorite and is corroded and replaced by the younger fluorite. Chalcedony fills abundant narrow fractures in the brecciated fluorite.

Analyses (by U.S. Geol. Survey) of samples taken from the mine are listed as follows:

\begin{tabular}{|c|c|c|c|}
\hline Sample & Desaription & $\begin{array}{l}\text { Equivalent } \\
\text { uraniumm } \\
\text { (percent) }\end{array}$ & $\begin{array}{l}\text { Uranium } \\
\text { (percent) }\end{array}$ \\
\hline$W-31-50 \ldots$ & Grab sample of galena, pyrite, and & 0.083 & 0.075 \\
\hline $32-50$ & $\begin{array}{l}\text { dark-purple fluorite. } \\
\text { 1-ft channel sample across dark-purple }\end{array}$ & 10 & \\
\hline $33-50 \ldots$ & $\begin{array}{l}\text { fluorite. } \\
\text { Grab sample of altered granite with }\end{array}$ & .13 & \\
\hline $34-50 \ldots \ldots$ & $\begin{array}{l}\text { some torbernite flakes. } \\
\text { 4-ft channel of purple fluorite }\end{array}$ & .035 & .024 \\
\hline
\end{tabular}

VICTORY GROUP

The Victory group includes several claims approximately half a mile east of Jamestown (fig. 14), on the lower part of the southwestern slope of Golden Age Hill. Two claims in the group, the Lulu B and Gold Leaf, were located in the early 1920's on pyritic gold veins, but only a small quantity of gold ore was shipped. Later, these claims were prospected for fluorite. The Victory claim was located for fluorspar in the late 1930's, and a few carloads were shipped.

Uranium was discovered on the Victory group of claims in 1955, and early in 1956 ore was being mined from an opencut about 60 feet long, 25 feet wide at the surface, and 5 feet wide at track level. About 600 tons of uranium ore containing about 0.16 percent $\mathrm{U}_{3} \mathrm{O}_{8}$ have been extracted from the claims, mainly from the Lulu B claim.

The country rock is Silver Plume Granite that contains blocks of biotite gneiss. The gneiss generally strikes northeastward and dips 
steeply northwestward, but in the opencut its contact with granite strikes east.

Torbernite, the only uranium mineral known in the mine, is concentrated along joints and other fractures and is disseminated in the gneiss and granite for distances of a few feet from their contact. The exposed part of the deposit is about 50 feet long in an east-west direction, as much as 20 feet wide and at least 20 feet high. The lower limit of the deposit is not exposed in the pit. Grab samples of ore-bearing material taken from the pit contained from 0.1 to 0.3 percent $\mathrm{U}_{3} \mathrm{O}_{8}$. One sample contained 0.22 percent equivalent $\mathrm{U}_{3} \mathrm{O}_{8}$ and 0.247 percent uranium.

\section{GOLD HILL DISTRICT}

GENERAL FEATURES

The Gold Hill district, about 3 miles south of Jamestown and 6 miles northwest of Boulder (fig. 2), has been the scene of mining operations since 1860 and has yielded ores worth between $\$ 12$ million and $\$ 14$ million (Lovering and Goddard, 1950, p. 236). Several of the veins in the district are known to be radioactive, but there has been no production of uranium ores. A systematic geologic study of the district was made from 1937 to 1939 by Goddard (Goddard, 1940; Lovering and Goddard, 1950, p. 234-255), and a reconnaissance for radioactivity was made in 1953 (Campbell, 1955).

The Gold Hill district is in the northern part of the Precambrian Boulder Creek batholith (Lovering and Goddard, 1950, pl. 2). At the north edge and in the western part of the district, biotite gneisses wrap around and interfinger with rocks of the batholith. Both the gneiss and the Boulder Creek Granite are cut by dikes and small irregular bodies of Silver Plume Granite, and all the Precambrian rocks are cut by scattered dikes of Laramide porphyries.

The outstanding structural features of the district are strong northwestward-trending breccia reefs. (See Lovering and Goddard, 1950, pl. 2.) The most persistent of these faults form a nearly vertical system that trends N. $25^{\circ}-50^{\circ} \mathrm{W}$. across the district. Faults of a less persistent system trend N. $60^{\circ}-85^{\circ} \mathrm{W}$., dip gently to steeply, and break across between faults of the more northerly trend. Other important faults that probably are related to the breccia reefs strike northwest and dip $20^{\circ}-50^{\circ} \mathrm{NE}$.

Most of the veins or fissures strike northeast and dip steeply. They are productive mainly near their intersections with breecia reefs. Gold is the chief metal mined in the district, although small amounts of silver are associated with the gold in most veins. Most of the veins are the gold-telluride type, but there are some economically important 
pyritic gold veins and a few important silver-lead veins. Galena and sphalerite are minor constituents of the gold-telluride veins. Variable amounts of chalcopyrite, pyrite, gray copper, sphalerite, and galena occur in the pyritic gold and the silver-lead veins. Quartz of several varieties is the chief gangue mineral.

Uranium is a minor constituent of several veins, but the relation of uranium to the more abundant ore minerals is poorly known because of alteration subsequent to its deposition. Pitchblende, generally as the sooty variety, has been recognized in a few veins, but more commonly uranium is in the form of colored secondary minerals, as torbernite, metatorbernite, and schroeckingerite. The veins are typical of class 2 deposits-those in which uranium minerals are subordinate to base-metal sulfide minerals. One of the deposits is described below, and several others have been described by Campbell (1955).

\section{BLACK CLOUD MINE}

The Black Cloud mine, about 1 mile east of Gold Hill, has been worked intermittently for a complex ore that contains gold, silver, lead, and zinc. Most of the output was made before 1910. In 1950, a radioactive sample was obtained from the mine and the accessible workings were mapped (fig. 16).

The principal vein in the Black Cloud mine strikes northeast and generally dips steeply northwest. Subsidiary branching veins strike more northerly, approximately parallel to pegmatite dikes and joints in the granite. In the west drift the vein is $2-3$ feet wide on the average and consists chiefly of fine-grained gray quartz in brecciated and iron-stained wallrock. Pyrite is finely disseminated in the quartz. In places, substantial quantities of galena, sphalerite, gold, and silver occur in the vein. Such ore is localized mainly near junctions of the Black Cloud vein with subsidiary branch veins.

A black claylike radioactive material, probably sooty pitchblende, occurs as fracture fillings in the Black Cloud vein for a distance of 200 feet along the west drift on the third level. Locally the radioactive material occurs over the width of the vein, but more commonly it is confined to a 6- to 12-inch zone within the vein or along one of its walls. Uranium content of 11 channel samples ranged from 0.001 to 0.081 percent. In 10 of the samples the radioactivity (equivalent uranium) was 2-12 times greater than the uranium content. This disequilibrium is interpreted to be the result of leaching of uranium. 


\section{EXPLANATION}

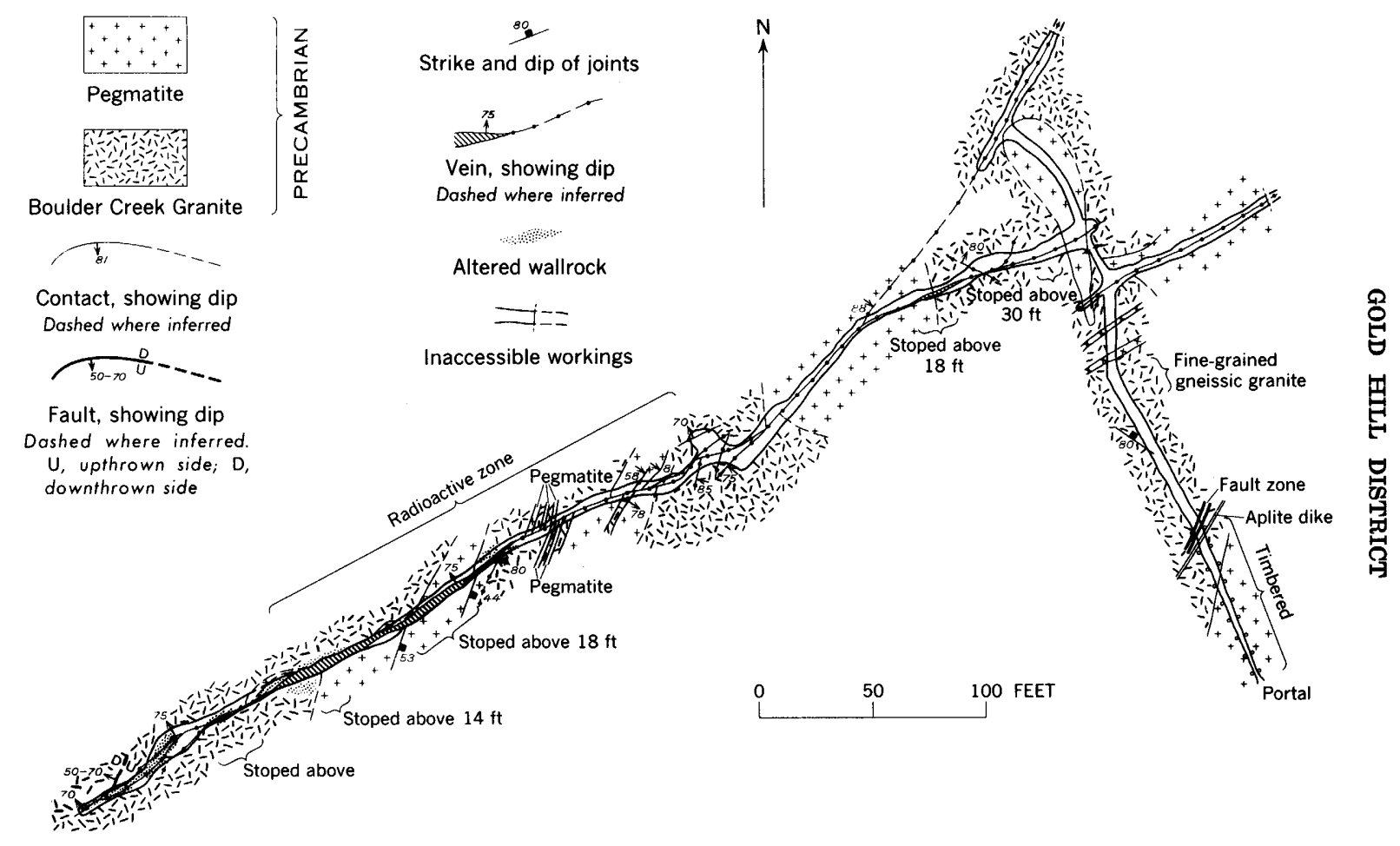

Figurn 16.-Geologic map of part of the third level, Black Cloud mine, Boulder County, Colo. Geology by F. B. Moore, E. N. Hinrichs, and D. M. Sheridan, August 1950. 


\section{OTHER ARFAS}

CARIBOU MTHE

The Caribou mine is about 5 miles west of Nederland, Colo., at an altitude of about 10,000 feet (fig. 2). The mine has been a substantial source of lead and silver and also has yielded a small amount of uranium ore (Moore and others, 1957). Pitchblende was first noted at the mine in 1948, when the 1040-level was reopened by Consolidated Caribou Silver Mines, Inc. The mine workings consist of a 3,645-foot adit-the Idaho tunnel (500-level) - which connects with the 1,100-foot inclined Caribou shaft and about 7,000 feet of drifts on 14 levels, 9 of which are below the Idaho tunnel. The geology of the mine has been described in detail by Moore, Cavender, and Kaiser (1957) and by Wright (1954), and only a summary is presented here.

The country rock in the Caribou mine area is biotite gneiss of Precambrian age, which is cut by the Caribou stock of Laramide age. The stock is a composite intrusive mass composed chiefly of monzonite-the chief wallrock at the mine-accompanied by smaller bodies of titaniferous magnetite and ultramafic and gabbroic rocks. The vein fissures are of several trends, in a complex and poorly understood fault pattern. A vein known as the Radium vein (see Moore and others, 1957, p. 537) is of principal interest here.

The pitchblende of the mine occurs in the Radium vein at depths between 900 and 1,140 feet and in minor quantity in an unnamed vein on the 500-level. Pitchblende is known in two ore shoots on the Radium vein. The larger shoot extends from the 920-level downward to the 1140-level and has a stope length of more than 70 feet. A smaller ore shoot extends for 35 feet along the drift on the 1040level and to a height of $\mathbf{7 0}$ feet above the level. Both shoots appear to plunge steeply to the west. Pitchblende is distributed erratically within the ore shoots, and analyses of grab samples vary greatly. Most of the pitchblende forms an irregular layer less than an inch to 6 inches thick between sulfide ore and gouge along the footwall of the Radium vein. The pitchblende is associated with galena, sphalerite, and silver minerals, and elsewhere the Radium vein contains minor pyrite, chalcopyrite, and gersdorffite. Pitchblende was deposited early in the second stage of vein mineralization recognized by Wright (1954, p. 161-162).

Wright (1954, p. 154-156) distinguished two varieties of pitchblende, a hard dense black form with a pitchy luster and a soft dull black fine-grained porous sooty form. The hard lustrous pitchblende has a colloform texture with characteristic radial and concentric cracks, both of which are filled in places by pyrite. The soft, sooty variety of pitchblende fills fractures and coats vugs in the hard variety and in sulfide ore. At places it appears to grade into the 
hard variety. Both varieties of pitchblende were identified by Wright (1954, p. 152) as uraninite.

\section{SHIRIEY MINE}

The Shirley mine, in the NW/1/4 sec. 19, T. 1 S., R. 73 W., about 6 miles west of Nederland, is in a monzonite stock of Tertiary age near its contact with biotite gneisses. The mine workings consist of a 620-foot adit, 3 raises, and 10 small stopes (pl. 3).

The vein exposed in the mine strikes about N. $30^{\circ}$ E., dips $50^{\circ}$ SE., and is 6 inches to 3 feet wide. It consists of subparallel veinlets of gray or black cryptocrystalline quartz, generally an inch or less thick but locally as much as a foot thick, and thin veinlets of pyrite, in silicified iron-stained wallrock. Altered monzonite bordering the vein consists of an inner silicified zone, 3 inches to 2 feet thick, and an outer argillized zone, 6 inches to 5 feet thick. The argillic zone is yellow green and friable.

Only the principal radioactive segment of the vein is labeled on plate 3 , but the vein is radioactive in segments $2-12$ feet long in at least seven other places. The radioactive material is black and sooty and coats quartz vugs, most of which are on the hanging-wall side of the vein.

Samples of the radioactive material contain from 0.001 to 0.034 percent uranium and from 0.009 to 0.072 percent equivalent uranium. The radioactivity of individual samples is as much as 10 times greater than the uranium content. This disequilibrium was determined by J. N. Rosholt, Jr., of the U.S. Geological Survey, to result from excess daughter products of uranium.

A sample of radioactive material from the dump of the X-Ray mine, 149 feet above the adit of the Shirley mine, contained 0.001 percent uranium and 0.014 percent equivalent uranium.

SISK MINE

By F. B. Moore

The Sisk mine is 3 miles northwest of Lyons (fig. 2) and $1 / 4$ mile north of State Highway 66, at an altitude of about 6,500 feet. Traces of uranium at the surface led to drilling of several exploratory holes in 1956. The drill holes intersected small stringers of radioactive material, and in April 1957, an inclined shaft was started and sunk to a depth of 40 feet. Drifts were driven in two directions along the trend of a fracture zone (fig. 17), and a few tons of uranium ore were obtained.

The country rocks in the mine area are biotite gneisses and schists and a pink granite that has been called Silver Plume Granite by Boos 


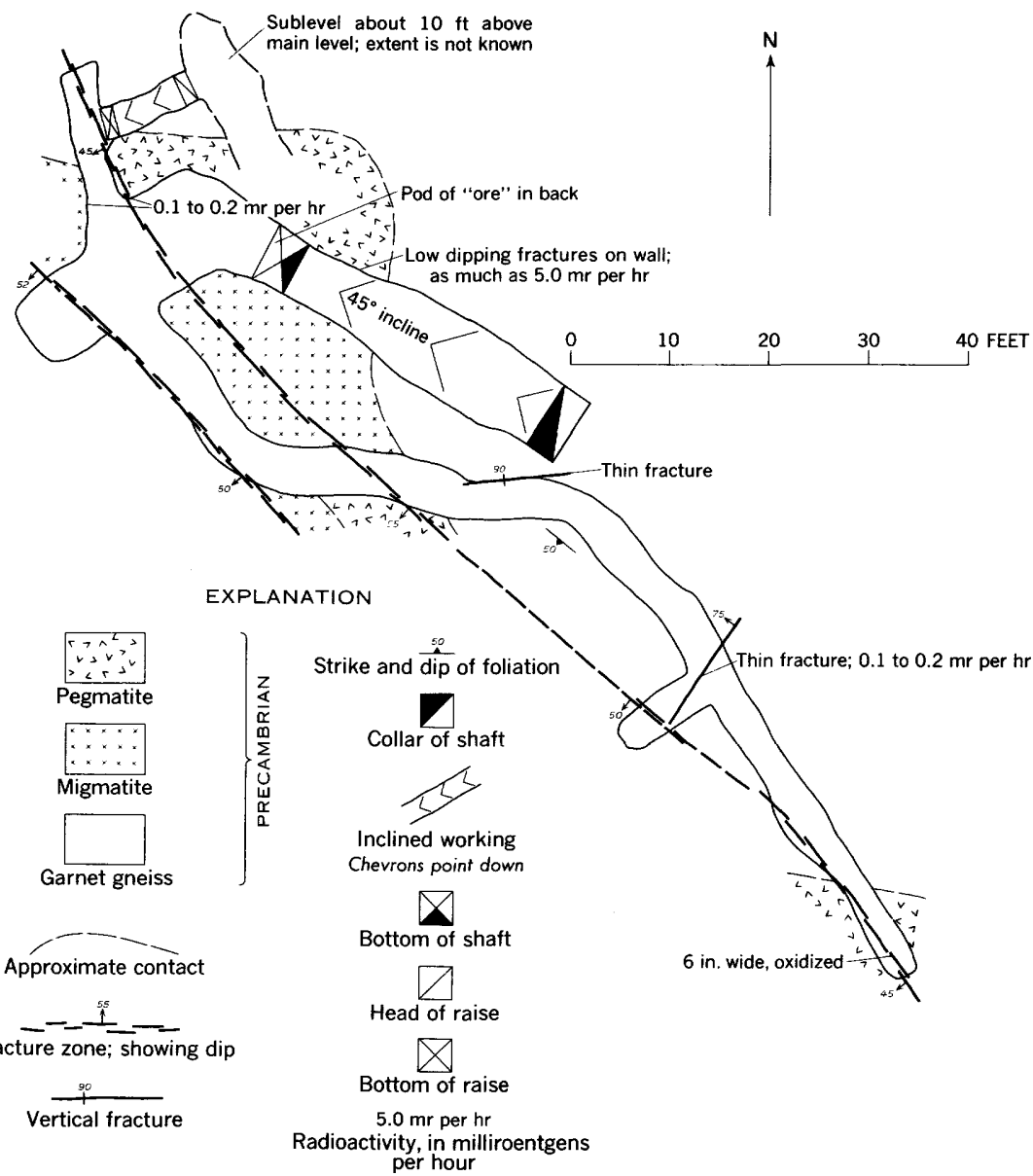

Figure 17.-Geologic map of the underground workings, Sisk property, Boulder County, Colo. Geology by F. B. Moore, 1958. Base map furnished by company; published by permission.

and Boos (1957). The gneiss, dominantly a garnetiferous biotitequartz gneiss, strikes northwest and dips $50^{\circ}-60^{\circ} \mathrm{SW}$. The granite is pegmatitic and locally forms migmatite where it is intimately interleaved with the gneiss. It cuts across the structure of the gneiss.

The mine workings are on two fracture zones, which are mainly parallel to the foliation of the gneiss. These zones are about 10 feet apart and consist of 6 inches to a foot of crushed rock and about an inch of iron-stained gouge. Pitchblende forms thin colloform coatings in places along the footwall of the eastern fracture zone and in small subsidiary fractures that crosscut the foliation of the country rock. 


\section{CLEAR CREEK COUNTY}

Although numerous uranium-bearing veins are known in Clear Creek County, none of them has proved economically significant, and production has been negligible. Pitchblende was identified in the Jo Reynolds mine, 6 miles west of Idaho Springs, as early as 1886, and in 1919 , this mine produced 8 tons of uranium ore that assayed 72 percent $\mathrm{U}_{3} \mathrm{O}_{8}$ (Harrison and Leonard, 1952). More recently, a little more than a ton of low-grade uranium ore was shipped from the Martha E tunnel, 3 miles southwest of Idaho Springs (Harrison and Wells, 1959, p. 72). In 1947, the U.S. Geological Survey, on behalf of the Atomic Energy Commission, started a reconnaissance of the mining districts of the county and later made detailed investigations in several of them. These studies resulted in the discovery of many radioactive localities (Wells and Harrison, 1954) but did not disclose any large uranium ore bodies. Most of the uranium ore occurs as a local and minor component of the gold- and silver-bearing base metal sulfide veins of the county.

\section{IDAHO SPRINGG AND ADJACENT DISTRICTS}

GENERAI FEATURES

The Idaho Springs and nearby Lawson-Dumont-Fall River, Freeland-Lamartine, and Chicago Creek mining districts (fig. 18) have made an output of more than $\$ 50$ million in gold, silver, lead, zinc, and copper. The geology of the region has been studied by Spurr, Garrey, and Ball (1908), by Bastin and Hill (1917), and more recently by Harrison and Wells $(1956 ; 1959)$. A recent summary of the economic geology, with especial emphasis on the uranium deposits, is contained in a report by Sims and others (1963).

The mining districts of the area are in metasedimentary rocks that are intruded by small bodies of Precambrian igneous rocks and numerous dikes and small plutons of Laramide porphyries. The Precambrian rocks are cut by many faults; most of which trend northeastward.

The ore deposits are fissure fillings in the faults and are distributed around a center of mineralization near Idaho Springs. Pyrite-quartz veins that contain chalcopyrite and tennantite occur. in an inner zone and are chiefly valuable for gold. Silver-bearing galena-sphalerite veins occur in an outer zone that extends as much as 3 miles from the center of mineralization. A few gold telluride veins are found south of Idaho Springs.

The uranium deposits are of class 2 as defined in this report. Uranium is present in small quantities in both the pyritic and the galenasphalerite veins. Pitchblende (uraninite) has been identified in a few veins, but in most veins the uranium is in the form of secondary min- 

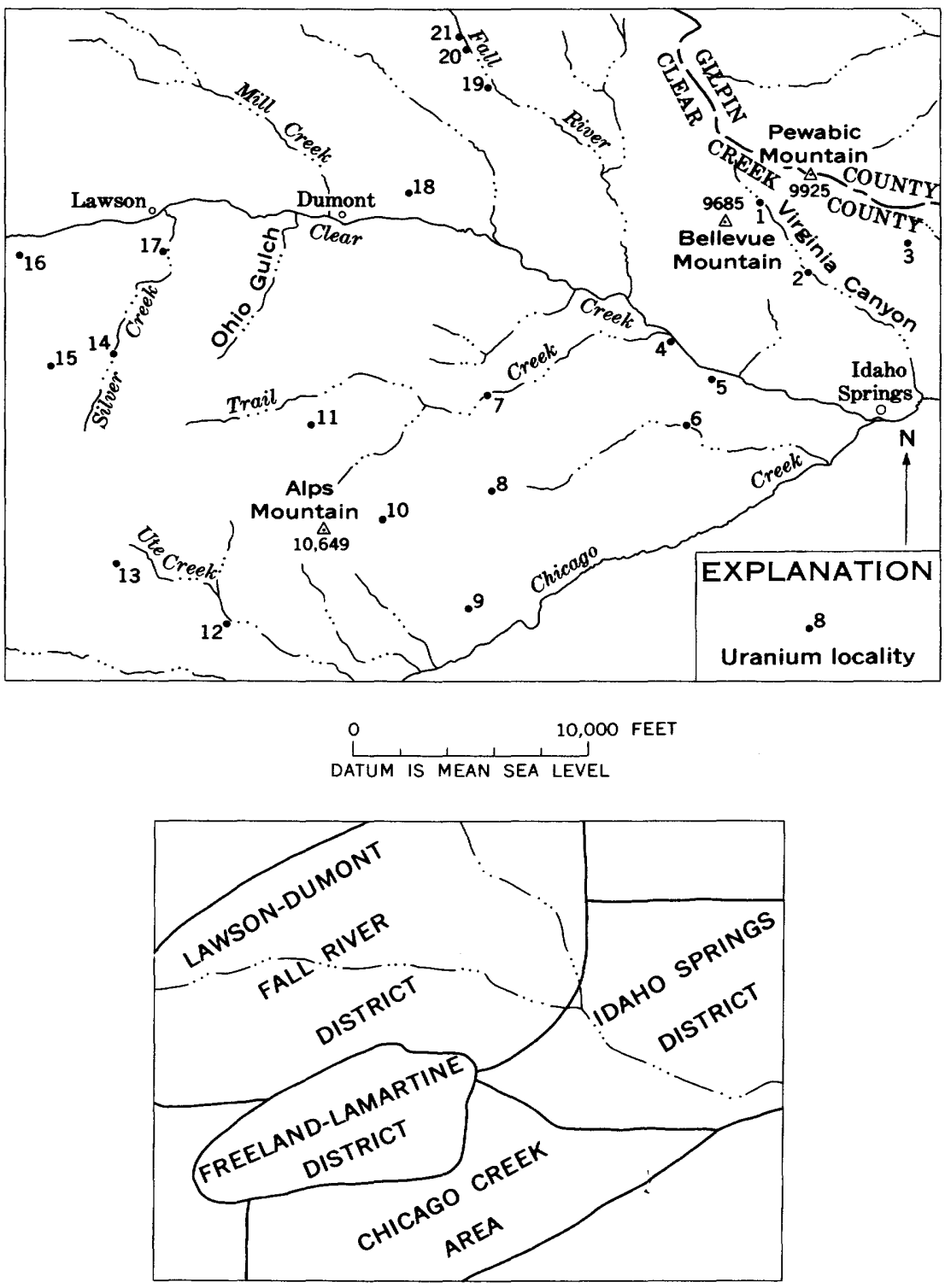

0

2

4 MILES

FIGURE 18.-Map of the Idaho Springs and adjacent districts, Clear Creek County, showing principal uranium occurrences. List of mines: 1. Diamond Joe tunnel, 2. Red Jacket, 3. Gem, 4. Alma Lincoln, 5. Stanley, 6. Star, 7. Sunnyside tunnel, 8. Martha $\mathrm{E}$ tunnel, 9. Orinoco tunnel, 10. Diamond Mountain tunnel, 11. Lamartine tunnel, 12. Humboldt, lower tunnel, 13. Baltic tunnel, 14. Nabob, 15. Robineau, 16. Bellevue-Hudson tunnel, 17. Jo Reynolds tunnel, 18. Golden Calf tunnel, 19. Mary tunnel, 20. Golconda tunnel, 21. Almaden tunnel. 
erals, especially torbernite and autunite. A small amount of material tentatively identified as uraniferous hydrocarbon was found in the Alma Lincoln mine, a mile west of Idaho Springs, and traces of coffinite have been recognized in the nearby Stanley mine (Sims and others, 1961). Because primary minerals have rarely been observed, little is known of character and distribution of the original uranium deposits.

Eighty-one abnormally radioactive localities are known in Clear Creek County, but only 21 contain material that has greater than 0.10 percent equivalent uranium. The locations of these 21 deposits are shown in figure 18. A group of deposits in the Fall River area, including the Almaden, Golconda, and Mary mines, is localized in garnetiferous calc-silicate gneiss and is of special interest because nickel and minor cobalt are associated with the uranium. One mine in this group is described briefly below.

\section{ALMADEN MINE}

The Almaden mine, on the southwest side of Fall River about $2 \frac{1}{2}$ miles above its junction with Clear Creek, consists of two principal drift adits and a shaft. The workings are on the Blazing Star vein, a galena-sphalerite type vein that contains local enrichments in silver.

The mine workings are in folded biotite gneisses that contain relatively thin layers of granite gneiss, pegmatite, amphibolite, and garnetiferous calc-silicate gneiss. All the known uranium occurrences are between walls of garnetiferous calc-silicate gneiss.

The Blazing Star vein strikes about N. $80^{\circ} \mathrm{W}$. and dips about $60^{\circ} \mathrm{NE}$. The vein is typically 2 inches to 2 feet wide and contains galena, sphalerite, chalcopyrite, tennantite, ruby silver, pitchblende, niccolite, and pyrite as primary minerals in a quartz-carbonatebarite gangue. Secondary minerals include native silver, proustite, pearceite, cerargyrite, and chalcopyrite.

Pitchblende occurs in small quantities in four widely separated places along the Blazing Star vein. In each of the occurrences, thin stringers of pitchblende, partly of the sooty variety, are exposed for distances of a few feet or a few tens of feet along the vein. The stringers are generally along one of the walls of the vein and are separated from the main sulfide ore streak by gangue or gouge. Small quantities of niccolite, pararammelsbergite(?), chalcopyrite, and freibergite are associated with the pitchblende.

\section{OTHER AREAS}

Only a few uranium deposits are known in Clear Creek County outside the Idaho Springs and adjoining districts. Best known of these is the deposit at the Gold Anchor mine, described below. Other deposits-of little economic significance-are known at the Bonus 
mine (sec. 27, T. 3 S., R. 74 W.), Keiper mine (sec. 26, T. 5 S., R. 75 W.), and Urad mine (sec. 31, T. 3 S., R. 75 W.).

\section{GOLD ANCHOR MUNR}

The Gold Anchor mine is in the Alice mining district, in the northcentral part of Clear Creek County (fig. 2), at an altitude of approximately 10,450 feet. The mine workings consist of a shaft about 190 feet deep, a tunnel level which connects with the shaft 50 feet below the collar, and two short levels at depths of 96 and 140 feet vertically below the tunnel level (pl. 4). The mine has been worked intermittently since the early 1880's but production has been small. Sulfide ores shipped prior to 1905 contained an average of more than $2 \mathrm{oz}$ of gold per ton, as well as $2 \mathrm{oz}$ of silver and 1.4-2.9 percent copper. In 1953, radioactive material was found on the dump of the shaft and in the tunnel level by the mine owner. The mine was then reopened, but so far as known, no uranium ore was shipped.

The Gold Anchor mine is on the west edge of a body of granodiorite, which is part of a moderately large pluton of Boulder Creek Granite that crops out in the vicinity of Alice. In the western part of the mine workings, biotite gneiss is exposed. The gneiss is locally cut by small bodies of pegmatite probably genetically related to the intrusive granodiorite. Both the gneiss and the granodiorite strike northeastward and dip moderately southeastward. Lineations (mineral alinement) plunge gently north-northeastward.

Two northeast-striking veins, here called the North and South veins, are exposed in the mine workings (pl. 4). The veins dip steeply toward each other and intersect 43 feet below the tunnel level. Both veins consist dominantly of quartz and pyrite but locally contain tennantite, chalcopyrite, and pitchblende, as well as gold, which is invisible.

Pitchblende has been identified in three places in the mine. On the first level (pl. 4), veinlets of pitchblende are exposed sporadically over an area of 8 by 10 feet in a hanging-wall segment of the vein just northeast of the shaft. On the tunnel level, pitchblende occurs in small quantity along part of the North vein and on the second level, it has been found in small quantity about 15 feet northeast of the face shown on plate 4 (Thomas Murphy, oral communication, 1957). In addition, samples collected systematically throughout the mine indicate a uranium content of $0.002-0.010$ percent in several places (pl. 4).

The pitchblende is later paragenetically than the pyrite in the samples studied. Its paragenetic relation to chalcopyrite and tennantite is not known. 


\section{GILPIN COUNTY}

Small quantities of high-grade uranium ore have been produced intermittently from Gilpin County since 1871. The production has come entirely from the Central City district, and most of it was made before 1920. World War II gave new impetus to the search for uranium ore. After the war several deposits were found at Central City and at other areas within the county, but these are small and at most have yielded only a few tons of ore. The total know uranium production from Gilpin County from 1871 to 1960 is about 427 tons of ore that contained 112,070 pounds of $\mathrm{U}_{3} \mathrm{O}_{8}$ (table 1 ).

All the known uranium deposits in Gilpin County are of class 2; that is those in which uranium minerals are subordinate to basemetal sulfides. The uranium occurs locally in the gold- and silverbearing base-metal veins, either as primary pitchblende (uraninite) or as one of several secondary minerals. Although some pockets of uranium ore are high grade, the uranium ore bodies are small and commonly are widely spaced; accordingly, they cannot be mined except in conjunction with other metals.

\section{CENTRAL CTTY DISTRICT}

GENERAI GEOLOGY

The Central City district is in southern Gilpin County, in the central part of the Front Range mineral belt. The district ranks first in metal production among the mining districts in the Front Range mineral belt, having a total output valued at about $\$ 100$ million. Gold accounts for about 85 percent of the dollar value of the ores, silver for nearly 10 percent, and lead, zinc, copper, and uranium for the remainder. The value of the uranium ore that has been produced is not known. The economic geology of the district has been described by Sims, Drake, and Tooker (1963) and Sims and others (1963).

Fifty-nine abnormally radioactive localities were known in the district in 1955; of these, about half have yielded selected samples containing 0.10 percent uranium or better. Eighteen of the principal deposits are shown in figure 19. Of these, uranium ore is known to have been shipped from seven: Kirk, Wood, German, and East Calhoun mines on Quartz Hill; the Carroll and Two Sisters mines on Nigger Hill; and the Bonanza on Justice Hill. The Blackhawk Lode No. 2 claim on Silver Hill was the source of a few tons of ore that was never shipped.

The Central City district lies in a Precambrian terrane that consists dominantly of metasedimentary gneisses. Microcline gneiss, the principal rock unit, forms a layer approximately 3,000 feet thick exposed along the axis of a gently arched anticline and is overlain on 


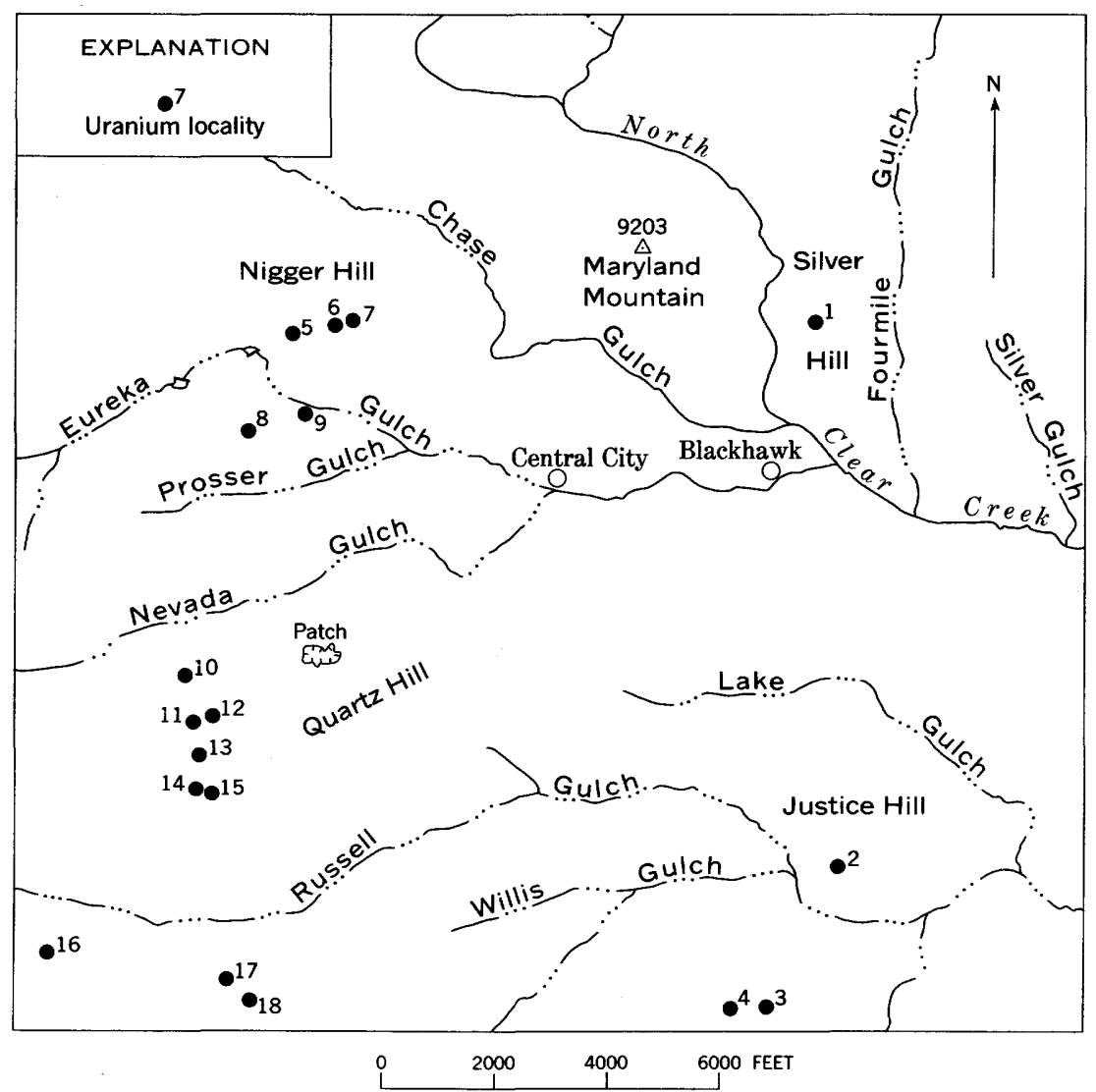

FIGURe 19.-Map of the Central City district, Gilpin County, showing principal uranium deposits. List of mines: 1. Blackhawk Lode no. 2; 2. Bonanza; 3. Cherokee; 4. Little Annie; 5. Carroll; 6. Two Sisters 7. R. H. D.; 8. J. P. Whitney; 9. Rara Avis tunnel; 10. Flack; 11. German; 12. Belcher; 13. Kirk; 14. Wood; 15. East Calhoun; 16. Springdale; 17. Old Town; 18. Iron.

the flanks of the anticline by a layer of migmatized biotite gneiss of approximately equal thickness. The gneisses are intruded by small bodies of granodiorite, presumably equivalent to the Boulder Creek Granite, and by Silver Plume Granite. All these Precambrian rocks are cut be small irregular plutons and dikes of porphyritic igneous rocks of Laramide age which range in composition from granodiorite to bostonite (Phair, 1952; Wells, 1960). The porphyries are among the most radioactive igneous rocks in the world (Larsen and Phair, 1954); quartz bostonite, the youngest rock of the igneous sequence, is 15-25 times as radioactive as the average granitic rock.

The district contains many closely spaced faults in a complex network. Relatively old fractures including breccia reefs and northnortheastward-trending faults are intersected by three sets of faults trending northeastward, east-northeastward, and eastward. Each of 
the fault sets is mineralized, but most of the veins and productive ore deposits are in the younger northeastward- and eastward-trending faults.

The veins occur dominantly as fillings in the faults. They contain pyrite, sphalerite, galena, chalcopyrite, tennantite and minor amounts of enargite, pitchblende, and gold tellurides in a quartz gangue, or less commonly, in a gangue of carbonate minerals, fluorite, and barite. Aside from the gold tellurides, gold and silver are principally associated with the sulfides, especially with chalcopyrite, tennantite, and enargite.

The veins are of two main types, one characterized by dominant pyrite and the other by dominant galena and sphalerite. Gold telluride veins are uncommon, in contrast to many districts in the northeastern part of the mineral belt. The distribution of the two main kinds of veins outlines a regional zonal arrangement of the ores around a major center of mineralization that extends from the Central City district southwestward into the Idaho Springs district of Clear Creek County. Pyritic veins characterize the core area which is approximately a mile in diameter. Galena-sphalerite veins characterize a peripheral zone, and in an intermediate zone about half a mile wide are transitional veins characterized by pyrite, galena, and copper minerals.

Uranium is a local constituent of veins of both principal mineralogic classes but is more abundant in veins in the intermediate and peripheral zones. It appears to occur in clusters of deposits throughout the district and not to be limited by the zonal pattern. The principal cluster of deposits occupies an area of about a square mile on Quartz Hill; others are in the Eureka Gulch, Silver Hill, and Willis Gulch areas (fig. 19).

At Central City, uranium was deposited before the base-metal sulfides, apparently during a distinct early stage of mineralization (Sims, 1956a, p. 745-747). The uranium appears to have been derived from several local and shallow sources, in contrast to the more pervasive sulfide mineralization, which appears to have stemmed from a moderately deep magmatic source beneath the central zone.

Two uranium deposits typical of the district-at the Carroll and Kirk mines-are discussed below. The Carroll mine is representative of the deposits associated with galena-sphalerite ores, and the Kirk mine is representative of the uranium deposits in gold-bearing pyritequartz veins. These deposits, as well as the others known in the district, are discussed more fully in the report by Sims and others (1963).

\section{CARROLI MINE}

The Carroll mine, in the Eureka Gulch area a mile west of Central City (fig. 19), has yielded 28.5 tons of crude uranium ore and con- 
centrates that contained 349 pounds of $\mathrm{U}_{3} \mathrm{O}_{8}$. The uranium ore was mined in conjunction with base-metal sulfide ores; 63 tons of crude ore and 107 tons of concentrates that were shipped during 1954 and 1955 contained 55 ounces of gold, 1,714 ounces of silver, 844 pounds of copper, 52,905 pounds of lead, and 56,767 pounds of zinc. The mine workings consist of a shaft inclined $65^{\circ} \mathrm{NE}$. and short levels at vertical depths of 102, 177, 228, and 278 feet (Sims and others, 1963, fig. 23).

The mine workings are in microcline gneiss that contains many thin layers of biotite gneiss, migmatite, and pegmatite. These rocks strike northeast and, except locally, dip moderately northwest.

The Carroll vein strikes about N. $70^{\circ} \mathrm{W}$. and dips $65^{\circ} \mathrm{NE}$.; it is 2-4 feet wide in most places but locally is as much as 9 feet wide. The uranium ore, as well as sulfide ore, occurs in a zone of ore shoots that has a breadth of about 60 feet and a known plunge length of more than 300 feet. (See Sims, 1956a, p. 752, and Sims and others, 1963.) The zone of ore shoots is localized at the junction of an eastward-trending vein with the Carroll vein and plunges about $\mathrm{N}$. $35^{\circ} \mathrm{W}$., which is also the approximate plunge of the intersection of the Carroll vein with the lithologic layering of the wallrocks. Pitchblende, the primary uranium ore mineral, occurs in three or more separate ore shoots that are arranged en echelon within the zone of ore shoots. The largest shoot has a vertical height of about 50 feet, a stope length of as much as 50 feet, and an average thickness of about 6 inches. Within the shoots, the pitchblende forms stringers or pods up to a few inches wide which commonly border one of the vein walls. Locally pitchblende is intercalated with sulfide minerals, and in such places is cut by sulfide stringers. The vein material between the ore shoots is nearly devoid of uranium.

The Carroll vein nicely illustrates the effects of supergene solutions on pitchblende. At a vertical depth of about 125 feet the hard primary pitchblende gives way upward to a soft sooty form. At a depth of about 105 feet, the sooty pitchblende in turn gives way to colored secondary minerals-especially torbernite and kasolite. Above a depth of about 50 feet, leaching prevailed, and the uranium has been removed from the vein. In the zone characterized by the colored secondary minerals, the uranium was dispersed, and the vein is lower in tenor than in the primary zone.

\section{KIRK MUNE}

The Kirk mine, on Quartz Hill about a mile southwest of Central City, has been one of the two main sources of pitchblende in the district. It has a recorded output of about 170 tons of uranium ore that contained $22,490 \mathrm{lb}$ of $\mathrm{U}_{3} \mathrm{O}_{8}$, but the total is probably larger. The ore is notable for its high grade, and some of it assayed $60-80$ 
percent $\mathrm{U}_{3} \mathrm{O}_{8}$ (Moore and Kithil, 1913, p. 44). In addition to uranium, the mine has yielded a moderate amount of gold, silver, and copper, and a few hundred pounds of lead and zinc. The mine workings consist of three shafts and six short levels turned from the main shaft at vertical depths of $88,141,203,239,301$, and 381 feet (Sims and others, 1963, pl. 6).

Microcline gneiss, the dominant rock of Quartz Hill, is the principal wallrock of the mine. The principal vein, the Kirk, strikes N. $70^{\circ}-$ $75^{\circ} \mathrm{E}$., dips about $75^{\circ} \mathrm{SE}$., and cuts the gneissic structure of the wallrock at a large angle. It is $1-5$ feet wide and contains a filling of quartz, pyrite, chalcopyrite, tennantite, and minor galena, sphalerite, and pitchblende. In contrast to the Carroll vein and others of the galena-sphalerite type, colored secondary uranium minerals are absent.

The pitchblende forms relatively small high-grade bodies that are dispersed sporadically along the vein. Most of it occurs in thin lenses and stringers or in bulbous kidney-shaped bodies as much as a foot across. The stringers and kidneys generally lie adjacent to the country rock on the hanging wall, and only rarely are they closely associated with the precious metal-bearing sulfide ore. The pitchblende has a colloform texture, and some botryoids are large enough to be seen with the naked eye.

\section{NORTH GIEPIN COUNTY DISTRICT}

The North Gilpin County district comprises several small mining camps in the vicinity of Apex (fig. 2) (Bastin and Hill, 1917, p. 190207; Lovering and Goddard, 1950, p. 193-196). Although the area has yielded no uranium ore so far as known, it contains several minor radioactive deposits, which were found during a systematic reconnaissance of about a hundred localities in 1952 (R. H. Campbell and Max Schafer, written communication, 1953). Localities that have material containing 0.01 percent equivalent uranium or greater are tabulated as follows:

Uranium content of selected samples from radioactive localities in North Gilpin County district

[S. P. Furman and J. N. Rosholt, Jr., analysts]

\begin{tabular}{|c|c|c|c|c|c|c|}
\hline \multirow{2}{*}{ Mine } & \multicolumn{3}{|c|}{ Location } & \multirow{2}{*}{$\begin{array}{c}\text { Classification } \\
\text { of deposit }\end{array}$} & \multirow{2}{*}{$\begin{array}{l}\text { Equivalent } \\
\text { uranium } \\
\text { (percent) }\end{array}$} & \multirow{2}{*}{$\begin{array}{l}\text { Uranium } \\
\text { (percent) }\end{array}$} \\
\hline & Sec. & T. (S.) & R. (W). & & & \\
\hline $\begin{array}{l}\text { Big Bertha } \\
\text { Elliot } \\
\text { Unknown 1. } \\
\text { Unknown 2 } \\
\text { Gold Chief. }\end{array}$ & $\begin{array}{r}29 \\
29 \\
26 \\
6 \\
27\end{array}$ & $\begin{array}{l}2 \\
2 \\
2 \\
2 \\
2\end{array}$ & $\begin{array}{l}73 \\
73 \\
73 \\
74 \\
73\end{array}$ & $\begin{array}{l}2 \\
2 \\
2 \\
3(?) \\
2\end{array}$ & $\begin{array}{c}0.017 \\
>10.0 \\
.37 \\
.05\end{array}$ & $\begin{array}{r}0.009 \\
>10.0 \\
>021 \\
>2.0 \\
.001\end{array}$ \\
\hline
\end{tabular}


The Elliot mine (Wealthy Lode claim) is on a narrow vein that contains minor amounts of pyrite, chalcopyrite, galena, and quartz. Pitchblende was noted at one place where the fissure transects granite pegmatite.

The radioactive material at Unknown mine 1 was found on the dump at the collar of a caved shaft. A grab sample showed a large excess of radioactivity over uranium: $2.4 \times 10^{-7}$ percent radium, $2.3 \times 10^{-9}$ curies per gram sample of radon, and $2.4 \times 10^{-9}$ curies per gram sample of $\mathrm{RaD}$. These data indicate that the disintegration products are virtually in equilibrium with the radium, but that there is excess radium. Computations based on the radium content of the sample indicate an original or preleaching grade of 0.07 percent uranium, if the disequilibrium of the $\mathrm{Ra} / \mathrm{U}$ ratio is attributed solely to differential leaching of uranium. Differential leaching of primary material, presumably pitchblende, on the dump since extraction of the ore probably accounts for the disequilibrium.

The deposit at Unknown mine 2 is about $2 \frac{1}{2}$ miles northwest of Apex (fig. 2) on the east side of the Apex road. According to J. D. Schlottmann, three veins at the prospect strike N. $60^{\circ}-70^{\circ} \mathrm{W}$. and dip $50^{\circ}-85^{\circ} \mathrm{N}$.; they cut Precambrian quartz-biotite gneiss that strikes N. $45^{\circ} \mathrm{W}$. and dips $30^{\circ}-35^{\circ} \mathrm{NE}$. Pitchblende coats fractures and is associated with minor amounts of quartz and pyrite. Galena was also observed on the dump but not with pitchblende.

OTHER AREAS

Small radioactive anomalies have been detected along breccia reefs and related faults in scattered localities in the eastern part of Gilpin County. At the Golder-Passarale property, in sec. 23, T. 2 S., R. $72 \mathrm{~W}$., torbernite is dispersed along fractures in brecciated country rock along the Junction Ranch fault. A shaft was sunk to a depth of 15 feet but did not disclose significant amounts of uranium ore. At the Jelly Roll claim, sec. 17, T. 3 S., R. 72 W., small quantities of uranium-bearing material occur in fractures within the Blackhawk fault.

\section{JEFFERSON COUNTY}

Uranium deposits in Jefferson County (table 7) have supplied about 86 percent of the total uranium output from the Front Range and in 1960 were yielding about 300,000 pounds of $\mathrm{U}_{3} \mathrm{O}_{8}$ annually. The total production through 1960 was about 97,850 tons of crude ore that contained $1,301,000$ pounds of $\mathrm{U}_{3} \mathrm{O}_{8}$ (table 1). Although the value of this yield is not known accurately, it is estimated to be about $\$ 6$ million. Most of the deposits and all the significant producing mines are in the Ralston Buttes and Idledale districts; of these, the Schwartzwalder mine in the Ralston Buttes district is by far the most productive. Most of the deposits are in Precambrian rocks; a few are in the upturned Cretaceous sedimentary strata in the foothills along the eastern flank of the range. 
TABLE 7.-Uranium vein deposits in Jefferson County, Colo.

\begin{tabular}{|c|c|c|c|c|c|c|}
\hline \multirow{2}{*}{ Mine or locality } & \multicolumn{3}{|c|}{ Location } & \multirow{2}{*}{ Mine workings } & \multirow{2}{*}{$\begin{array}{l}\text { Clas- } \\
\text { siffca- } \\
\text { tion } \\
\text { of de- } \\
\text { posit }\end{array}$} & \multirow{2}{*}{ Wallrock } \\
\hline & Sec. & T. (8.) & R. (W.) & & & \\
\hline Appel lease.. & 7 & 4 & 70 & Opencut.... & 3 & Pegmatite, biotite gneiss. \\
\hline Ascension & 24 & 3 & 71 & Two adits; trenches.-- & 3 & $\begin{array}{l}\text { Calc-silicate gneiss, bio- } \\
\text { tite gneiss, hormblende } \\
\text { gneiss, amphibolite, peg- } \\
\text { matite. }\end{array}$ \\
\hline Aubrey-Ladwig-...... & 18 & 3 & 70 & $\begin{array}{l}\text { Open pit; shaft with } \\
\text { one level of work- } \\
\text { ings; trenches. }\end{array}$ & 3 & $\begin{array}{l}\text { Pegmatite, garnetiferous } \\
\text { biotite-quartz gneiss, } \\
\text { calc-silicate gneiss. }\end{array}$ \\
\hline Bankers lode... & 9 & 2 & 71 & Not known & 3 & $\begin{array}{l}\text { Boulder Creek Granite, } \\
\text { quartz monzonite, peg- } \\
\text { matite. }\end{array}$ \\
\hline $\begin{array}{l}\text { Black Knight and } \\
\text { Billikin lodes. }\end{array}$ & 3 & 7 & 70 & $\begin{array}{l}\text { 55-ft shaft; several } \\
\text { pits. }\end{array}$ & 3 & $\begin{array}{l}\text { Magnetite-bearing gar- } \\
\text { netiferous biotite gneiss. }\end{array}$ \\
\hline Buckman & 25 & 3 & 71 & Adit; winze........... & 3 & $\begin{array}{l}\text { Biotite gneiss; pegma- } \\
\text { tite. }\end{array}$ \\
\hline $\begin{array}{l}\text { Foothills (Wright } \\
\text { lease). }\end{array}$ & 32 & 4 & 70 & Adit; drifts on 3 levels. & 3 & $\begin{array}{l}\text { Pegmatite, biotite gneiss, } \\
\text { breccia. }\end{array}$ \\
\hline Fork prospect & 19 & 3 & 70 & Small pit & 3 & Calc-silicate gneiss. \\
\hline $\begin{array}{l}\text { Four Corners } \\
\text { (Morrison mine, } \\
\text { Pallaoro lease). }\end{array}$ & $\frac{1}{12}$ & 5 & 70 & 75-ft shaft; drifts...... & 3 & $\begin{array}{l}\text { Sandstone of Dakota } \\
\text { Group. }\end{array}$ \\
\hline Grapevine.-. & 29 & 4 & 70 & $\begin{array}{l}\text { 92-ft shaft; } 55 \text {-ft in- } \\
\text { clined shaft. }\end{array}$ & 3 & $\begin{array}{l}\text { Biotite-quartz gneiss, } \\
\text { amphibolite. }\end{array}$ \\
\hline Ladwig No. 1... & 19 & 3 & 70 & Small pits............... & 3 & $\begin{array}{l}\text { Hornblende gneiss and } \\
\text { amphibolite. }\end{array}$ \\
\hline Ladwig No. 2.... & 19 & 3 & 70 & Small pits....... & 3 & $\begin{array}{l}\text { Hornblende gneiss and } \\
\text { amphibolite. }\end{array}$ \\
\hline Ladwig No. 3 & 19 & 3 & 70 & -....do-.... & 3 & $\begin{array}{l}\text { Hornblende gneiss and } \\
\text { amphibolite. }\end{array}$ \\
\hline Mann No. 1............ & 12 & 5 & 70 & Adit; drifts.............. & 3 & $\begin{array}{l}\text { Sandstone of Dakota } \\
\text { Group. }\end{array}$ \\
\hline Mena_................. & 26 & 2 & 71 & 2 shafts; 3 adits....... & 3 & $\begin{array}{l}\text { Hornblende gneiss, am- } \\
\text { phibolite, biotite gneiss, } \\
\text { calc-silicate gneiss. }\end{array}$ \\
\hline North Star....... & 23 & 2 & 71 & Adit; level.............. & 3 & $\begin{array}{l}\text { Hornblende gneiss, am- } \\
\text { phibolite, biotite gneiss, } \\
\text { pegmatite. }\end{array}$ \\
\hline Ohman mine.......... & 24 & 3 & 71 & Small. & 3 & 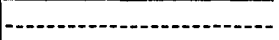 \\
\hline Old Leyden coal mine.. & 28 & 2 & 70 & $\begin{array}{l}\text { Crosscut-adit, } \\
\text { shaft; drifts. }\end{array}$ & & $\begin{array}{l}\text { Sandstone, coal, carbo- } \\
\text { naceous claystone. }\end{array}$ \\
\hline $\begin{array}{l}\text { Schwartzwalder } \\
\text { (Ralston Creek). }\end{array}$ & 25 & 2 & 71 & $\begin{array}{l}4 \text { adit levels; 390-ft } \\
\text { underground shaft } \\
\text { from lowest adit } \\
\text { level; } 3 \text { lower levels } \\
\text { driven from under- } \\
\text { ground shaft. }\end{array}$ & 3 & $\begin{array}{l}\text { Garnetiferous biotite- } \\
\text { quartz gneiss, horn- } \\
\text { blende gneiss, am- } \\
\text { phibolite, calc-silicate } \\
\text { gneiss, fine-grained } \\
\text { mica schist. }\end{array}$ \\
\hline $\begin{array}{l}\text { Union Pacific } \\
\text { prospect. }\end{array}$ & 19 & $\mathbf{3}$ & 70 & $\begin{array}{l}\text { Inclined shaft; short } \\
\text { drift. }\end{array}$ & 3 & $\begin{array}{l}\text { Hornblende gneiss and } \\
\text { amphibolite. }\end{array}$ \\
\hline Unknown prospect.-. & 23 & 2 & 71 & Trenches....... & 3 & $\begin{array}{l}\text { Microcline gneiss, horn- } \\
\text { blende gneiss, am- } \\
\text { phibolite, and biotite } \\
\text { gneiss. }\end{array}$ \\
\hline Unknown prospects.-- & 24 & 2 & 71 & Small pits............. & $\ldots$ & $\begin{array}{l}\text { Microcline gneiss, horn- } \\
\text { blende gneiss, am- } \\
\text { phibolite, and biotite } \\
\text { gneiss. }\end{array}$ \\
\hline
\end{tabular}


TABLe 7.-Uranium vein deposits in Jefferson County, Colo.-Continued

\begin{tabular}{|c|c|c|c|}
\hline Mine or locality & $\begin{array}{l}\text { Strike and dip } \\
\text { of vein or } \\
\text { fissure }\end{array}$ & $\begin{array}{l}\text { Uranium-bearing } \\
\text { minerals }\end{array}$ & Associated minerals \\
\hline Appel lease. & $\begin{array}{l}\mathrm{N}_{65^{\circ}} \mathbf{7 5 W} \text {.; } \\
\end{array}$ & Autunite, torbernite..... & \\
\hline Ascension... & $\begin{array}{l}\text { N. } 55^{\circ} \mathrm{W} \cdot ; \\
70^{\circ}-80^{\circ} \text {. NE. }\end{array}$ & Pitchblende & Pyrite, carbonate minerals, quartz. \\
\hline Aubrey-Ladwig & NW.; NE.- & $\begin{array}{l}\text { Pitchblende, meta-autu- } \\
\text { nite, phosphuranyl- } \\
\text { ite. }\end{array}$ & Pyrite, copper sulfides, fluorite(?). \\
\hline Bankers lode... & $\begin{array}{l}\text { N. } 30^{\circ} \mathrm{E} . ; \\
50^{\circ} \mathrm{SE} \text {. }\end{array}$ & Schroeckingerite........... & \\
\hline $\begin{array}{l}\text { Black Knight and } \\
\text { Billikin lodes. }\end{array}$ & 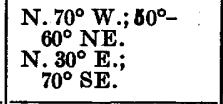 & $\begin{array}{l}\text { Pitchblende, secondary } \\
\text { uranium minerals. }\end{array}$ & $\begin{array}{l}\text { Pyrite, chalcopyrite, bornite, cal- } \\
\text { cite(?). }\end{array}$ \\
\hline Buckman & NE.; steep SE. & $\begin{array}{l}\text { Pitchblende, urano- } \\
\text { phane, uranopilite. }\end{array}$ & \\
\hline $\begin{array}{l}\text { Foothills (Wright } \\
\text { lease). }\end{array}$ & $\begin{array}{r}\text { N. } 20^{\circ}-60^{\circ} \mathrm{W} . ; \\
50^{\circ}-80^{\circ} \mathrm{NE} \text {. }\end{array}$ & Pitchblende, coffinite...- & $\begin{array}{l}\text { Pyrite, carbonates, quartz; K- } \\
\text { feldspar, chlorite. }\end{array}$ \\
\hline Fork prospect.. & NW... & $\begin{array}{l}\text { Pitchblende, uranif- } \\
\text { erous asphaltite. }\end{array}$ & $\begin{array}{l}\text { Pyrite, chalcopyrite, marcasite, } \\
\text { galena, sphalerite, ankerite, } \\
\text { K-feldspar, molybdenite(?). }\end{array}$ \\
\hline $\begin{array}{l}\text { Four Corners } \\
\text { (Morrison mine, } \\
\text { Pallaoro lease). } \\
\end{array}$ & $\begin{array}{l}\text { N. } 40^{\circ} \mathrm{W} \text {; } \\
55^{\circ} \mathrm{SW} \text {. }\end{array}$ & $\begin{array}{l}\text { Uraninite, uraniferous } \\
\text { asphalt. }\end{array}$ & Pyrite, quartz, ilsemannite(?). \\
\hline Grapevine....... & NW.; NE. & Pitchblende. & $\begin{array}{l}\text { Limonite, hematite, pyrite, quartz, } \\
\text { clay minerals. }\end{array}$ \\
\hline Ladwig No. 1.. & NW; ;E.-. & $\begin{array}{l}\text { Pitchblende; } \\
\text { torbernite. }\end{array}$ & Secondary copper minerals. \\
\hline Ladwig No. 2......-. & NW.; NE_......... & Pitchblende, torbernite & Secondary copper minerals. \\
\hline Ladwig No. 3 & N.; dip not known. & Pitchblende.............. & Do. \\
\hline Mann No. 1.. & N. $40^{\circ}$ W.; $55^{\circ} \mathrm{sW}$ & $\begin{array}{l}\text { Uraninite, uraniferous } \\
\text { asphalt. }\end{array}$ & Pyrite, quartz. \\
\hline Mena..... & $\begin{array}{l}N_{43^{\circ}-70^{\circ}} 10^{\circ} \text { NE. } \\
\text {. W.; }\end{array}$ & Pitchblende & $\begin{array}{l}\text { Chalcopyrite, galena, pyrite, chal- } \\
\text { cocite, bornite, niecolite, covel- } \\
\text { lite, native bismuth, native silver } \\
\text { secondary copper minerals, anker- } \\
\text { ite, calcite, quartz, K-feldspar. }\end{array}$ \\
\hline North Star - & $\mathrm{NW}_{.} ; 25^{\circ}-45^{\circ} \mathrm{NE}$. & $\begin{array}{c}\text { Pitchblende, urano- } \\
\text { phane. }\end{array}$ & $\begin{array}{l}\text { Bornite, chalcocite, covellite, mala- } \\
\text { chite, azurite. }\end{array}$ \\
\hline Ohman mine.... & (n)............. & Pitchblende............... & - \\
\hline Old Leyden coal mine. & N. $4^{\circ}$ E.; vertical & $\begin{array}{l}\text { Metatyuyamunite, au- } \\
\text { tunite, uranophane, } \\
\text { coffinite. }\end{array}$ & Pyrite, marcasite. \\
\hline $\begin{array}{l}\text { Sehwartzwalder } \\
\text { (Ralston Creek). }\end{array}$ & See text............. & $\begin{array}{l}\text { Pitchblen de, coffinite, } \\
\text { torbernite, autunite, } \\
\text { metatorbernite, jo- } \\
\text { hannite, meta-autun- } \\
\text { ite, betazippeite. }\end{array}$ & $\begin{array}{l}\text { Pyrite, chalcopyrite, bornite, tetra- } \\
\text { hedrite-tennantite, ch a coci te, } \\
\text { galena, sphalerite, niccolite(?), } \\
\text { emplectite(?), malachite, azurite, } \\
\text { chalcanthite, manganes e oxides, } \\
\text { ankerite, sericite, quartz, K-feld- } \\
\text { spar, calcite, barite. } \\
\end{array}$ \\
\hline $\begin{array}{l}\text { Union Paciflc } \\
\text { prospect. }\end{array}$ & $\begin{array}{l}\text { N. } 15^{\circ}-20^{\circ} \text { W.; } 35^{\circ} \\
\text { NE. }\end{array}$ & Pitchblende............... & $\begin{array}{l}\text { Hematite, tennantite, chalcopyrite, } \\
\text { bornite, chalcocite, covellite, } \\
\text { galena, sphalerite. }\end{array}$ \\
\hline Unknown prospect.... & NW & -.... do & Unidentified copper mineral. \\
\hline Unkmown prospects... & & $\begin{array}{l}\text { Secondary uranium } \\
\text { minerals. }\end{array}$ & \\
\hline
\end{tabular}


TABLE 7.-Uranium vein deposits in Jefferson County, Colo.-Continued

\begin{tabular}{|c|c|c|c|c|}
\hline \multirow{2}{*}{ Mine or locality } & \multicolumn{3}{|c|}{ Analytical data } & \multirow[b]{2}{*}{ Remarks } \\
\hline & Material & $\begin{array}{c}\text { Equiva- } \\
\text { lent } \\
\text { uranium } \\
\text { (percent) }\end{array}$ & $\begin{array}{l}\text { Uranium } \\
\text { (percent) }\end{array}$ & \\
\hline \multicolumn{5}{|l|}{ Appel lease.. } \\
\hline Ascension & Vein........... & $4.8-23.8$ & $6.48-40.18$ & Substantial uranium production. \\
\hline Aubrey'Ladwig-.- & ....do_......... & 1.6 & 1.92 & $\begin{array}{l}\text { Also metatorbernite, metazeune- } \\
\text { rite, and fourmarierite (Todd } \\
\text { New, oral communication, 1956). } \\
\text { Substantial uranium production. }\end{array}$ \\
\hline \multicolumn{5}{|l|}{ Bankers lode } \\
\hline $\begin{array}{l}\text { Black Knight and Billi- } \\
\text { kin lodes. }\end{array}$ & Vein $\ldots . . .$. & $-\ldots$ & $.009-.10$ & $\begin{array}{l}\text { Veins explored by six core drill } \\
\text { holes. }\end{array}$ \\
\hline Buckman............... & -...do do......... & - & $.062-.86$ & \\
\hline Foothills (Wright lease) & & See text_..- & See text..... & $\begin{array}{l}\text { Also, galena, chalcopyrite, marca- } \\
\text { site, sphalerite, tetrahedrite-ten- } \\
\text { nantite(?). Substantial uran- } \\
\text { ium production. }\end{array}$ \\
\hline \multicolumn{5}{|l|}{ Fork prospect............. } \\
\hline $\begin{array}{l}\text { Four Corners (Morrison } \\
\text { mine, Pallaoro lease). }\end{array}$ & ----- & ----- & - & Substantial uranium production. \\
\hline Grapevine............. & - & $-\ldots$ & 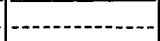 & Do. \\
\hline Ladwig No. 1 . . ............. & Vein & $-\ldots$ & 1.36 & \\
\hline Ladwig No. 2.... & Vein.......... & - & .30 & \\
\hline \multicolumn{5}{|l|}{ Lad wig No. 3} \\
\hline Mann No. 1 & 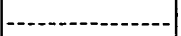 & $\ldots$ & - & Substantial uranium production. \\
\hline Mena................ & $\begin{array}{l}\text { Vein in old } \\
\text { shaft. } \\
\text { Vein at site of } \\
\text { portal, north } \\
\text { adit. }\end{array}$ & $\begin{array}{r}.28 \\
.2 .\end{array}$ & $\begin{array}{l}.004-.31 \\
.24\end{array}$ & Do. \\
\hline North Star................ & Vein.......... & - & $.002-.51$ & \\
\hline Ohman mine................ & - & $-\cdots$ & 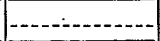 & Small production. \\
\hline Old Ieyden coal mine..... & - & (1) & $.10-.70$ & Substantial uranium production. \\
\hline $\begin{array}{l}\text { Schwartzwalder } \\
\text { (Ralston Creek). }\end{array}$ & $\begin{array}{l}\text { Vein and } \\
\text { coarse brecia }\end{array}$ & $.012-5.7$ & $.009-6.36$ & Do. \\
\hline $\begin{array}{l}\text { Union Pacific } \\
\text { prospect }\end{array}$ & - & 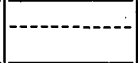 & & $\begin{array}{l}\text { Also, emplectite(?), pyrite, anker } \\
\text { ite, K-feldspar, and chlorite. }\end{array}$ \\
\hline \multicolumn{5}{|l|}{ Unknown prospect....... } \\
\hline Unknown prospects_...... & & & & \\
\hline
\end{tabular}

1 Uraniferous brecciated and silicifled coal. 
Uranium was recognized in the county as early as 1874 but was not actively sought until more than 70 years later. After discoveries in the Ralston Buttes area by Fred Schwartzwalder in 1949, the search for uranium in the county was intensified, and several significant deposits were found in the span of a few years. Most of the discoveries were made by prospectors but a few, especially in the Golden Gate Canyon area of the Ralston Buttes district, were made by geologists of the U.S. Geological Survey (Adams and others, 1953; Adams and Stugard, 1956a, 1956b, 1956c). Prospecting and exploration were aided by detailed geologic studies begun in 1953 by the U.S. Geological Survey in the Ralston Buttes quadrangle and by local studies, particularly in the Ralston Buttes and Idledale districts, by personnel of the U.S. Atomic Energy Commission and the Defense Minerals Exploration Administration.

The uranium deposits of Jefferson County are all of class 3. They contain both uraninite and coffinite as the valuable ore minerals, and none have yielded other metals in economic quantities, although some, especially in the Ralston Buttes district, might do so in the future. Ore bodies in several of the mines are large, and some contain several thousand tons of ore.

\section{RALSTON BUTTES DISTRICT}

The Ralston Buttes district in northwestern Jefferson County is 12 miles west of Denver, on the east flank of the Front Range. As defined in this report, it coincides in area with the Ralston Buttes $7 \frac{1}{2}$ minute quadrangle. The district ranks first in uranium production among the mining districts of the Front Range, having supplied about 80 percent of the total output of $\mathrm{U}_{3} \mathrm{O}_{8}$. From 1953, when the first shipment of uranium ore was made, through 1960, about 82,200 tons of ore that contained about $1,211,000 \mathrm{lb}$ of $\mathrm{U}_{3} \mathrm{O}_{8}$ (table 8) was shipped from five mines in the district. Although the value of this yield is not known accurately, it is at least $\$ 5 \frac{1}{2}$ million.

The economic geology of uranium deposits in the Ralston Buttes district has been described in greater or lesser detail by Adams, Gude, and Beroni (1953); Bird and Stafford (1955); Adams and Stugard (1956a, 1956b, 1956c); Bird (1956, 1957a, 1957b); R. C. Derzay and A. G. Bird (written communication, 1957); J. D. Schlottmann and A. V. Green (written communication, 1957); and R. J. Wright and D. L. Everhart (in Del Rio, 1960, p. 349-352). A comprehensive study of the general geology and uranium deposits of the Ralston Buttes district was made by the U.S. Geological Survey during the period 1953-57. The preliminary results of this study have been published (Sheridan, 1956; Sheridan and otbers, 1958), and a more detailed report is being prepared by Sheridan Maxwell, Albee, and Van Horn. 
TABLE 8.-Uranium production from the Ralston Buttes district, Jefferson County, Colo., 1953-60

[Production data are published with the permission of mine owners. Except where noted, all data were compiled from records of U.S. Bur. Mines, Denver, Colo.].

\begin{tabular}{|c|c|c|c|c|}
\hline Mine & Year & $\begin{array}{l}\text { Crude ore } \\
\text { shipped } \\
\text { (short tons) }\end{array}$ & $\begin{array}{c}\text { Grade } \\
\text { (percent } \\
\left.\text { U }_{3} \mathrm{O}_{8}\right)\end{array}$ & $\underset{\text { (pounds) }}{\mathrm{U}_{3} \mathrm{O}_{8}}$ \\
\hline \multirow[t]{2}{*}{ Ascension } & \multirow{2}{*}{\begin{tabular}{|l}
1956 \\
$1957-59$ \\
1860
\end{tabular}} & 439.51 & .23 & $2,063.44$ \\
\hline & & 1,010 & .27 & $5, \mathbf{3 8 5}$ \\
\hline $\begin{array}{l}\text { Total } \\
\text { Average }\end{array}$ & $\cdots$ & $1,449.51$ & .26 & $7,448.44$ \\
\hline \multirow{2}{*}{$\begin{array}{l}\text { Aubrey Ladwig lease } \\
\text { Total_._. } \\
\text { Average }\end{array}$} & $\begin{array}{l}1955 \\
1956 \\
1957-60\end{array}$ & $\begin{array}{r}386.72 \\
1,554.96 \\
\end{array}$ & .31 & $\begin{array}{r}2,419.80 \\
7,107.35 \\
\end{array}$ \\
\hline & & $1,941.68$ & .25 & $9,527.15$ \\
\hline \multirow{2}{*}{$\begin{array}{l}\text { Mena } \\
\text { Total } \\
\text { Average }\end{array}$} & \begin{tabular}{|l}
1956 \\
1957 \\
1958 \\
1960
\end{tabular} & $\begin{array}{l}247.70 \\
242.31 \\
271 \\
129 \\
109\end{array}$ & $\begin{array}{l}.32 \\
.16 \\
.32 \\
.31 \\
.23\end{array}$ & $\begin{array}{l}1,603.10 \\
781.99 \\
1,739 \\
795 \\
511\end{array}$ \\
\hline & & 01 & .27 & $5,430.09$ \\
\hline \multirow{2}{*}{$\begin{array}{l}\text { Ohman (Nare lease) } \\
\text { Total. } \\
\text { Average }\end{array}$} & 1959 & $\begin{array}{r}5 \\
192\end{array}$ & $\begin{array}{r}1.18 \\
.23\end{array}$ & $\begin{array}{l}118 \\
870\end{array}$ \\
\hline & $-\cdots$ & 197 & & 988 \\
\hline \multirow{2}{*}{$\begin{array}{l}\text { Schwartzwalder. } \\
\\
\quad \text { Total } \\
\text { Average }\end{array}$} & 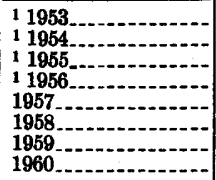 & $\begin{array}{r}51.29 \\
660.86 \\
848.77 \\
11,151.61 \\
14,982.75 \\
14,631 \\
17,146 \\
18,188\end{array}$ & $\begin{array}{l}1.32 \\
.70 \\
.66 \\
.54 \\
.71 \\
.78 \\
.92 \\
.80\end{array}$ & $\begin{array}{r}1,354.06 \\
9,265.26 \\
11,237.71 \\
119,857.09 \\
211,524.05 \\
228,168 \\
315,510 \\
291,162\end{array}$ \\
\hline & ---1 & $\begin{array}{r}77,660.28 \\
\hdashline-1 .\end{array}$ & .76 & $1,188,078.17$ \\
\hline $\begin{array}{l}\text { Cotal for } R \\
\text { Iverage for }\end{array}$ & $\begin{array}{l}1953-60 \\
1953-60\end{array}$ & $82,247.48$ & .74 & $1,211,471.85$ \\
\hline
\end{tabular}

1 Production data for Schwartzwalder mine, 1953-55, were complled from records of Div. of Raw Materials, U.S. Atomic Energy Comm., Denver, Colo.

\section{GENERAI GEOLOGY}

Metamorphic and igneous rocks of Precambrian age form most of the bedrock of the district (fig. 20). These rocks are overlain unconformably in the northeastern part of the district by sedimentary rocks of Paleozoic and Mesozoic age. The Precambrian rocks are dominantly an interlayered succession of mica schist, hornblende gneiss, amphibolite, quartzite, calc-silicate gneiss, and several varieties of feldspathic and biotitic gneisses. The rocks in this succession, believed to be mainly metasedimentary in origin, are intruded in the western and northern parts of the district by Precambrian igneous rocks, including granodiorite-quartz monzonite, quartz monzonite, and hornblende diorite and associated hornblendite. Other igneous rocks, not shown in figure 20 , include Precambrian pegmatites and 

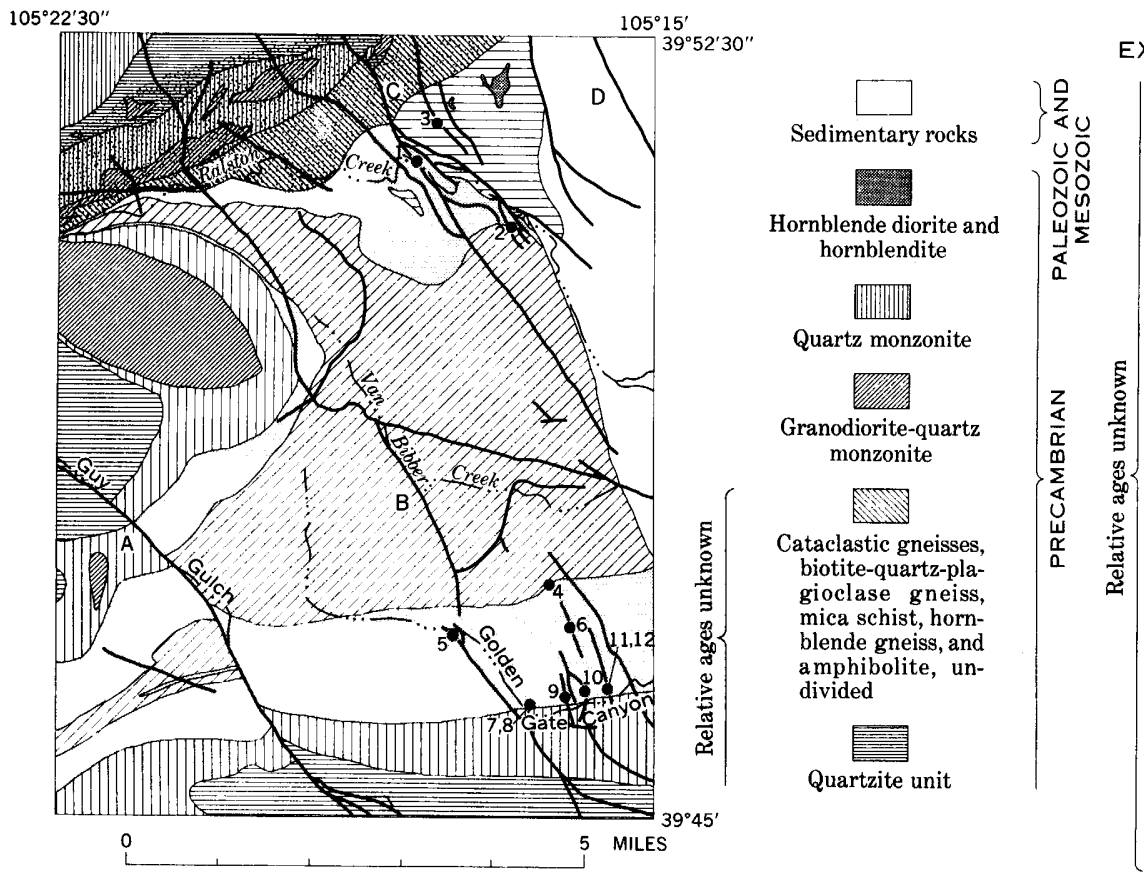

EXPLANATION

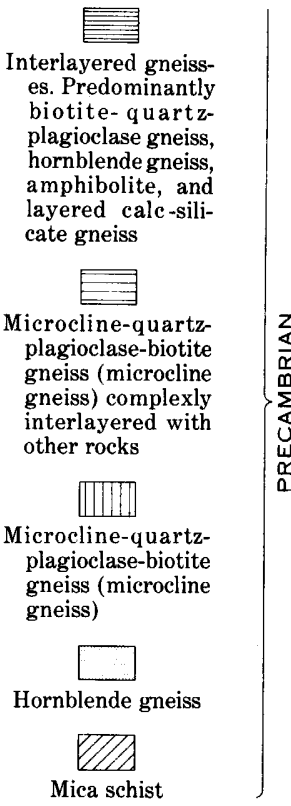

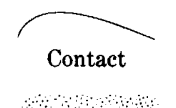

Zône of cataclastic deformation

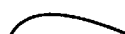

Breccia-reef fault or fracture zone

$\begin{array}{cc}z & A \\ \frac{\alpha}{\alpha} & \text { Junction Ranch fault }\end{array}$ system

B

Hurricane Hill faul system$$
\text { C }
$$

Rogers fault system D

Livingston fault system

$\bullet_{10}$

Uranium locality Mica schist

Fraure 20.-Simplifled geologic map of the Ralston Buttes district, Jefferson County, showing the principal uranium deposits. Geology by D. M. Sheridan, C. H. Maxwell, A. L. Albee, and Richard Van Horn, 1953-1958. List of mines and prospects: 1. Mena mine; 2. Schwartzwalder mine; 3. North Star mine; 4, Aubrey Ladwig lease; 5. Ascension mine; 6. Fork prospect; 7. Buckman adit; 8. Ohman mine; 9. Ladwig no. 1; 10. Union Pacifle prospect; 11. Ladwig no. 3; 12. Ladwig no. 2. Names of fault systems taken from their northwestward extensions (Lovering and Goddard, 1950, pl, 2). 
dikes of hornblende-biotite lamprophyre and Laramide leucosyenite in a dike in the Guy Gulch area, and sills of monzonite in the sedimentary rocks.

The predominant trend of layering, foliation, and the axial planes of major folds in the Precambrian rocks is east to northeast. This orientation is a product of a major plastic deformation accompanied by intrusion of the principal igneous rocks. The rocks in a northeastward-trending zone in the northern part of the quadrangle were deformed further in a later episode of Precambrian deformation characterized mainly by cataclasis. Four prominent northwestwardtrending fault systems ${ }^{1}$ cross the district. These comprise the breccia reefs and related faults and intensely fractured areas. These fault systems probably formed originally during late Precambrian time but underwent renewed movements during the Laramide revolution. In the northwestern part of the district, the fault breccias are cemented by quartz, fluorite, and hematite, but in the remainder of the district, they are more commonly cemented by ankerite and potassic feldspar and contain varying amounts of quartz and altered wallrock fragments.

\section{ECONOWIC GEOLOGY}

Uranium deposits in the Ralston Buttes district are concentrated in two areas. One group of deposits is in the Ralston Creek area and in the Rogers fault system (fig. 20). The other is in the Golden Gate Canyon area and is in the complexly branching southeastward extension of the Hurricane Hill fault system. In both areas the wallrocks are predominantly hornblende gneiss, amphibolite, calc-silicate gneiss, biotite gneiss, and garnetiferous biotite-quartz gneiss. Although other occurrences of uranium minerals and of abnormal radioactivity due to uranium are known in the district, none of these outside the two major areas had yielded any uranium ore by the end of 1960 .

The uranium deposits of the district are of class 3 , according to the classification used in this report. They are mainly hydrothermal veins, and with only one or two minor exceptions, they occupy openings in breccias and fractures related to the northwestwardtrending faults.

The ore contains pitchblende, minor amounts of secondary uranium minerals, and, in one mine, coffinite, in association with variable but generally small amounts of paragenetically younger base-metal sulfide minerals. The gangue consists of carbonate minerals, potassic feldspar, and, in some veins, quartz. Although sparse, the metallic minerals accompanying the uranium are varied; they include pyrite,

\footnotetext{
1 In this report, the term "system" is applied to groups of spatially related faults and fractures, some of which are themselves fault zones.
} 
chalcopyrite, bornite, chalcocite, covellite, sphalerite, galena, tetrahedrite-tennantite, native bismuth, native silver, niccolite, marcasite, malachite, azurite, hematite, and emplectite(?). Molybdenite and pyrrhotite have been observed in the wallrocks at the Schwartzwalder mine but have not been identified in polished sections of the ore. Anomalous amounts of vanadium and molybdenum have been noted in some ore samples from the district but the minerals that contain them have not been recognized. Uraniferous asphaltite occurs in a pitchblende-bearing vein at the Fork prospect. The asphaltite is probably related to oil seepage from younger sedimentary rocks which underlie a reverse fault that dips westward toward the district from surface exposures a mile or so to the east.

The vein minerals typically fill spaces between breccia fragments or occupy openings in a complex network of fractures in cemented breccia. They were deposited on the breccia fragments as generally thin coatings, and they have a banded crustiform appearance. Parts of the veins are vuggy, but elsewhere the vein material has a dense massive appearance. Original vugs were apparently reduced in number and size by repeated fracturing and postore brecciation.

Individual ore bodies range in size from small pods or lenses containing less than 50 tons of ore to large shoots containing several thousand tons. The deposits range in thickness from individual veinlets a fraction of an inch thick to large bodies composed of complexly branching veins or coalescing major veins that have mining widths of as much as 35 feet. The long dimension of the ore shoots is commonly downdip.

The average grade of all ore shipped from the Schwartzwalder mine, the largest producer in the district, has been about 0.76 percent $\mathrm{U}_{3} \mathrm{O}_{8}$ (table 8). The average grade of ore shipped from the other mines in the district has been about 0.26 percent $\mathrm{U}_{3} \mathrm{O}_{8}$. Although base and precious metals are relatively sparse in the ore by comparison to deposits of class 2, parts of some deposits in the Ralston Buttes district contain appreciable amounts of these metals. For example, a grab sample of ore from the Mena mine contained 10.8 percent copper, 5.8 percent bismuth, and 43.6 ounces of silver per ton. Samples in a group of 30 channel samples from the Schwartzwalder mine contained as much as 1.07 percent copper, 0.077 percent $\mathrm{V}_{2} \mathrm{O}_{5}, 0.19$ percent zinc, 1.63 percent lead, 0.95 percent molybdenum, and 7.1 ounces of silver per ton. According to records of the U.S. Bureau of Mines, several shipments of ore from the Schwartzwalder and Mena mines contained as much as 0.11 percent $\mathrm{V}_{2} \mathrm{O}_{5}$.

Localization of the uranium deposits in the district can be attributed to two geologic factors-a favorable structural environment and favorable host rocks. The deposits in each of the two major producing 
areas in the district are located where a northwestward-trending fault system splits into a complex network of intersecting and branching faults and fractures. Within such areas, most of the deposits appear to be localized in rocks of the hornblende gneiss unit (fig. 20), which are rich in hornblende, biotite, and, in places, garnet. The localization of deposits in the hornblende gneiss unit probably is a reflection of physical characteristics, as these rocks are competent and tend to yield open spaces upon brecciation. Further, where the unit consists of interlayers of rocks of different competency, the faults are deflected as they pass from one rock type into another, forming cymoid curves and branching structures. In addition to these factors, however, the chemical nature of the hornblende gneiss unit may also have influenced deposition of vein matter, for noteworthy deposits appear to belacking elsewhere in the district where faults cut competent rock units of different mineralogic composition. Earlier, Adams and Stugard (1956c, p. 208) suggested that wallrocks containing abundant minerals rich in ferrous iron were especially favorable chemically for the deposition of uranium minerals.

\section{SCEWARTZWALDER WINE}

The Schwartzwalder mine, which also has been called the Ralston Creek mine, is on the southwest side of Ralston Creek in the northeastern part of the Ralston Buttes district (2, fig. 20). It has been the principal source of uranium ore in the district and in the entire Front Range, having yielded 77,660 tons of crude ore that contained an average of 0.76 percent $\mathrm{U}_{3} \mathrm{O}_{8}$ (table 8).

Although the property had been prospected for copper late in the 19th century, the first discovery of uranium minerals there was made by Fred Schwartzwalder in 1949. He began mining along the dip of his discovery vein, now known as the Ralston Creek (or Flat) vein, and made his first shipment in November 1953-51.29 tons containing 1.32 percent $\mathrm{U}_{3} \mathrm{O}_{8}$ (table 8). Additional uranium deposits were discovered on the property during an exploration contract with the Defense Minerals Exploration Administration in 1953-54 and during an exploration program of the U.S. Atomic Energy Commission in 1954-55. Since February 1956, the property has been leased and operated by the Denver-Golden Oil and Uranium Co., and in recent years monthly shipments have averaged well over 1,000 tons of ore containing more than 0.70 percent $\mathrm{U}_{3} \mathrm{O}_{8}$.

The Schwartzwalder mine will be described in detail in a separate report on the Ralston Buttes district, and only a summary is included here. The writers' studies of the mine ended in 1956, when it included only three levels, but A. G. Bird and J. D. Schlottmann (oral communications, 1961) have provided supplementary information on workings driven between 1956 and 1961. 


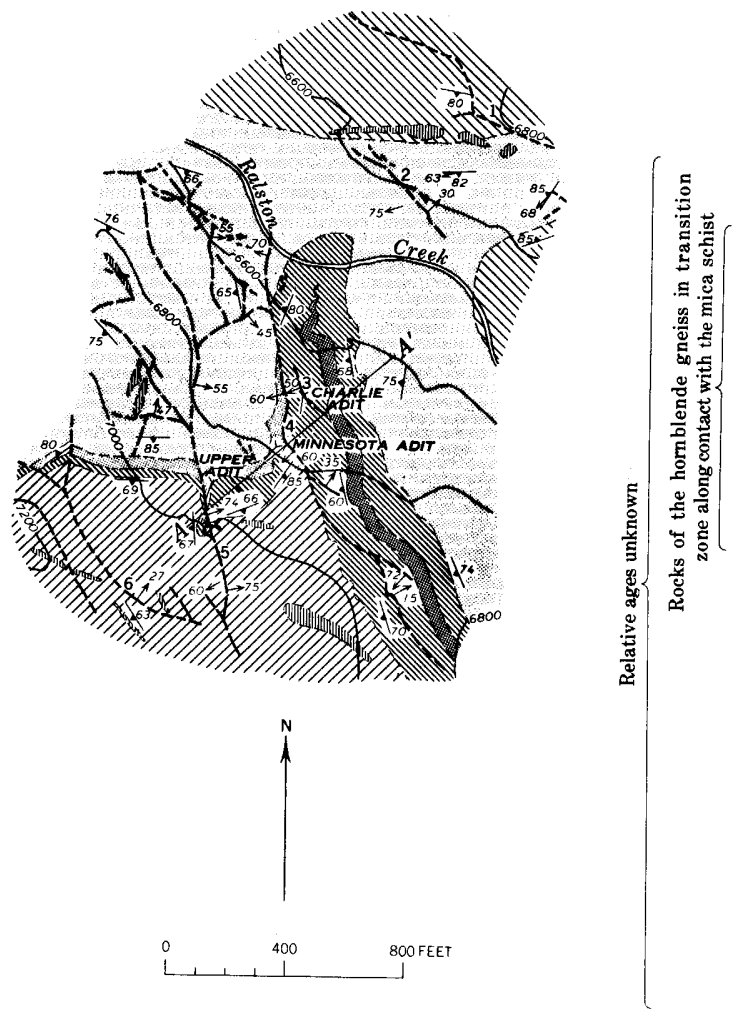

QUATERNARY DEPOSITS
NOT SHOWN

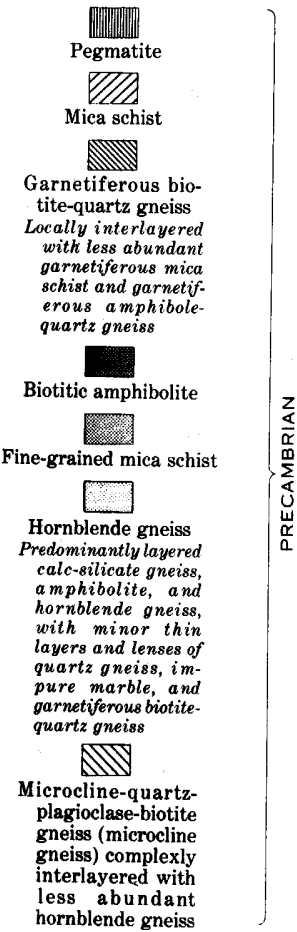

Contact

Dashed where approx

shart dashed where inferred

$T_{45}$

Breccia-reef fault or vein fissure, showing dip

Dashed whereapprox short dashed where inferred

Named fault and vein fissures:

1. Rogers breccia-reef

fault.

ana vein fis-

3. Washington vein

4. Illinois vein fissure

6. Nebraska(?) vein

Strike and $\stackrel{66}{\operatorname{dip}}$ of foliation

Bearing and plunge of lineation ${ }^{63} \times 82$

Strike and dip of foliation and bearing and plung of lineation

$$
\text { Portal of adit }
$$

Frover 21. - Simplifled geologic map of the Schwartzwalder mine area, Ralston Butte district, Jefferson County. Section $A-A^{\prime}$ shown In flgure 22. Geology and topography by D. M. Sheridan, 1956. Base surveyed by planetable methods by D. M. Sheridan, W. E. Willging, and C. H. Maxwell, 1955-1956. 

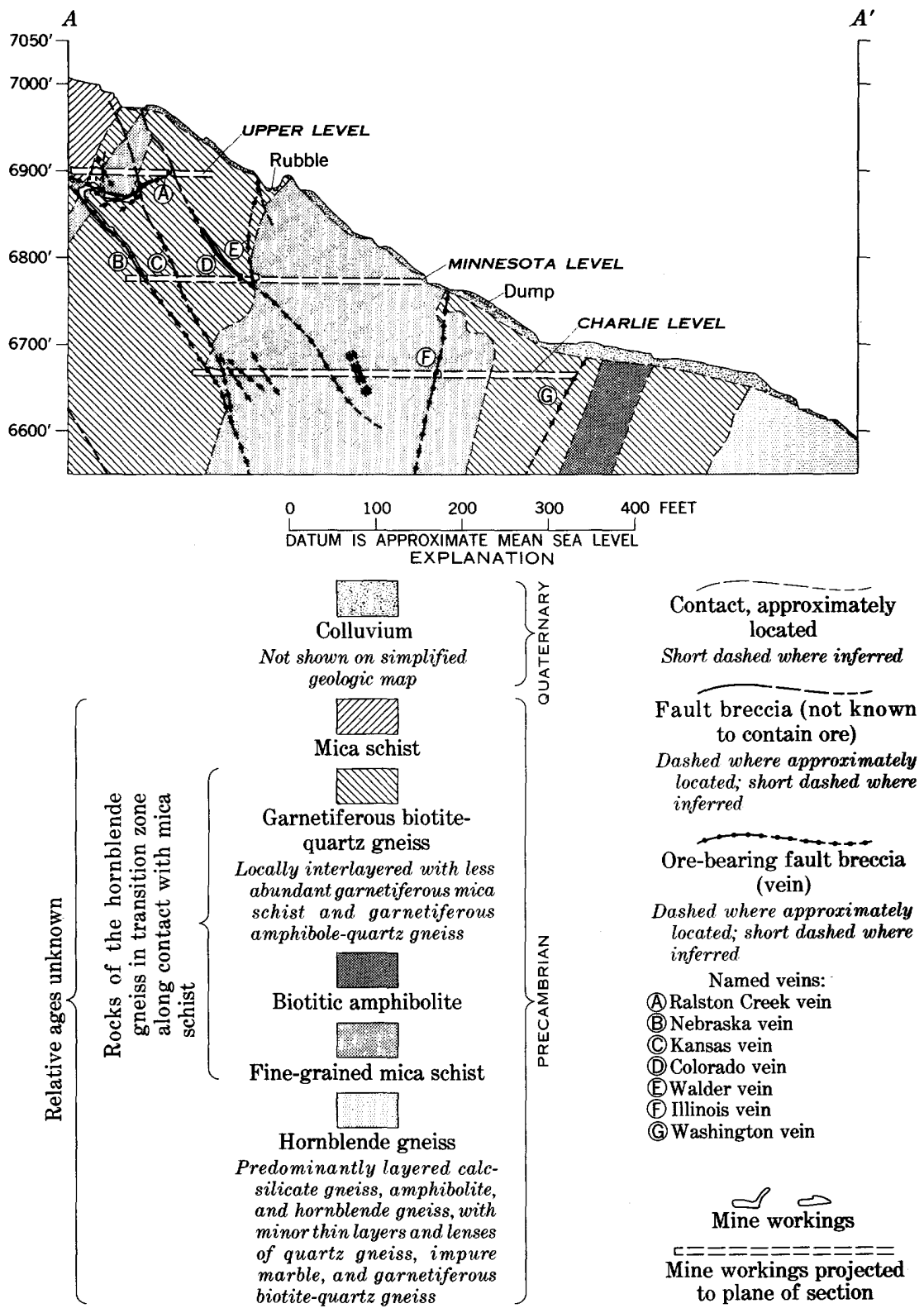

FIGURE 22.-Geologic section of the Schwartzwalder mine, Ralston Buttes district, Jefferson County. Line of section shown on figure 21. Geology by D. M. Sheridan, 1956. 
The mine workings studied by the writers in 1956 consisted of three levels opening from the Charlie, Minnesota, and Upper adits (fig. 21), ranging in altitude from about 6,662 to 6,894 feet. The workings included two raises, numerous stopes, and about 1,900 feet of adits, crosscuts, and drifts. After 1956, the Steve level, which is about 116 feet vertically below the Charlie level, was driven from a portal located about 300 feet N. $20^{\circ} \mathrm{E}$. from the portal of the Charlie adit, and an underground shaft was sunk from the Steve level to a depth of 390 feet. Three lower levels were driven from the shaft, at depths of 125,250 , and 358 feet.

The bedrock in the mine area is in three main units-mica schist unit in the southern part of the area, hornblende gneiss in the central part, and, microcline gneiss interlayered with less abundant hornblende gneiss in the northern part (fig. 21). The hornblende gneiss is separated from the mica schist by a transition zone 50-300 feet wide that consists dominantly of garnetiferous biotite-quartz gneiss and lenses of fine-grained mica schist and biotitic amphibolite. Streaks of quartz gneiss, garnetiferous mica schist, and garnetiferous amphibole-quartz gneiss also exist in the transition zone but are not shown separately in figure 21. The mine workings in 1956 (fig. 22) were largely in this transition zone. Most of the rocks in the zone contain pyrite and pyrrhotite which are apparently unrelated to the pitchblende-bearing veins. Iron and manganese oxides produced by weathering of these sulfides and garnet has stained many of the rocks so that they resemble the gossan of the veins.

The rocks in the vicinity of the mine are folded into a fairly large syncline and an adjacent small anticline, the axes of which plunge steeply southwest. The trough of the syncline is outlined by the large nose of garnetiferous biotite-quartz gneiss that extends across Ralston Creek in the central part of the area; the nose of the anticline is defined by the same garnetiferous map unit south of the portal of the Upper adit. East of the Illinois vein, the syncline is tight, nearly isoclinal, and in part overturned; southwest of the vein the syncline is more open. North of Ralston Creek the axial plane of the syncline apparently bends sharply to the northeast, as defined by the northeastward-trending lobe of hornblende gneiss (fig. 21). The predominant plunge and bearing of lineations in the area is $60^{\circ}-75^{\circ} \mathrm{S} .65^{\circ}-70^{\circ} \mathrm{W}$., which probably is about parallel to the major fold axes.

Numerous faults and fracture zones of the Rogers fault system lie within the area, principally between two major bounding faults (fig. 20 ). One of the bounding faults lies north of Ralston Creek, opposite the mine (fig. 21). It dips steeply northeast and has an apparent horizontal displacement of about 2,200 feet as a result of several movements that displaced the northeast block upward and to the 
southeast. The other bounding fault lies about half a mile southwest of the mine. The block between the bounding faults is approximately 3,500 feet wide, trends about N. $50^{\circ} \mathrm{W}$., and is cut by a group of complexly branching and splitting subsidiary faults. Two of the most persistent of the subsidiary faults are occupied by the Colorado and Illinois veins (fig. 21 ), which trend about $\mathrm{N} .10^{\circ} \mathrm{W}$. and dip steeply east and west respectively. "The Nebraska vein as known in the mine is not certainly identifiable at the surface but may flatten and continue as the vein labeled Nebraska(?), which dips $27^{\circ} \mathrm{NE}$. The history of movements along the various faults is complex, and at least three episodes of fracturing are recognized, but the net displacements along the subsidiary faults appear to be small. The geologic section (fig. 22) suggests reverse-fault movement along the Colorado and Nebraska veins and probably along the Illinois.

The principal veins of the mine are illustrated in figure 22. The Colorado and Kansas vein fissures were virtually barren of uranium on the Upper level but contained ore below that level. In the deeper workings driven since 1956, the Nebraska, Illinois, and Washington veins have proved to be persistent and productive. Some of the bodies of ore-bearing breccia are localized by cymoid curves in the veins, as will be illustrated in a separate report on the Ralston Buttes district.

The pitchblende-bearing veins of the Schwartzwalder mine typically are dark fault breccias and adjoining fractured wallrocks which are coated, filled, and veined by the ore minerals. A little pitchblende occurs also in thin veinlets along some small faults and fractures. The veins range in thickness from a fraction of an inch to as much as 8 feet, but in places where they coalesce or branch repeatedly, stopes as much as 35 feet wide have been made. The ore within the thick ore shoots generally is an erratic mixture of materials of high and low grade, but much of it has proved on mining to average more than 0.70 percent $\mathrm{U}_{3} \mathrm{O}_{8}$. The breccia ores are generally highest in grade and follow the principal fractures, whereas the shattered rock between the fractures contains ore of lower grade. Dimensions of the ore shoots had not yet been determined in 1956, and some are still not known. The shoots rake steeply and typically have their longest dimension roughly parallel to the dip. Some have rake lengths of several hundred feet.

The vein material contains pitchblende and coffinite and generally lesser but locally abundant quantities of sulfide minerals in a gangue of ankerite, potassic feldspar, calcite, and quartz. The sulfide minerals are pyrite, chalcopyrite, tetrahedrite-tennantite, bornite, chalcocite, galena, sphalerite, and niccolite(?). The coffinite and niccolite(?) were reported from the lower workings by J. D. Schlottmann (oral communications, 1960 and 1961). Secondary uranium 
minerals occur only on some of the veins and to shallow depth; and in general, they have been negligible sources of the uranium produced.

Much of the vein material has been so brecciated and sheared that a detailed paragenetic history is difficult to establish. In general, however, vein filling appears to have taken place in at least three stages. The earliest minerals to form were ankerite, potassic feldspar, pitchblende, and some quartz and pyrite. Following renewed fracturing and brecciation, the base-metal sulfides were deposited, along with ankerite and quartz. Finally, calcite and pyrite were deposited during late movements along some of the veins.

\section{OTHER MTNES}

Eleven uranium mines and prospects in addition to the Schwartzwalder mine are shown on the map of the Ralston Buttes district (fig. 20). Four of these have produced uranium ore. These are described briefly below, with the exception of the Ohman mine for which we have no geologic data. Some of the mines and prospects were described previously in reports by Adams, Gude, and Beroni (1953) and Adams and Stugard (1956a, 1956b, 1956c). All except one (the relatively new Ohman mine) will be described in a separate report on the Ralston Buttes district.

Ascension mine.-The Ascension mine, located near Golden Gate Canyon, in the southeastern part of the district (5, fig. 20), has produced about 1,450 tons of crude ore that contained an average of about 0.26 percent $\mathrm{U}_{3} \mathrm{O}_{8}$ (table 8). In 1956 the mine consisted of a main adit at an altitude of 6,955 feet that had 425 feet of workings and a short adit 70 feet higher. Rocks of the mine area are calcsilicate, hornblende, and other gneisses, all intruded by numerous bodies of pegmatite. The gneisses trend N. $70^{\circ}-90^{\circ} \mathrm{E}$. and dip steeply both to the north and the south. The breccia reef faults and associated fractures in the mine area belong to the Hurricane Hill fault system. Major faults form a V-pattern, joining southeast of the mine. The southwesternmost fault, along which the main workings have been driven, trends N. $62^{\circ} \mathrm{W}$. and dips $66^{\circ}-85^{\circ} \mathrm{NE}$. over most of its extent in the mine area, but is vertical and trends N. $32^{\circ} \mathrm{W}$. farther to the northwest. The other main fault lies north of the main adit. It trends N. $48^{\circ} \mathrm{W}$. and dips $64^{\circ}-75^{\circ} \mathrm{NE}$. near the mine but farther southeast splits into two subparallel branches that trend $\mathrm{N} .15^{\circ} \mathrm{W}$. The apparent relative movement along the major faults was right lateral with normal-fault dip-slip components. The apparent displacements are several hundred feet. Pitchblende, associated with varying amounts of carbonate minerals and quartz, occurs as colloform coatings on breccia fragments along the faults and as thin stringers along subsidiary fractures. Exposures of urani- 
ferous breccia in the workings range from 12 to 30 inches wide. The main adit exposes two ore shoots, each at least 20 feet in strike length and probably much longer in the downdip dimension. Stringers and veinlets in the hanging wall near these shoots are very rich; grab samples of some contained as much as 40 percent uranium.

Other radioactive fault breccias, some of which dip at angles as low as $34^{\circ}$, are exposed elsewhere in the mine area. A grab sample of breccia at the upper adit contained 0.37 percent uranium.

Aubrey Ladwig lease.-The Aubrey Ladwig lease, midway between Van Bibber Creek and Golden Gate Canyon in the southeastern part of the district (4, fig. 20 ), has yielded about 1,940 tons of crude ore that contained an average of about 0.25 percent $\mathrm{U}_{3} \mathrm{O}_{8}$ (table 8). In 1956 the workings consisted of an open pit, a 74-foot shaft collared in the northeastern part of the pit, and about 230 feet of drifts and crosscuts. The principal rocks in the mine area are garnetiferous biotite-quartz gneiss and pegmatite. The foliation strikes northeastward and is vertical or dips steeply southeast or northwest. The mine lies between major strands of the Hurricane Hill fault system, but only small faults have been recognized in its immediate vicinity. The most prominent fractures and faults in the mine area strike N. $40^{\circ}-60^{\circ}$ W., dip $15^{\circ}-47^{\circ}$ NE., and on the 74 -foot level contain as much as 18 inches of breccia. A less prominent set of fractures trends northeastward and dips steeply; some of these fractures displace the breccia on the 74-foot level. In the ore mined from the open pit, pitchblende and secondary uranium minerals, principally meta-autunite, occurred in pods and as fillings and coatings in fractures near the contact between pegmatite and gneiss. Pitchblende-bearing fault breccia on the 74-foot level forms an ore shoot 17 feet in strike length and about 1 foot thick. The shoot was stoped up the dip for 40 feet, and drill data suggest that it extends at least 30 feet downdip from the level. Although the breccia body dips only $30^{\circ} \mathrm{NE}$. on the 74-foot level, it steepens upward to a dip of $47^{\circ}$, and the drill data suggest that it steepens below the level as well. A channel sample across $8 \frac{1}{2}$ inches of the breccia contained 1.92 percent uranium. Pyrite is fairly common in the ore, but base-metal sulfides are rare.

Mena mine.-The Mena mine, known formerly as the Hoffmeister prospect and the Nigger shaft, is beside Ralston Creek in the northeastern part of the district (1, fig. 20). It has yielded about a thousand tons of crude ore that contained an average of about 0.27 percent $\mathrm{U}_{3} \mathrm{O}_{8}$ (table 8). When examined in 1956, the principal mine workings were the North and South adits, with a combined length of 344 feet; since then, a vertical shaft has been excavated and drifts have been driven from it. The rocks in the vicinity of the mine are an inter- 
layered succession of hornblende gneiss, amphibolite, and biotitequartz-plagioclase gneiss with lesser amounts of calc-silicate gneiss. The foliation strikes $N .60^{\circ}-90^{\circ} \mathrm{W}$. and dips at moderate angles southwest. The rocks are cut by a group of northwestward-trending breccia reef faults of the Rogers fault system. The Mena vein, consisting of mineralized breccia, occupies one of these faults. It has been traced on the surface for 2,000 feet and merges at its extremities with other breccia-reef faults. The vein strikes $\mathrm{N} .10^{\circ}-35^{\circ} \mathrm{W}$., dips $43^{\circ}-70^{\circ} \mathrm{NE}$., and ranges in thickness from 6 inches to 3.5 feet. Other prominent fault breccias in the mine area are as much as 35 feet wide and trend $\mathrm{N} .45^{\circ}-60^{\circ} \mathrm{W}$. Pitchblende occurs as colloform coatings on rock fragments and fracture surfaces and as a network of thin black stringers in the rather dense tan breccia of the Mena vein. Associated with it in one place or another are native bismuth, galena, chalcopyrite, pyrite, chalcocite, bornite, covellite, niccolite, and secondary copper minerals. In addition, native silver has been observed in workings of the new shaft (J. W. Walsh, oral communication, 1957). The gangue minerals are ankerite, potassic feldspar, quartz, and calcite. As exposed in the North adit in 1956, the main ore shoot had a strike length of about 65 feet, was 1-3.5 feet thick, appeared to rake steeply, and had been worked through a rake length of 65 feet, with the terminus still unestablished. Evidence of two other ore shoots was seen in uraniferous breccia exposed nearer the portal of the North adit and at the portal of the South adit.

\section{DLEDALE DISTRICT GENERAL FEATURES}

The Idledale district constitutes an area of about a square mile at the west edge of the community of Idledale, along Bear Creek, in Jefferson County. Uranium was discovered there in 1955, and by 1960 the district contained two producing mines, the Foothills and the Grapevine, as well as several promising prospects (fig. 23). The total uranium production from the district through 1960 is given in table 9.

The geology of the district and adjacent areas has not been studied in detail but is partly known from reconnaissance mapping by Boos and Boos (1957, fig. 8) and by J. D. Schlottmann (fig. 23, this report). The Precambrian country rocks are dominantly migmatites and granitic gneisses, which Boos and Boos (1957, fig. 8) have termed the Mount Morrison Formation, but include layers and lenses of biotite gneisses, amphibolite, and other rocks. The gneisses strike westnorthwestward and dip moderately steeply either northeastward or southwestward. The structure of the rocks is complex but poorly known. Two major fault zones, the Bear Creek and the Sawmill Gulch shear zones as defined by Boos and Boos, transect the 
EXPLANATION

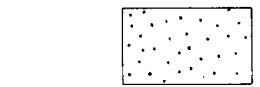

Area of intense limonite alteration

$$
\left[\begin{array}{lllll}
0 & 0 & 0 & 0 \\
0 & 0 & 0 & 0 & 0 \\
0 & 0 & 0 & 0
\end{array}\right]
$$

Carbonate-cemented breccia

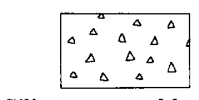

Silica-cemented breccia
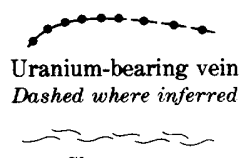

Shear zone
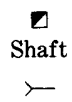

Adit

父

Prospect
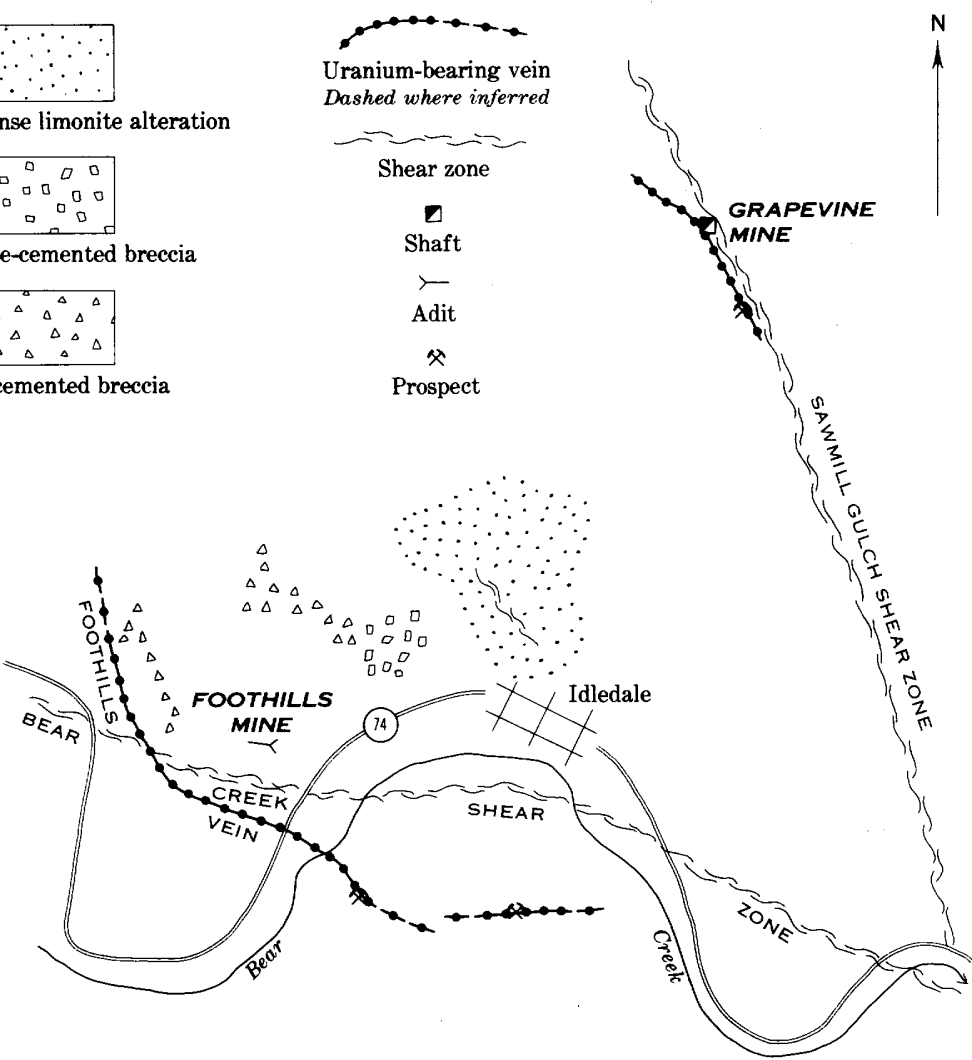

Country rock is Precambrian gneiss and schist

$1 / 2$ MILE

FIGURE 23.-Sketch map showing the geologic setting of the Idledale district, Jefferson County. Geology by J. D. Schlottmann, 1959.

district and roughly bound an area characterized by breccia and pervasive alteration (fig. 23). Two types of breccia have been distinguished by Schlottmann: (a) an earlier one that consists of variously sized angular fragments of granitic rock in a vuggy finegrained quartz matrix, and (b) a later one that consists of small fragments of relatively uniform size (including pieces of the early breccia) in a granular carbonate matrix. Rocks of the area are pervasively stained by limonite, particularly in a small area about midway between the two mines, as shown diagrammatically on figure 23. The faults that contain the ore deposits appear to be related to the major shear zones and probably resulted from relatively late movements along these shear zones. 
TABLE 9.-Uranium production from the Idledale district, Jefferson County, Colo., 1955-60

[Data compiled from records of U.S. Bur. Mines, Denver, Colo.; published with the permission of the mine owners]

\begin{tabular}{|c|c|c|c|c|}
\hline Mine & Year & $\begin{array}{c}\text { Crude ore } \\
\text { shipped } \\
\text { (short tons) }\end{array}$ & $\begin{array}{c}\text { Grade } \\
\text { (percent } \\
\mathrm{U}_{3} \mathrm{O}_{8}\end{array}$ & $\underset{\text { (pounds) }}{\mathrm{U}_{\mathbf{8}} \mathrm{O}_{\mathbf{g}}}$ \\
\hline \multirow{2}{*}{$\begin{array}{l}\text { Foothills. } \\
\text { Total } \\
\text { Average }\end{array}$} & $\begin{array}{l}1955 \\
1956 \\
1957 \\
1958 \\
1959\end{array}$ & $\begin{array}{r}9.42 \\
1,042.99 \\
1,011.42 \\
185 \\
1,670 \\
4,638\end{array}$ & $\begin{array}{r}0.26 \\
.35 \\
.30 \\
.30 \\
.23 \\
.24\end{array}$ & $\begin{array}{r}48.97 \\
7,212.66 \\
6,150.60 \\
1,110 \\
7,705 \\
22,064\end{array}$ \\
\hline & 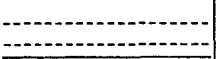 & $8,556.83$ & & $\begin{array}{r}44,291.23 \\
\end{array}$ \\
\hline \multirow{2}{*}{$\begin{array}{l}\text { Grapevine } 1 \text {. } \\
\text { Total } \\
\text { Average }\end{array}$} & $\begin{array}{l}1955 \ldots \\
1956 \\
1957 \\
1958 \\
1959\end{array}$ & $\begin{array}{c}11.80 \\
69.88 \\
0 \\
1,019 \\
527 \\
64\end{array}$ & $\begin{array}{r}0.33 \\
.28 \\
.47 \\
.21 \\
.15\end{array}$ & $\begin{array}{c}78.37 \\
384.59 \\
0 \\
9,631 \\
2,249 \\
186\end{array}$ \\
\hline & $\ldots$ & $1,691.68$ & & $12,528.96$ \\
\hline
\end{tabular}

1 Most of the production, 1955-60, was from the Grapevine mine, but the figures for 1955 and 1960 include a small amount from the Quatman lease.

\section{FOOTHILIS MINE}

\section{By J. D. SchlottmanN}

The Foothills mine, also known as the Wright lease, is in the southwestern part of the Idledale district, adjacent to Bear Creek (fig. 23). It has been the principal source of uranium ore in the district, and through 1960 had yielded more than 8,500 tons of crude ore that contained an average of 0.26 percent $\mathrm{U}_{3} \mathrm{O}_{8}$ (table 9 ).

The mine workings, shown on figure 24 , consist of a 475 -foot crosscut-adit, and an underground vertical shaft, and three levels, each of which contains stopes.

The mine workings are principally on the Foothills vein, which curves northwestward from N. $60^{\circ} \mathrm{W}$. to N. $20^{\circ} \mathrm{W}$. and dips $50^{\circ}-80^{\circ}$ NE. The vein is in quartz-biotite gneiss and granitic gneisses of the Mount Morrison Formation of Boos and Boos (1957). A breccia consisting of fragments of quartz-cemented breccia in a carbonate matrix forms the hanging wall of the vein in most of the mine workings. Rock fragments in the breccia are silicified and sericitized(?) and locally contain some hematite.

In detail, the Foothills vein is a curved compound fracture zone generally consisting of two or more anastamosing subparallel fissures (fig. 25). Cymoid loops and the pattern of branching suggest right lateral movement. The amount of displacement is unknown. The vein walls are sharply defined and commonly are slickensided. The vein is extremely vuggy and in places contains open vugs as much as 2 feet wide and 20 feet high. 


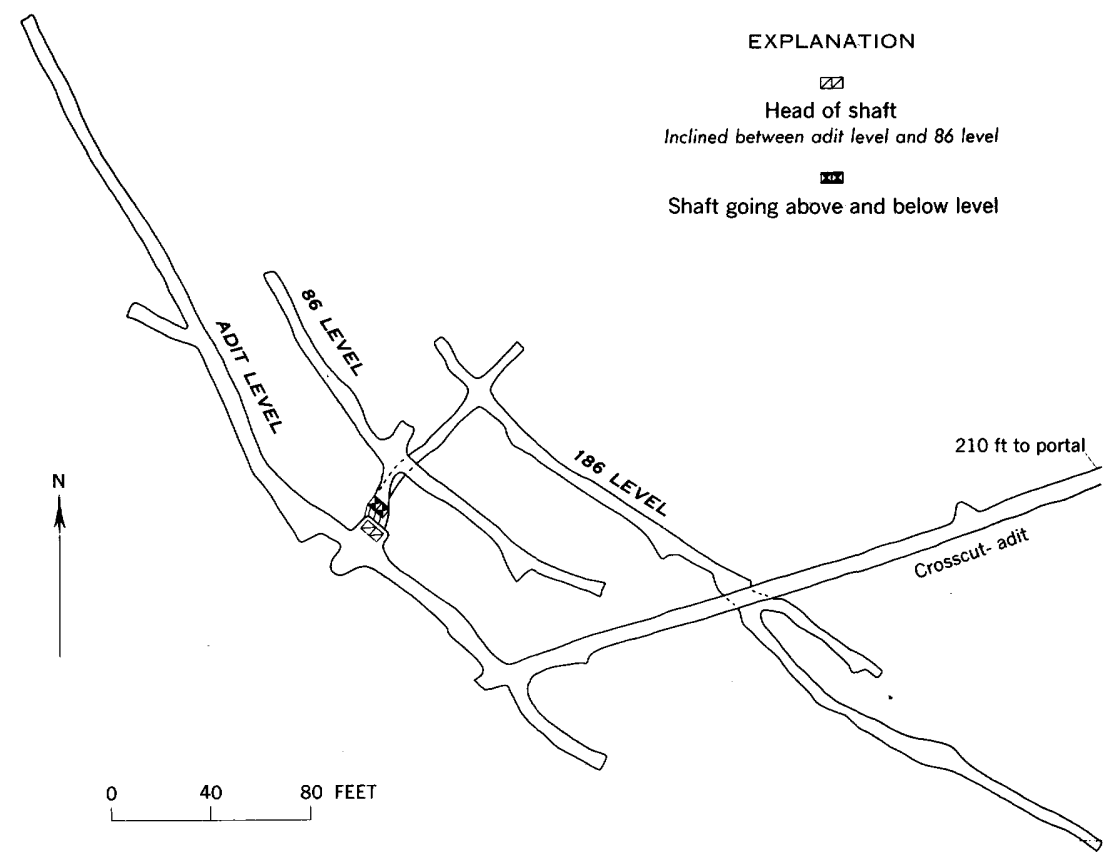

FiguRe 24.-Composite map showing mine workings, Foothills mine. Modified from company map, October 1959; published by permission.

The Foothills vein contains pitchblende, coffinite, pyrite, and sparse galena, chalcopyrite, marcasite, sphalerite, and tetrahedrite-tennantite(?) in a gangue of carbonate minerals, quartz, potassic feldspar, and chlorite. These minerals are products of two stages of mineralization. In the first stage, ankerite(?), pyrite, potassic feldspar, chlorite, and pitchblende were deposited and then were brecciated. In the second stage, coarse calcite, purple fluorite, and the sulfide ore minerals were deposited, and some pitchblende and potassic feldspar were replaced by calcite(?). Although some coffinite may have been deposited with the pitchblende of stage 1 , most of the coffinite occurs with sooty pitchblende as a coating on pyrite and gangue minerals in vugs, and apparently is a product of supergene solutions. Such coffinite and associated sooty pitchblende occur in a halolike zone surrounding fingerlike, limonite-rich oxidized zones, that extend from the surface at least to the 186-foot level. The ore halos lie 10-20 feet from the oxidized fingers and extend outward at least 50 or 60 feet. In them, chemical uranium exceeds radiometric equivalent uranium by a ratio of about $2.5: 1$, suggesting that the uranium minerals were deposited relatively recently. 


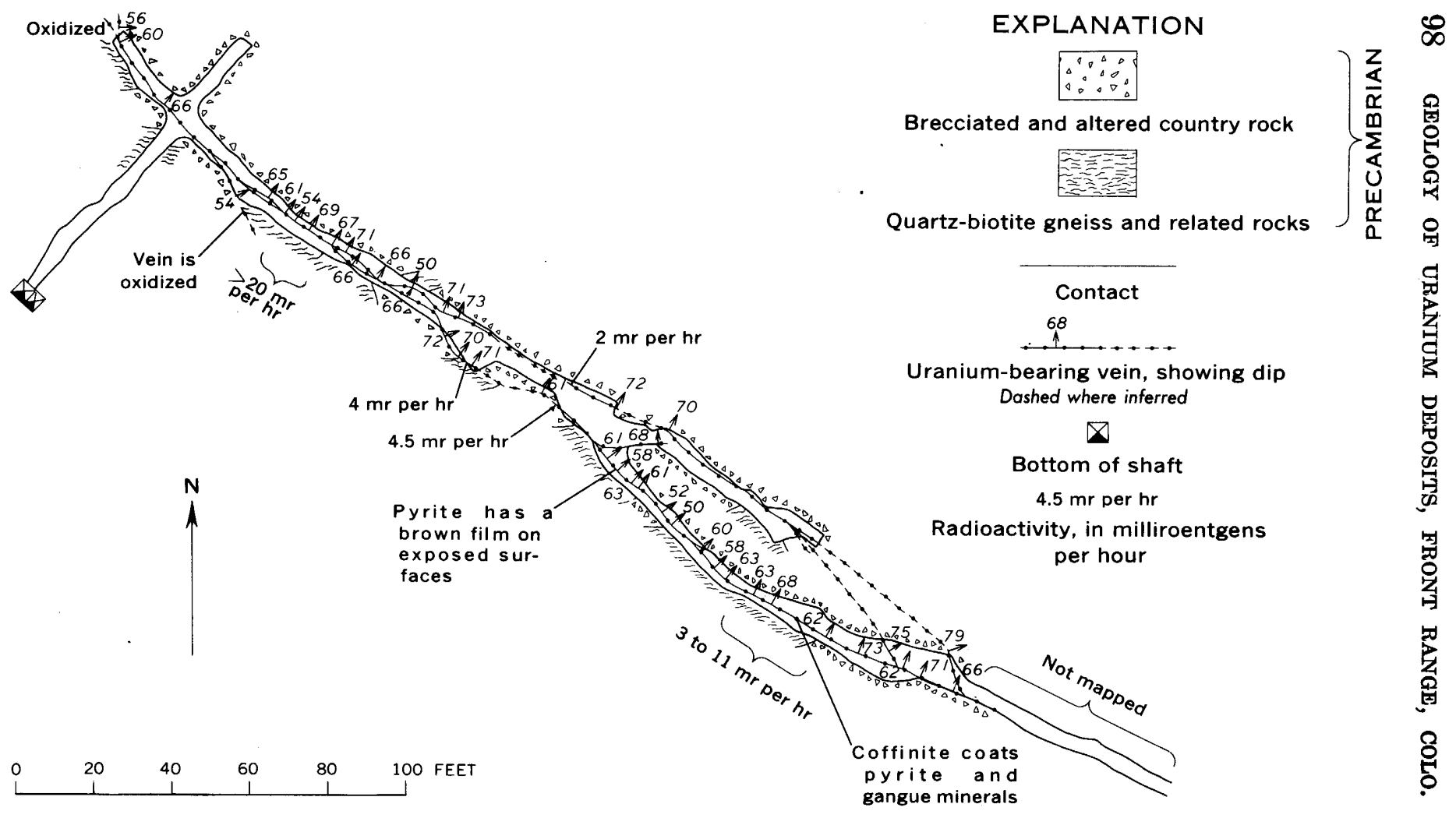

Figure 25.-Geologic map of 186-foot level, Foothills mine (Wright lease), Jefferson County. Geology by J. D. Schlottmann, 1959. Base modifled from company map, 1958; published by permission. 
The Grapevine mine is in Sawmill Gulch, northeast of the Foothills mine, at an altitude of 7,002 feet (fig. 23). Uranium was discovered on the property in 1955 when J. R. Wilson and Wayne Freedman found pitchblende in the streambed. An inclined shaft 55 feet deep was then sunk, and 77 tons of ore that contained an average of 0.29 percent $\mathrm{U}_{3} \mathrm{O}_{8}$ was extracted, largely from a level at a depth of 30 feet. From 1956 to 1958, four core drill holes were completed, a new (main) vertical shaft was sunk at a site about 350 feet north of the inclined shaft, and about 425 feet of crosscuts and drifts were driven from the shaft at the 92-foot level (fig. 26). A substantial part of this work was done with the assistance of an exploration contract with the Defense Minerals Exploration Administration. From 1955 through 1960, $1,691.68$ tons of ore containing an average of about 0.37 percent $\mathrm{U}_{3} \mathrm{O}_{8}$ was shipped from the mine (table 9).

The mine is in an area of mixed gneisses that in general strike northwestward and dip northeastward. Biotite-quartz gneiss predominates within the mine and is silicified adjacent to the veins and faults.

The mine workings are principally on veins that strike northwest and dip $20^{\circ}-60^{\circ} \mathrm{NE}$. (fig. 26). Most of the ore has been obtained from the East vein and from a flat-dipping branch vein in its footwall, southeast of the shaft. A vein found 50 feet west of the shaft is presumably the Target vein - the vein on which the original inclined shaft was sunk. Both the East and the Target(?) veins appear to be branch faults in the footwall of a strong fault of west-northwest strike exposed in the northwestern part of the mine, although it is perhaps possible that this fault turns and becomes continuous with the East vein (fig. 26).

The uranium ore occurs in lenticular bodies 1-2 feet wide within the veins. In these bodies, pitchblende coats fractures and altered rock fragments in breccia that also contains pyrite, quartz, feldspar, and clay minerals.

\section{OTHER AREAS}

A few other deposits, generally of lesser importance than those of the Ralston Buttes and Idledale districts, are scattered through Jefferson County, as shown in figure 2. Most of these are in the Precambrian terrane, and one of them is described below. Three noteworthy deposits in the sedimentary rocks of the foothills are described also. 


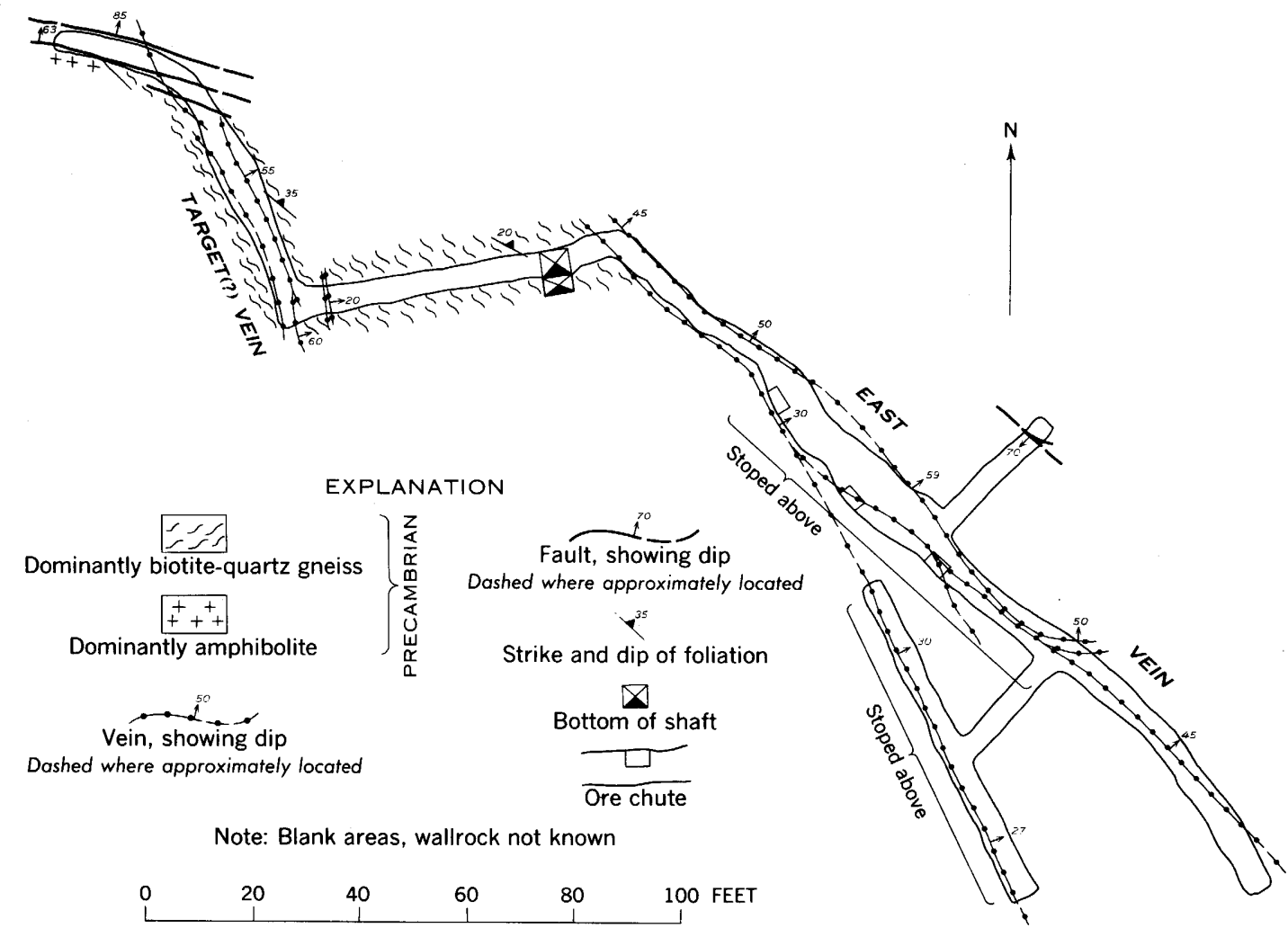

FIGURE 26.-Geologic sketch map of the Grapevine mine, Jeffer: on County. Geology compiled by R. U. King from company maps, 1958. Published by permission. 
By F. B. MOore

The Black Knight and Billikin lodes are about 3 miles southwest of Critchell (fig. 2), on the northeast side of Kennedy Gulch, at altitudes ranging from about 8,100 to 8,300 feet. The lodes were prospected for copper, gold, and silver before the turn of the century. In 1955, C. V. Haynes, Jr., and G. A. Boyd, Jr., discovered secondary uranium minerals in shallow pits. Subsequently, the uranium showings were explored by means of diamond-core drilling and a 55-foot shaft inclined $70^{\circ} \mathrm{NE}$ and by core holes totaling 1,646 feet drilled with the assistance of an exploration contract from the Defense Minerals Exploration Administration in 1957 and 1958. Small quantities of uranium were found, but not enough to support mining, and no ore was produced.

The uranium is scattered in local pockets along two faults, the Billikin and the Black Knight, which transect Precambrian metamorphic and granitic rocks. The principal rocks are biotite gneiss, amphibolite, and granite gneiss and pegmatite in a layered conformable sequence that strikes about $\mathrm{N} .70^{\circ} \mathrm{W}$. and dips $50^{\circ}-60^{\circ} \mathrm{NE}$. The biotite gneiss encloses a 5- to 60-foot layer of magnetite-rich garnet gneiss. The Black Knight fault, which is related to the breccia reef faults, strikes about $\mathrm{N} .70^{\circ} \mathrm{W}$. and dips $50^{\circ}-60^{\circ} \mathrm{NE}$., subparallel to the strike and dip of the country rock. It is marked by thin subparallel fractures and by streaks of breccia in a zone 3-5 feet and contains carbonate minerals, pitchblende, and sparse pyrite, chalcopyrite, and bornite. In places along its outcrop, it contains secondary uranium minerals, including becquerelite and probably autunite and torbernite. The fault has been traced about 900 feet along strike. The Billikin fault, also a breccia zone, strikes north-northeastward, dips $50^{\circ}-70^{\circ} \mathrm{E}$. and presumably intersects the Black Knight fault of the mine area. It is several feet wide and contains some secondary copper and uranium minerals at the surface.

Primary uranium appears to be confined to places where the Black Knight fault intersects the magnetite-bearing garnet gneiss layer. The pitchblende fills thin fractures and has a colloform texture. It was the first metallic mineral deposited and was brecciated before chalcopyrite and bornite were deposited (Caleb Haynes, Jr., written communication, 1958). 


\section{FOUR CORNERS ORANIUM MINE}

By D. H. RIChter

The Four Corners uranium mine, also known as the Pallaoro lease or the Morrison mine, lies about $1 \frac{11}{2}$ miles east of the Precambrian core of the Front Range, on the east slope of the prominent hogback north of Turkey Creek, about 11/2 miles southeast of Morrison (pl. 5). The uranium deposit worked in the mine is at the intersection of a persistent fault, the Damming fault, and the upper sandstone of the Dakota Group of Early Cretaceous age. A similar deposit, also along the Damming fault, was worked in the Mann No. 1 mine, about 500 feet to the southeast. The geology of the area has been described by Goldstein (1957).

Uranium was discovered in the Four Corners mine area in 1954 by S. N. and R. W. Stauss. During the following winter the area was explored by drilling, and at the same time, a 75 -foot vertical shaft was sunk and about 310 feet of drifting and stoping were done. In 1958, further drilling was done along the Damming fault northwest of the mine, largely under a Defense Minerals Exploration Administration exploration contract. This drilling revealed uranium ore in places along the fault for a distance of 800 feet from the shaft. The total production from the property through 1960 was 699.13 tons of ore that contained an average of 0.19 percent $\mathrm{U}_{3} \mathrm{O}_{8}$ (table 10 ).

TABLE 10.-Uranium production from the Four Corners and Mann No. 1 mines, Jefferson County, Colo., 1955-60

[Data compiled from records of U.S. Bur. Mines, Denver, Colo.; published with the permission of the mine owners]

\begin{tabular}{|c|c|c|c|c|}
\hline Mine & Year & $\begin{array}{c}\text { Crude ore } \\
\text { shipped } \\
\text { (short tons) }\end{array}$ & $\begin{array}{c}\text { Grade } \\
\text { (percent } \\
\mathrm{U}_{3} \mathrm{O}_{8} \text { ) }\end{array}$ & $\begin{array}{c}\mathrm{U}_{3} \mathrm{O}_{8} \\
\text { (pounds) }\end{array}$ \\
\hline Four Corners (Morrison) & $\begin{array}{l}1955 \\
1956 \\
1957 \\
1958 \\
1959\end{array}$ & $\begin{array}{c}353.77 \\
262.46 \\
61.90 \\
0 \\
0 \\
21\end{array}$ & $\begin{array}{r}0.19 \\
.20 \\
.23 \\
.08\end{array}$ & $\begin{array}{c}1,328 \\
1,054.63 \\
284.69 \\
0 \\
0 \\
34\end{array}$ \\
\hline $\begin{array}{l}\text { Total } \\
\text { Average }\end{array}$ & 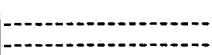 & 699.13 & .19 & $\begin{array}{r}2,701.32 \\
-\end{array}$ \\
\hline Mann No. 1........ & $\begin{array}{l}1955 \\
1956 \\
1957 \\
1958 \\
1969 \\
1960\end{array}$ & $\begin{array}{r}6.17 \\
1,022.78 \\
404.12 \\
1,320 \\
75 \\
43\end{array}$ & $\begin{array}{l}0.21 \\
.30 \\
.36 \\
.21 \\
.14 \\
.17\end{array}$ & $\begin{array}{l}25.92 \\
6,088.72 \\
2,907.72 \\
5,672 \\
205 \\
150\end{array}$ \\
\hline $\begin{array}{l}\text { Total } \\
\text { Average. }\end{array}$ & $-\ldots$ & $2,871.07$ & .26 & $15,049.36$ \\
\hline
\end{tabular}


The mine workings consist of a 75-foot shaft and two levels at depths of 62 and 75 feet. In 1958, the 75-foot level extended about 200 feet northwest from the shaft and about 100 feet to the southwest. All the workings are in the upper sandstone of the Dakota Group, above a shale unit. The rocks of the Dakota Group strike about N. $40^{\circ} \mathrm{W}$. and $\operatorname{dip} 25^{\circ}-30^{\circ} \mathrm{NE}$.

The principal structural feature in the mine area is the Damming fault, which strikes $\mathrm{N}$. $40^{\circ}$ W., subparallel to the strike of the sedimentary units, and dips $50^{\circ}-55^{\circ} \mathrm{SW}$. The fault has been traced about a thousand feet along strike (pl. 5) and it probably extends much farther, at least to the northwest, where its projected trend is marked by a line of radioactive springs extending 3,600 feet from the mine. The apparent movement on the fault is dominantly strike slip. At the mine, the fault ranges in width from a 1-inch fracture to a 3-foot zone of subparallel fractures.

The uranium ore occurs in the lower part of the upper sandstone of the Dakota Group, in and adjacent to the Damming fault (pl. 5). It is in elongated, thin, discontinuous ore bodies that parallel the intersection of the fault and bedding. The ore bodies are as much as 60 feet long and range in thickness (measured across bedding) from 1 to about 20 feet. The width of the bodies is variable, but ore generally does not extend more than 20 feet updip or downdip from the fault. Most of the ore mined has come from the hanging wall of the fault, although the cross section on plate 5 shows a locality where the ore was in the footwall.

The uranium of the ore bodies is in the form of uraninite and uraniferous asphalt, which are associated with pyrite and ilsemannite(?). In places, the fault contains lenses of massive gray to grayish-brown quartz, 2-6 inches thick; the quartz generally has a banded structure outlined by layers of pure and pyritic quartz. The uranium and other vein minerals coat grains and fill interstices in the sandstone and to a small extent fill fractures in the fault zone. Some of the ore material is in "bubblelike" spheroids made up of concentric bands of uraninite surrounding a grain of pyrite. Although selected material may contain 1 or 2 percent $\mathrm{U}_{3} \mathrm{O}_{8}$, the average grade of the deposits is about 0.20 percent $\mathrm{U}_{3} \mathrm{O}_{8}$.

Ore in the Four Corners mine is restricted to a particular stratigraphic zone and to the near vicinity of the Damming fault, and the combination of these two factors clearly accounts for its localization. The ore-forming solutions apparently rose along the fault to the sandstone zone made favorable by its permeability, and there deposited their uranium. 
MANN NO. 1 MrNE

By D. H. Richter

The Mann No. 1, or J. L. Mann, mine is about 590 feet southeast of the Four Corners mine on the south side of Turkey Creek (pl. 5). The geology and ore occurrences of the mine have been described by Goldstein (1957) and are nearly identical with those of the Four Corners mine.

The deposit was first explored by means of a 50-foot tunnel on the lower west or steep slope of the eastward-dipping hogback on the south side of Turkey Creek. Uraninite was found in this tunnel, and 6 tons of ore containing 0.21 percent $\mathrm{U}_{3} \mathrm{O}_{8}$ was shipped. During subsequent core drilling on the east or dip slope side of the hogback, uraninite ore was found in the lower part of the upper sandstone of the Dakota Group, adjacent to the Damming fault. A tunnel and drift were then driven to reach this ore (pl. 5). In 1956 and 1957 additional drilling was done in conjunction with the Defense Minerals Exploration Administration. The total production from the property through 1960 was $2,871.07$ tons of ore that contained an average of about 0.26 percent $\mathrm{U}_{3} \mathrm{O}_{8}$ (table 10 ).

The ore bodies are in the upper sandstone of the Dakota Group (section $B-B^{\prime}$, pl. 5), immediately above the shale unit and adjacent to the Damming fault. In contrast to the Four Corners uranium mine, however, nearly all the ore is in the footwall of the fault. The deposits are elongate parallel to the fault and wedge shape in cross section, thinning and pinching out downdip along the bedding. According to Goldstein (1957, p. 781), ore extends downdip along the bedding for distances from 10 to 30 feet from the fault plane; both the dimensions and grade of the ore decrease upward along the fault plane.

Goldstein (1957, p. 781-784) presented persuasive evidence that the uranium is of primary origin and that it was precipitated from ascending hydrothermal solutions that rose along the Damming fault.

\section{OLD IEYDEN COAL MINE}

Uranium deposits in the Old Leyden coal mine are of interest because the uranium is in coal and adjoining sandstone in the Laramie Formation of Late Cretaceous age. The deposit lies about 2 miles east of the mountain front but is presumed to be related genetically to the vein deposits within the Front Range. The mine was studied by the U.S. Geological Survey during the early 1950's (Gude and McKeown, 1953). Total production through April 1956 was 645.37 tons of ore that contained an average of about 0.35 percent $\mathrm{U}_{3} \mathrm{O}_{8}$.

The Old Leyden coal mine (19, fig. 2$)$ is on a ridge, known locally as Leyden Ridge, excavated out of the high-plains surface by Leyden Gulch, about 6 miles north of Golden. The workings consist of a 
330-foot crosscut adit, the portal of which is on the west side of the ridge at an altitude of 5,900 feet, and of a 184-foot vertical shaft and several opencuts and short adits. The shaft, sunk with the financial assistance of the Defense Minerals Exploration Administration, is on the east side of the ridge at an altitude of about 5,925 feet. A level at a depth of 175 feet extends 440 feet north and 70 feet south from the shaft.

Uranium was discovered in the mine in 1874 (Berthoud, 1875), but none was mined until 1950, when a few tons of silicified ore that contained about 0.18 percent $\mathrm{U}_{3} \mathrm{O}_{3}$ was extracted from the east end of the adit. Subsequently, the area was explored by core drilling, first by the mining company and later by the U.S. Bureau of Mines on behalf of the U.S. Atomic Energy Commission. The government drilling indicated the presence of enough uranium-bearing material to warrant further exploration. In 1952, under contract with the Defense Minerals Exploration Administration, the vertical shaft was sunk, the 175-foot level was driven, and an 88-foot raise was driven from a point about 335 feet north of the shaft. This work disclosed a small quantity of uranium ore, but very little additional mining was done before the mine was closed in 1954 .

The geology of the mine area has been described by Gude and McKeown (1953); for the regional geologic setting the reader is referred to the geologic map of the Golden quadrangle (Van Horn, 1957).

The uranium-bearing coal and associated strata at the Old Leyden coal mine are in the lower part of the Laramie Formation, approximately 170 feet above the top of the underlying Fox Hills Sandstone. In the mine area, these strata strike about N. $4^{\circ}$ E., and the dip ranges from about $60^{\circ} \mathrm{E}$. through vertical to an overturned dip of $75^{\circ}$ W. Many bedding-plane and low-angle reverse faults are present.

The uranium occurs in a brecciated and silicified coal bed and associated carbonaceous claystone, and also in silicified sandstone that overlies the coal bed. It appears to be localized in intensely fractured areas that are related in origin to steep faults subparallel to the bedding. Metatyuyamunite is the principal uranium mineral but autunite, uranophane, and coffinite have been identified also. The uranium minerals occur in fractures in the brecciated coal and claystone and as coatings around sand grains and on fracture surfaces in the overlying sandstone. Sparse pyrite and marcasite occur with the uranium.

The uranium occurs within a poorly defined, steeply plunging shoot that is possibly as much as 80 feet in strike length and extends from the surface nearly to the 175 -foot level of the main shaft, a maximum vertical distance of about 300 feet. 


\section{LITERATURE CITED}

Adams, J. W., Gude, A. J., 3d, and Beroni, E. P., 1953, Uranium occurrences in the Golden Gate Canyon and Ralston Creek areas, Jefferson County, Colorado: U.S. Geol. Survey Circ. 320,16 p.

Adams, J. W., and Stugard, Frederick, Jr., 1956a, Wall-rock control of certain pitchblende deposits in Golden Gate Canyon, Jefferson County, Colorado, in Page, Stocking, and Smith, compilers: U.S. Geol. Survey Prof. Paper 300, p. 113-116.

- 1956b, Wallrock control of certain pitchblende deposits in Golden Gate Canyon, Jefferson County, Colorado, in Geology of uranium and thorium: United Nations, New York, Proc. Internat. Conf. Peaceful Uses Atomie Energy, 1955, v. 6, paper 24, p. 279-282.

- 1956c, Wallrock control of certain pitchblende deposits in Golden Gate Canyon, Jefferson County, Colorado: U.S. Geol. Survey Bull. 1030-G, p. 187-209.

Alsdorf, P. R., 1916, Occurrence, geology, and economic value of the pitchblende deposits of Gilpin County, Colorado: Econ. Geology, v. 11, p. 266-275.

Armstrong, F. C., 1952, Pitchblende deposits on Quartz Hill, Central City district, Gilpin County, Colorado [abs.]: Geol. Soc. America Bull., v. 63, no. 12 , pt. 2 , p. 1232.

Barton, P. B., Jr., 1956, Fixation of uranium in the oxidized base metal ores of the Goodsprings district, Clark County, Nevada: Econ. Geology, v. 51, no. 2, p. 178-191.

Bastin, E. S., 1915, Geology of the pitchblende ores of Colorado: U.S. Geol. Survey Prof. Paper 90-A, p. 1-5.

1916, Discussion. Occurrence, geology, and economic value of the pitchblende deposits of Gilpin County, Colorado: Econ. Geology, v. 11, p. 681-685.

1950, Interpretation of ore textures: Geol. Soc. America Mem. 45, $101 \mathrm{p}$.

Bastin, E. S., and Hill, J. M., 1917, Economic geology of Gilpin County and adjacent parts of Clear Creek and Boulder Counties, Colorado. U.S. Geol. Survey Prof. Paper 94, 379 p.

Berthoud, E. L., 1875, On the occurrence of uranium, silver, iron, etc., in the Tertiary formation of Colorado Territory: Acad. Nat. Sci. Philadelphia Proc., v. 27, pt. 2, p. 363-366.

Bird, A. G., 1956, Primary pitchblende deposits at the Ralston Creek mine [Colo.]: Uranium and Modern Mining, v. 3, no. 8, p. 8, 44.

- 1957a, Uranium deposits in Golden Gate Canyon and Ralston Creek area of Jefferson County, Colorado: Mines Mag., v. 47, no. 3, p. 91-93.

- 1957b, Pitchblende occurrences in the Golden Gate Canyon-Ralston Creek areas of Jefferson County, Colorado [abs.]: Geol. Soc. America Bull., v. 68 , p. $1858-1859$.

Bird, A. G., and Stafford, H. S., 1955, Uranium deposits of the Colorado Front Range foothills region: Mines Mag., v. 45, no. 3, p. 81-82.

Boos, C. M., and Boos, M. F., 1957, Tectonics of eastern flank and foothills of Front Range, Colorado: Am. Assoc. Petroleum Geologists Bull., v. 41, no. 12 , p. 2603-2676.

Brooker, E. J., and Nuffield, E. W., 1952, Pitchblende from Lake Athabaska, Canada, pt. 4 of Studies of radioactive compounds: Am. Mineralogist, v. 37 , nos. 5-6, p. 363-385. 
Campbell, R. H., 1955, Reoonnaissance for radioactivity in the Gold Hill mining area, Boulder County, Colorado: U.S. Geol. Survey TEM- 563-A, issued by U.S. Atomic Energy Comm. Tech. Inf. Service, Oak Ridge, Tennessee.

Del Rio, S. M., ed., 1960, Mineral Resources of Colorado; first sequel: Denver, Colo., Publishers Press.

Drake, A. A., Jr., 1957, Geology of the Wood and East Calhoun mines, Central City district, Gilpin County, Colorado: U.S. Geol. Survey Bull. 1032-C, p. $129-170$.

Everhart, D. L., and Wright, R. J., 1953, The geologic character of typical pitchblende veins: Econ. Geology, v. 48, no. 2, p. 77-96.

Faul, Henry, ed., and others, 1954, Nuclear geology-a symposium on nuclear phenomena in the earth sciences: New York, John Wiley and Sons, Inc., $414 \mathrm{p}$.

Frondel, Clifford, 1958, Systematic mineralogy of uranium and thorium: U.S. Geol. Survey Bull. 1064, 400 p.

Garrels, R. M., and Christ, C. L., 1959, Behavior of uranium minerals during oxidation, in Garrels, R. M., and Larsen, E. S., 3d, Geochemistry and mineralogy of the Colorado Plateau uranium ores: U.S. Geol. Survey Prof. Paper 320, p. 81-89.

Geffroy, Jacques, and Sarcia, J. A., 1954, Contribution à l'étude des pechblendes françaises: L'Université de Nancy, Annales de l'Ecole Natl. Supér. de Géologic Appl. et de Prospect. Minière, Sci. de la Terre, v. 2, nos. 1-2, 157 p.

Goddard, E. N., 1940, Preliminary report on the Gold Hill mining district, Boulder County, Colorado: Colorado Sci. Soc. Proc., v. 14, no. 4, p. 103-139.

- 1946, Fluorspar deposits of the Jamestown district,-Boulder County, Colorado: Colorado Sci. Soc. Proc., v. 15, no. 1, p. 1-47.

Goddard, E. N., and Glass, J. J., 1940, Deposits of radioactive cerite near Jamestown; Colorado: Am. Mineralogist, v. 25, no. 6, p. 381-404.

Goldstein, E. H., 1957, Geology of the Dakota formation uraninite deposit near Morrison, Colorado: Econ. Geology, v. 52, no. 7, p. 775-785.

Gritsaenko, G. S., Belova, L. N., Getseva, R. V., and Savelyeva, K. T., 1958, Mineralogical types of oxidation zones of hydrothermal uranium and sulphide-uranium ores of the USSR, in Proc. 2d United Nations Internat. Conf. on Peaceful Uses of Atomic Energy, b. 2, Survey of Raw Material Resources, p. 466-474.

Gude, A. J., 3d, and McKeown, F. A., 1953, Results of exploration at the Old Leyden coal mine; Jefferson County, Colorado: U.S. Geol. Survey openfile rept.

Harrison, J. A., 1955, Petrographic components and stoker coal testing [abs.]: Econ. Geology, v. 50, no. 7, p. 778; Geol. Soc. America Bull., v. 66, no. 12, pt. 2, p. 1752.

Harrison, J. E., and Leonard, B. F., 3d, 1952, Preliminary report on the Jo Reynolds area, Lawson-Dumont district, Clear Creek County, Colorado: U.S. Geol. Survey Circ. 213, 9 p.

Harrison, J. E., and Wells, J. D., 1956, Geology and ore deposits of the FreelandLamartine district, Clear Creek County, Colorado: U.S. Geol. Survey Bull. 1032-B, p. 33-127.

1959, Geology and ore deposits of the Chicago Creek area, Clear Creek County, Colorado: U.S. Geol. Survey Prof. Paper 319, 92 p.

Hawley, C. C., and Moore, F. B., 1955, Control of uranium deposition by garnetquartz rock in the Fall River area, Clear Creek County, Colorado [abs.]: Geol. Soc. America Bull., v. 66, no. 12, pt. 2, p. 1675. 
Hillebrand, W. F., 1891, On the occurrence of nitrogen in uraninite and on the composition of uraninite in general: U.S. Geol. Survey Bull 78, p. 43-79.

Holmes, Arthur, 1947, The construction of a geological time-scale: Geol. Soc. Glasgow Trans., v. 21. pt. 1, p. 117-152.

- 1959, A revised geological time-scale: Edinburgh Geol. Soc. Trans., v. 17, pt. 3, p. 183-216.

Kidd, D. F., and Haycock, M. H., 1935, Mineragraphy of the ores of Great Bear Lake: Geol. Soc. America Bull., v. 46, no. 6, p. 879-960.

King, R. U., Leonard, B. F., Moore, F. B., and Pierson, C. T., 1953, Uranium in the metal-mining districts of Colorado: U.S. Geol. Survey Circ., 215, 10 p.

Lang, A. H., 1952, Canadian deposits of uranium and thorium (interim account): Canada Geol. Survey Econ. Geology ser.-16, 173 p.

Larsen, E. S., Jr., and Phair, George, 1954, The distribution of uranium and thorium in igneous rocks, in Faul, Henry, and others, Nuclear geology, p. 75-88, New York, John Wiley and Sons.

Lee, W. T., 1927, Correlation of geologic formations between east-central Colorado, central Wyoming, and southern Montana: U.S. Geol. Survey Prof. Paper 149, $80 \mathrm{p}$.

Leonard, B. F., 3d, 1952, Relation of pitchblende deposits to hypogene zoning in the Front Range mineral belt, Colorado [abs.]: Geol. Soc. America Bull., v. 63 , no. 12 , pt. 2 , p. $1274-1275$.

Lindgren, Waldemar, 1933, Mineral deposits: 4th ed., New York, McGraw-Hill Book Co., 930 p.

Lovering, T. G., 1955, Progress in radioactive iron oxides investigations: Econ. Geology, v. 50, no. 2, p. 186-195.

Lovering, T. S., 1934, Geology and ore deposits of the Breckenridge mining district, Colorado: U.S. Geol Survey Prof. Paper 176, 64 p.

- 1942, The mineral belt of the Colorado Front Range, in Newhouse, W. H., ed., Ore deposits as related to structural features: Princeton Univ. Press, p. 79-93.

Lovering, T. S., and Goddard, E. N., 1938, Laramide igneous sequence and differentiation in the Front Range, Colorado: Geol. Soc. America Bull., v. 49, no. 1 , p. $35-68$.

1950, Geology and ore deposits of the Front Range, Colorado: U.S. Geol. Survey Prof. Paper 223, 319 p.

Lovering, T. S., and Tweto, Ogden, 1953, Geology and ore deposits of the Boulder County tungsten district, Colorado: U.S. Geol. Survey Prof. Paper 245, $199 \mathrm{p}$.

McKelvey, V. E., Everhart, D. L., and Garrels, R. M., 1955, Origin of uraniu m deposits: Econ. Geology, Fiftieth Anniversary Volume, 1905-55, pt. 1, p. 464-533.

Mining and Science Press, 1884, v. 48, no. 11, p. 195.

Moench, R. H., Harrison, J. E., and Sims, P. K., 1962, Precambrian folding in the Idaho Springs-Central City area, Front Range, Colorado: Geol. Soc. America Bull., v. 73, p. 35-58.

Moore, F. B., and Butler, C. R., 1952, Pitchblende deposits at the Wood and Calhoun mines, Central City mining district, Gilpin County, Colorado: U.S. Geol. Survey Circ. 186, 8 p.

Moore, F. B., Cavender, W. S., and Kaiser, E. P., 1957, Geology and uranium deposits of the Caribou area, Boulder County, Colorado: U.S. Geol. Survey Bull. 1030-N, p. 517-552. 
Moore, R. B., and Kithil, K. L., 1913, A preliminary report on uranium, radium, and vanadium: U.S. Bur. Mines Bull. 70, Mineralog. Technology 2, p. 43-47.

Myers, A. T., Havens, R. G., and Dunton, P. J., 1961, A spectrochemical method for the semiquantitative analysis of rocks, minerals, and ores: U.S. Geol. Survey Bull. 1084-I, p. 207-229.

Nininger, R. D., 1954, Minerals for atomic energy - a guide to exploration for uranium, thorium, and beryllium: New York, Van Nostrand Co., 367 p.

Page, L. R., 1950, Uranium in pegmatites: Econ. Geology, v. 45, no. 1, p. 12-34.

Palache, Charles, Berman, Harry, and Frondel, Clifford, 1944, System of mineralogy of James Dwight Dana and Edward Salisbury Dana: 7th ed., New York, John Wiley and Sons, v. 1.

Pearce, Richard, 1898, Some notes on the occurrence of uraninite in Colorado: Colorado Sci. Soc. Proc., v. 5, p. 156-158.

Phair, George, 1952, Radioactive Tertiary porphyries in the Central City district, Colorado, and their bearing upon pitchblende deposition: U.S. Geol. Survey TEI-247, issued by U.S. Atomic Energy Comm. Tech. Inf. Service, Oak Ridge, Tenn.

Phair, George, and Levine, Harry, 1953, Notes on the differential leaching of uranium, radium, and lead from pitchblende in $\mathrm{H}_{2} \mathrm{SO}_{4}$ solutions: Econ. Geology, v.. 48, no. 2, p. 358-369.

Phair, George, and Shimamoto, K. O., 1952, Hydrothermal uranothorite in fluorite breccias from the Blue Jay mine, Jamestown, Boulder County, Colorado: Am. Mineralogist, v. 37, nos. 7-8, p. 659-666.

Ramdohr, Paul, 1955, Die Erzmineralien und ihre -Verwachsungen: 2d ed., Berlin, Akademie-Verlag., 875 p.

Rickard, Forbes, 1913, Pitchblende from Quartz Hill, Gilpin County, Colorado: San Francisco, Calif. Mining and Sci. Press, v. 106, no. 23, p. 851-856.

Robinson, S. C., 1955, Mineralogy of úranium deposits, Goldfields, Saskatchewan: Canada Geol. Survey Bull. 31, 128 p.

Sheridan, D. M., 1956, Ralston Buttes, Colorado, in Geologic investigations of radioactive deposits-semiannual progress report for June 1 to November 30, 1956: U.S. Geol. Survey TEI-640, issued by U.S. Atomic Energy Comm. Tech. Inf. Service, Oak Ridge, Tenn., p. 125-137.

Sheridan, D. M., Maxwell, C. H., Albee, A. L., and.Van Horn, Richard, 1958, Preliminary map of bedrock geology of the Ralston Buttes quadrangle, Jefferson County, Colorado: U.S. Geol. Survey Mineral Inv. Field Studies Map MF-179.

Sims, P. K., 1956a, Paragenesis and structure of pitchblende-bearing veins, Central City district, Gilpin County, Colorado: Econ. Geology, v. 51, no. 8, p. $739-756$.

1956b, Uranium deposits in the Front Range, Colorado: Mines Mag., v. 46, no. 3, p. 77-79.

1960, Geology of the Central City-Idaho Springs area, Front Range, Colorado, in Weimer, R. J., and Haun, J. D., eds., Guide to the geology of Colorado: Geol. Soc. America, Rocky Mtn. Assoc. Geologists, Colorado Sci. Soc., p. 279-285.

Sims, P. K., and Barton, P. B., Jr., 1961, Some aspects of the geochemistry of sphalerite, Central City district, Colorado: Econ. Geology, v. 56, no. 7, p. 1211-1237.

1962, Hypogene zoning and ore genesis, Central City district, Colorado:

Geol. Soc. Ameriea, Buddington volume, p. 373-396. 
Sims, P. K., Drake, A. A., Jr., and Tooker, E. W., 1963, Economic geology of the Central City district, Gilpin County, Colorado: U.S. Geol. Survey Prof. Paper 359.

Sims, P. K., Osterwald, F. W., and Tooker, E. W., 1955, Uranium deposits in the Eureka Gulch area, Central City district, Gilpin County, Colorado: U.S. Geol. Survey Bull. 1032-A, p. 1-31.

Sims, P. K., and others, 1963, Geology of uranium and associated ore deposits, central part of the Front Range mineral belt, Colorado: U.S. Geol. Survey Prof. Paper 371.

Sims, P. K., Phair, George, and Moench, R. H., 1958, Geology of the Copper King uranium mine, Larimer County, Colorado: U.S. Geol. Survey Bull. 1032-D, p. 171-221.

Sims, P. K., and Tooker, E. W., 1956, Pitchblende deposits in the Central City district and adjoining areas, Gilpin and Clear Creek Counties, Colorado, in Geology of uranium and thorium: United Nations, New York, Proc. Internat. Conf. on Peaceful Uses of Atomic Energy, 1955, v. 6, p. 265-269; also in Page, Stocking, and Smith, compilers: U.S. Geol. Survey Prof. Paper 300, p. 105-111.

Sims, P. K., Young, E. J., and Sharp, W. N., 1961, Coffinite in uranium vein deposits of the Front Range, Colorado, in Short papers in the geologic and hydrologic sciences: U.S. Geol. Survey Prof. Paper 424-B, part 2, p. B3-B5.

Spurr, J. E., and Garrey, G. H., 1908, Economic geology of the Georgetown quadrangle (together with the Empire district), Colorado, with general geology by S. H. Ball: U.S. Geol. Survey Prof. Paper 63, 422 p.

Stieff, L. R., Stern, T. W., and Sherwood, A. M., 1956, Coffinite, a uranous silicate with hydroxl substitution-a new mineral: Am. Mineralogist, v. 41, nos. 9-10, p. 675-688.

Stugard, Frederick, Jr., Wyant, D.G., and Gude, A.J., 3d, 1952, Secondary uranium deposits in the United States, in Selected papers on uranium deposits in the United States: U.S. Geol. Survey Circ. 220, p. 19-25.

Tishkin, A. I., Tananayeva, G. A., Gladishev, G. D., Melnikov, I. V., Polikarpova, V. A., and Tsibulskaya, M. S., 1958, Paragenetic associations of hydrothermal uranium minerals in uranium deposits of the Soviet Union, in Proc. 2d United Nations Internat. Conf. on Peaceful Uses of Atomic Energy, v. 2, Survey of Raw Material Resources, p. 445-465.

Tooker, E. W., 1956, Alter ed wall rocks along vein deposits in the Central CityIdaho Springs region, Colorado, in Swineford, Ada, ed., Clays and clay minerals, Natl. Research Council Pub. 456, p. 348-361.

Tweto, Ogden, 1960, Scheelite in the Precambrian gneisses of Colorado: Econ. Geology, v. 55, no. 7, p. 1406-1428.

Tweto, Ogden, and Sims, P. K., 1963, Precambrian ancestry of the Colorado Mineral Belt: Geol. Soc. America Bull., v. 74, no. 8, p. 991-1014.

Van Horn, Richard, 1957, Bedrock geology of the Golden quadrangle, Colorado: U.S. Geol. Survey Geol. Quad. Map GQ-103.

Waagé, K. M., 1955, Dakota group in northern Front Range foothills, Colorado: U.S. Geol. Survey Prof. Paper 274-B, p. 15-51.

Walker, G. W., 1963, Host rocks and their alteration as related to uranium, bearing veins in the United States: U.S Geol. Survey Prof. Paper 455-C.

Walker, G. W., and Adams, J. W., 1963, Mineralogy, internal structure and textural characteristics, and paragenesis of uranium-bearing veins in the United States: U.S. Geol. Survey Prof. Paper 455-D. 
Walker, G. W., and Osterwald, F. W., 1963, Classification and distribution of uranium-bearing veins in the United States: U.S. Geol. Survey Prof. Paper 455-A.

Wells, J. D., 1960, Petrography of radioactive Tertiary igneous rocks, Front Range mineral belt, Colorado: U.S. Geol. Survey Bull. 1032-E, p. 223-272 [1961].

Wells, J. D., and Harrison, J. E., 1954, Radioactivity reconnaissance of part of north-central Clear Creek County, Colorado: U.S. Geol. Survey Circ. 345, 9 p.

Wells, J. D., Sheridan, D. M., and Albee, A. L., 1961, Metamorphism and structural history of the Coal Creek area, Front Range, Colorado, in Short Papers in the geologic and hydrologie sciences: U.S. Geol. Survey Prof. Paper 424-C, art. 196, p. C127-C131.

1964, Relationship of the Precamtrian quartzite-schist sequence to the Idaho Springs Formation, Coal Creek, Front Range, Colorado: U.S. Geol. Survey Prof. Paper 454-O.

Wright, H. D., 1954, Mineralogy of a uraninite deposit at Caribou, Colorado: Econ. Geology, v. 49, no. 2, p. 129-174 



\section{INDEX}

[Italic page numbers indicate major references]

$\boldsymbol{\Lambda}$

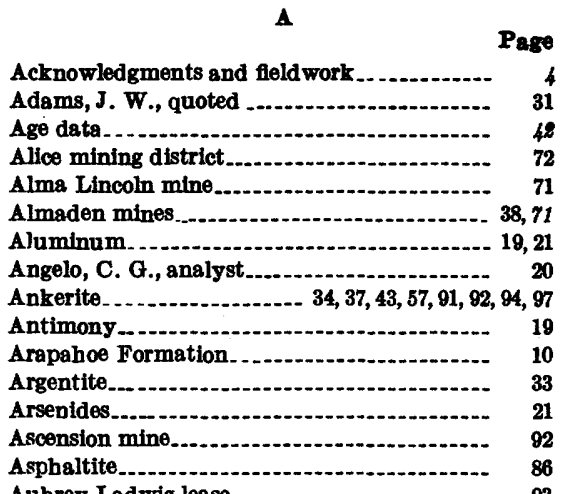

Aubrey Ladwig lease. Autunite.................... 18, 40, 57, 61, 71, 101, 105

Azurite 41,86

\section{B}

Baltimore Belle claim

Beltimore Belle pits.

Barite.

Barium

14,75

Barnett, P. R., analyst...................... 22

Base-metal sulfides. ............... 92

Bassetite. ................... 18, 61

Becquerelite.................................... 41, 101

Beryllinm

19

Billikin lode $38,41,101$

Bismuth.

$19,86,94$

Black Cloud mine

Black Knight fault. .......................... 101

Black Knight lode................. 38, 101

Blackhawk fault

Blackhawk Lode No. 2 claim................ 73

Blazing Star vein

Blue Jay mine

Blue Jay vein

Bonanza mine

Bonus mine.

Bornite

Bostonite porphyry

Bovlder County

Boulder County tungsten district. $\ldots \ldots$ 13, 14, 43, 44

Boulder Creek batholith

Boulder Creek Granite

Breccia.

Breccia reef faults. $8,63,72,74$

Breccla reefs

Breckenridge district

Buena mine
C

Page

Calcite. $33,91,92,94,97$

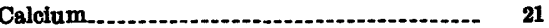

Caribou mine. ....................... 32, 36, 47, 54, 66

Carbonate minerals............ 14, 22, 75, 85, 92, 97, 101

Caribou shaft................................ 66

Caribou stock. . .

Caribou-Grand Island district................ 47, 54

Carlile Shale. . . . . . .

Carroll fault.......... 39

Carroll mine........ 73, 75

Carroll vein . .......................... 23, 39, 76

Central City district............. 4, 6, 12, 14, 15, 17, 19,

$24,25,38,36,40,41,42,43,46,73,75$ general geology .......................... 75

Cerargyrite_...

Cerite _........... 54

Chalcedony . . .......... 33, 62

Chalcocite............... 86, 91,94

Chalcopyrite................ 14, 21, 22, 29, 30, 33, 6S, 60,

$66,69,71,72,75,77,86,91,94,87,101$

Charlie adit. . ................................... 90

Chicago Creek mining district................ 5, 69

Chlorite........... 37, 62, 97

Chromium. . . ................. 19

Class 1 deposits................................ 54, 56

Class 2 deposits................................. 84,64

Class 3 deposits.......................... 54, 82

Classification of deposits......................

Clay minerals.................... 22, 37, 57

Clear Creek County........................ 69 other areas.

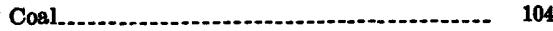

Cobalt . . . . .

Cochetopa district.............................. 43

Coffinite.......... 14, 17, 18, 22, 24, 25, 27, 28, 29, 30, 31, $34,35,56,57,59,60,71,82,85,91,97,105$ minor elements........................... 21 spectrochemica] analyses. . . .

Colorado mineral belt. . . . . ....................... 4

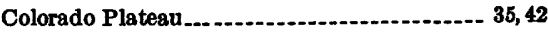

Colorado vein. . ............................. 91

Conklin, N. M., analyst....................... 20

Copper.......... 4, 13, 19, 21, 43, 44, 69, 72, 73, 75, 77, 101

Copper King mine.................... 7, 17, 21, 22, 30

Copper sulfides.................................. 40

Copper-lead-zinc ores.............. 43

Covellite. . . .

Cripple Creek

Cymoid curves. .

Cymold fractures................... 38

Cymoid loops. ............ 96 
Dakota Group

Damming fault $102,103,104$

Denver Formation.

Dumonite

\section{$\mathbf{E}$}

East Calhoun mines

East vein.

Eldora district.

Eldorado mine. . .

Elliot mine.

Emplectite.

Enargite

Eureka Gulch

\section{F}

Fair Day claim

Fajr Day mine.

$15,17,21,22,24,27,28,29$

$38,44,47,54,56,57,58,61$

Fall River area.

Fault breccias.

Fault systems, major

Faults. low-angle. northeastward-trending north-northeastward-trending northwestward-trending

Fieldwork and acknowledgments............. 4 Fluorite. Fluorspar deposits...................... 54, 56, 61 Fluorspar veins................................ 62

Folds.

Foothills mine................... 17, 21, 38, 94, 96,99

Foothills vein ............................. 86,97

Fork prospect. ............... 86

Four Corners mine ................ 15, 36, 102, 104

Fox Hills Sandstone......................... 9, 105

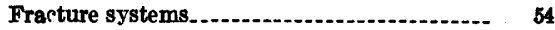

Freeland-Lamartine district................... $\quad 5,69$

Frelbergite.............

Front Range mineral belt.......... 4,

Future of region.

$7,12,13,14,23,45,54,73$

\section{a}

Galena $14,19,22,33,40,57,59$ $62,64,66,71,75,77,78 ; 86,91,94,97$

Galena-sphalerite veins

Gangue

Cenesis of uranium deposits

Geology, economic general.

German mine

German vein

Gersdorffte.

Gilpin County. other areas

Golconda mine............................ 31 Gold....... 4, 13, 23, 43, 54, 63, 64, 69, 72, 73, 75, 77, 101

Gold Age mine.

Gold Anchor mine........... 71, 78

47,54

Gold-bearing pyrite .......................... 43

Gold-bearing veins....................... 14, 42, 73

Gold deposits, pyritic.
Gold Hill district general features

Page 65

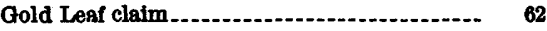
Gold telluride ores............. 13,43, 64, 61,62,75 Gold telluride veins..................... 14, 63, 64, 69

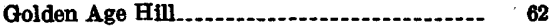
Golden Gate Canyon area_........ 39, 44, 82, 85, 92, 98 Golder-Passarale property..................... 78 Goldfields region................... 25, 37 Graneros Shale................................ 9 Grapevine mine................... 95, 89 Great Bear Lake . . ............. 25 Greenhorn Jimestone...................... 9

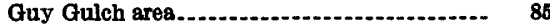

\section{H}

Hamilton, J. C., analyst........................ 20 Havens, R. G., analyst................. 20

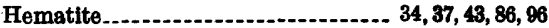
Fistory and production of uranium........ 5 Ho "meis er prospect ....................... 93 Hurricane Hill fault system.............. 16, 85, 92, 98 Hydropitchblende........................... 17

\section{I}

Idaho Springs and adjacent districts, general features.............................. 69

Idaho Springs mining district......... 4, 43, 69, 71, 75 Idaho Springs-Ralston shear zone............. 11

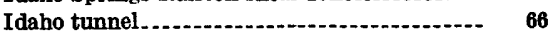
Idledale district. . ......... 7, 17, 38, 42, 44, 78, 82, 96,99 general features............................... 94

Illinois vein. ......... 80,91

nite

Ilsemanite .............. 60,103

Introduction. . . ...........................

Iron

Iron mine. . . . .

Iron oxides . . .

Iron-rich Precambrian metamorphic rocks.... 46

Jamestown distict-

amestown district. $7,14,15,17,22,27,36,38,44,47,54$ general features......................... 54

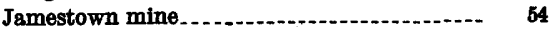

Jefferson County

other areas.

other mines ........ 98

Jelly Ro'l claim ... 78

Jo Reynolds mine. .

Joschimsthal

Jordisite............. 30

Junction Ranch fault._.

Justice Hill...................... 73

Kansas vein $\quad K$

Kaolinite............. 36

Kasolite_...... 18, 40, 76

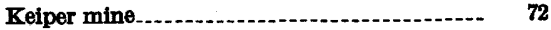

Kennedy Gulch.

Kirk mine............. 6, 19, 25, 73, 75, 76

Kirk vein. 
Laramide igneous sequence

Laramide intrusive igneous rocks............. 10,45

Laramide orogeny........................ 7, 10,85

Laramie Formation. . . .

Laramie Range

Lawson district ................... 19

Lawson-Dumont-Fall River district........... 5,69

Lead. .................... 4, 19, 23, 43, 44, 64, 66, 69, 73, 77

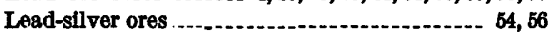

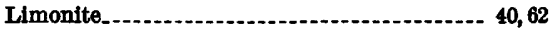

Little Annie m ne .............................. $\quad 19$

Localization of deposits

chemical controls............ 37, 39

structural controls .......................... 37,38

Lulu B claim . . .

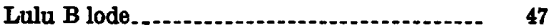

\section{$\mathbf{M}$}

Malachite

Manganese

Mann No. 1 mine. .................. 15, 36, 102, 104

Marcasite ............................ 35, 59, 86, 97, 105

Marshall Pass district......................... 43

Martha E tunnel.

Mary mine.......... 38, 71

Mena mine. ................ 21, 25, 42, 86, 93

Mena vein

Meta-autunite ......... 18, 03

Metamorphic rocks

Metatorbernite ............................ 18, 40,64

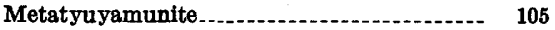

Miller group

Mineralogy of uranium deposits . ............ 17,43

Mines, description of principal........-.-... $\quad 47$

Minnesota adit........... 90

Molybdenite................................. 86

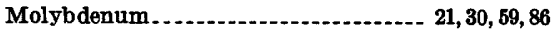

Montmorillonite

Morrison mine . . .

Mount Morrison Formation..........-_-_._. 94, 96

Mullions.

Nations Treasure mine

Native silver

Nebraska vein

Niccolite. $21,71,86,91,94$

Nickel.

Nigger Hill

Nigger shaft. -.. . .

Niobium

Niobrara Formation

North adit.

North Gilpin

North Star mine

North vein

\section{0}

Ohman mine

Old Leyden coal mine.

Ore deposits

Ore shoots

$15,60,86,103$

Ores, zonal arrangement

Page

Oxidation zones of uranium-bearing sulfide veins.

Oxidation zones of veins containing sparse sulfides

40

\section{$\mathbf{P}$}

Pallaoro lease

Paragenesis of uranium deposits .............. 24,60

Pararammelsbergite........................... 21,71

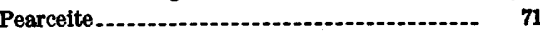

Phosphuranylite.

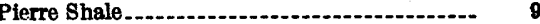

Pikes Peak Granite.

Pitchblende ....................... 6

$14,17,21,23,24,25,26,27,28,29,30$,

$31,32,34,35,37,40.42,46,54,59,60$, $66,68,69,71,72,75,76,77,85,91,92$, 93, 94, 97, 99, 101.

hard primary......... 41, 66, 76

hard unaltered.............................. 28

hydration .................................. 41

minor elements........... 18

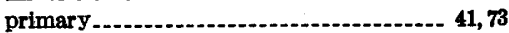

secondary ................................... 41 sootlike................. 28, 39, 40,41, 64, 66, 76, 97

spectrographic analyses...................... 20

textural forms.............................. 25

the term.......... 17

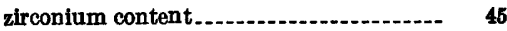

Pitchblende-bearing fault breccia............. 93

Pitchblende-bearing veins....................... 91

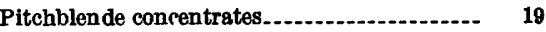

Porphyritic igneous rocks.................... 74

Porphrry Mountain

Potassic feldspar......... 34, 36, 37, 43, 85, 91, 92, 94, 97

Precambrian rocks.......................... 8

Production and history of uranium............ 6

Proustite........................................ 33, 71

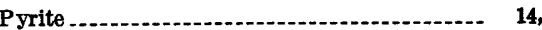

$21,22,23,27,28,29,32,33,34,35,36$,

$40,57,59,60,62,64,66,71,72,75,77$,

$85,91,92,93,94,97,99,101,103,105$.

Pyrite-quartz veins.

Pyritic gold ores

Pyritlc gold veins ................... 64

Pyritic veins. . ..................... 75

Pyrrhotite_............ 86

\section{Q}

Quartz

$21,22,32,33,34.35,36,37,43,57$, $59,60,62,64,67,72,77,85,91,92,94,97$

Quartz bostonite porphyry ................... 45 Quartz Hill................. 6, 15, 19, 24, 40, 73, 75, 76, 77

\section{$\mathbf{R}$}

Radioartive material ........................... 67, 78

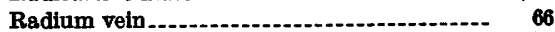

Ralston Buttes district...... 7, 16, 17, 19, 25, 34, 37, 38, $41,42,44,78,82,85,86,87,01,92,99$

Ralston Creek area..........................- 85

Ralston Creek mine .................... 87

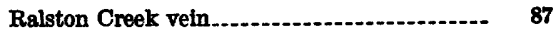

Rare-earth minerals. ........................... 15

Regional zoning relative to the mincral belt... 28 
Page

Rogers fault system

$16,85,90,94$

Rogers reef.

Ruby silver

\section{$\mathbf{8}$}

Bawmill Gulch

Schroeckingerite

Schwartzwalder mine

64

, $17,21,34,37,38,42$

Sedimentary rocks of Paleozoir, Mesozoic, and Cenozole age...

Serlcite.

30,36

Shirley mine

67

Siderite.

$21,31,33$

silver.

$4,19,23,43,44,63,64$

$66,69,71,72,75,77,86,101$

Silver-bearing pyrite $14,42,69,73$

Sllver-bearing veins.

Silver-lead veins.

73,75

Silver Hill

Silver Plume Granite..... 8, 11, 56, 58, 61, 62, 63, 67, 74

Sisk mine .............................. 47, 54,67

South adit.................................... 93, 94

South vein.................................. 72

Sphalerite ........... 14, 21, 22, 23, 29, 33, 40, 46, 59, 60,

$64,66,71,75,77,86,91,97$

- Stanlev mine

17,71

Steve level

Strontium

Structure of Precambrian rocks

Sulfide ore

Supergene alteration

Supergene solutions.

Supergene zone.

\section{$\mathbf{T}$}

Tallahassee Creek district.

Tallahassee district.

Target vein

Tennantite $69,71,72,75,77$

Tetrahedrite-tennantite $14,22,86,91,97$

Thallium

Thorium

Titanium

Torbernite

Tungsten.

Two Sisters mine

$10,11,17,45$

46

$18,40,61,62,63,64,71,76,78$

\section{$\mathbf{U}$}

Union Pacific deposit

Union Pacific prospect.

Upper adit.

Urad mine.

Uraniferous asphalt

Uraniferous breccia.

86,103

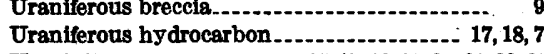
$15,17,18,22,30,31,33,35$

$42,64,66,67,67,69,82,103,104$ colloform variety

Uranium

$10,11,14,17,23,40,45,46$,

$54,66,67,73,75,77,82,99,108,104,105$
Uranium-Continued Page

equivalent................................ 15, 11

total output........... $5,56,78$

Uranium-bearing cosl....................... 105

Uranium-bearing fluorite veins.............. 22, 66

Uranium-bearing fluorite veins and breccias, class 1 deposits.

Uranium-bearing pegmatites ................. 15

Uranium-bearing sulfide veins............. 22, 36, 40

Uranium deposits. ................... 13, 14, 37, 44, 47

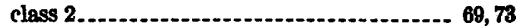

class 3 ..................... 85

localization................................. 86

Uranium minerals............................. 15, 17

carbonate . . . . .

hexavalent............... 41

primary .......................... 24, 25, 41, 46,60

secondary . . ....................... 22, 39, 85, 101

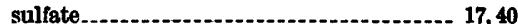

Urantum ore ............ 5, 6, 25, 30,40,47, 59, 96,153

Uranium production....................... 6,82

Uranium under oxidizing conditions........... 39

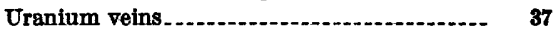

Uranophane.................. 18, 105

Uranothorite .................. 17, 22, 23, 56, 57

Uranous silicate . ................................ 17

Uranyl compounds.............................. 39

Uranyl hydroxide hydrates..................... 41

Uranyl ion solution stage....................... 41

Vanadium..........

Veins................................ 63, 64, 67, 72, 85, 99

epithermal. ............................... 24, 44

mesothermal............................... 24, 44

Veins In which uranium minerals are dominant, class 3 deposits.............. 24

Victory claim ................................... 62

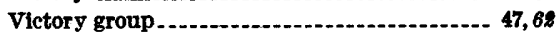

Vugs.

\section{W}

Walker, G. W., quoted.

Wallrocks and their alteration ............. $\$ 6$

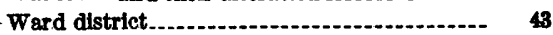

Washington vein......... 91

Willts Gulch ......................... 75

Wood gold mine..... 6, 19, 42, 73

Wood vein ...................................... 24

Wood-East Calhoun mines ................... 19

Wright lease........... 96

\section{$\mathbf{Y}$}

Young, E. J., analyst.................. 20

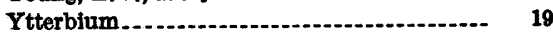

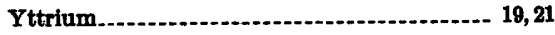

\section{$\mathbf{Z}$}

Zinc

$4,13,19,21,23,43,44,64,69,73,76$

Zirconium.

$10,19,21,45$

Zonal pattern 
The U.S. Geological Survey Library has cataloged this publication as follows:

\section{Sims, Paul Kibler 1918-}

Geology of uranium deposits in the Front Range, Colorado, by P. K. Sims and D. M. Sheridan. With sections by R. U. King [and others] Washington, U.S. Govt. Print. Off., 1964. $v, 113$ p. illus., maps (5 fold. in pocket) diagrs., tables. $24 \mathrm{~cm}$. (U.S. Geological Survey. Bulletin 1159)

Prepared partly on behalf of the U.S. Atomic Energy Commission. Bibliography : p. 106-111.

(Continued on next card)

\section{Sims, Paul Kibler 1918- Geology of uranium} deposits in the Front Range, Colorado. 1964. (Card 2)

1. Geology-Colorado-Front Range. 2. Uranium ores-ColoradoFront Range. 3. Mines and mineral resources-Colorado-Front Range. I. Sheridan, Douglas Maynard, 1921- joint author. II. Title. (Series) 
